\title{
Publishing \& the Book in Africa: A Literature Review for 2017
}

\author{
Hans M. Zell \\ hanszell@hanszell.co.uk \\ Copyright (C) Hans Zell Publishing Consultants 2018
}

This is the third in a series of annual reviews of select new literature in English that has appeared on the topic of publishing and the book sector in sub-Saharan Africa.

The previous annual literature reviews can be found as follows:

2016:

https://www.academia.edu/31441110/Publishing_and_the_Book_in_Africa_A_Literature_ Review_for_2016 (pre-print version)

Print/online version published in The African Book Publishing Record 43, no. 2 (May 2017): 120-

170. https://doi.org/10.1515/abpr-2017-0004

2015:

https://www.academia.edu/20432811/Publishing_and_the_Book_in_Africa_-

_A_Literature_Review_for_2015 (pre-print version)

Print/online version published in The African Book Publishing Record 42, no. 1 (March 2016):

11-37. https://doi.org/10.1515/abpr-2016-0003.

Extensively annotated and/or with abstracts, the present list brings together new literature published during the course of 2017, a total of 157 records. Also included are a small number of articles and other documents published in 2016 or earlier, and which have not hitherto been included in previous annual literature reviews or in the Publishing, Books E Reading in Sub-Saharan Africa online database (see also below). The literature review covers books, chapters in books and edited collections, journal articles, Internet documents and reports, theses and dissertations, interviews, audio/video recordings and podcasts, as well as a number of blog postings, with their posting dates indicated. Newspaper articles and stories are not generally included, unless of substantial length or of special significance.

Records are grouped under a range of regional/country and topic-specific headings. It should be noted that, for the most part, literature on particular topics, e.g. children's book publishing, digital publishing, educational and schoolbook publishing, publishing in African languages, reading culture and reading promotion, scholarly publishing, etc. is listed under topic/subject rather than country headings. For example, an article on developments in the digital book sector in Kenya will be listed in the topics sub-section entitled 'Digital media and electronic publishing' rather than in the country section for 
'Kenya'. However, in the absence of a country index it is possible to search for all countryspecific records by using the $\mathrm{Ctrl}+\mathrm{F}$ 'find' function in this document. For example, typing 'Kenya' in the search box will find any text/records (in titles of articles, blog postings and other documents, or if part of the annotations) containing the word 'Kenya'. The same function can also be used to search for names of authors.

Most journal articles published online are freely accessible, but a small number are behind a paywall and subscription based. For web documents and online journals the date the source was accessed is indicated [in square brackets].

If I have missed any articles/papers, books, theses, or other relevant documents on the topics covered by this literature review (and published or posted in 2017), I would be grateful if these could be brought to my attention. Please email details to hanszell@hanszell.co.uk, together with an electronic file of the document, or a link to it.

All these records, and many more, are scheduled to be integrated into the online database of Publishing, Books $\mathcal{E}$ Reading in Sub-Saharan Africa, which is currently in the process of migrating to a new hosting institution, Kwara State University Library in Nigeria (see also press release at http://www.hanszell.co.uk/Press\%20release.pdf). Unfortunately, due to a number of technical issues at KWASU relating to metadata mapping and software functionality, there have been serious delays in the migration of the database, but it is now hoped that the new hosts will be able to re-launch it during the early part of 2018, on a more dynamic, Drupal-based open source content management platform. The first batch of updates and over 500 entirely new records will then also be added to the database. For more information about the new database to be launched by Kwara State University Library, contact Teslim B. Balogun, Project Director, PBRSSA, teslim.balogun@kwasu.edu.ng.

This pre-print version uploaded on Academia.edu on 09 February 2018.

Print version to appear in The African Book Publishing Record

Volume 44, Issue 2, (May 2018) https://www.degruyter.com/view/j/abpr 


\section{Contents}

REFERENCE \& BIBLIOGRAPHY

GENERAL \& REGIONAL STUDIES 5

Africa: General studies/Book history in Africa 5

Regional studies: Africa, Francophone (articles in English only) 12

$\begin{array}{ll}\text { Regional studies: Africa, West } & 13\end{array}$

COUNTRY STUDIES

Note: most articles or blog postings on particular topics or areas of the book trade, for example publishing for children, publishing in African languages, copyright, scholarly publishing, etc. are classified under STUDIES BY TOPIC, see below.

$\begin{array}{ll}\text { Cameroon } & 14 \\ \text { Ethiopia } & 15 \\ \text { Ghana } & 15 \\ \text { Kenya } & 16 \\ \text { Lesotho } & 18 \\ \text { Liberia } & 19 \\ \text { Nigeria } & 19 \\ \text { South Africa } & 25 \\ \text { Tanzania } & 30 \\ \text { Uganda } & 32 \\ \text { Zambia } & 32 \\ \text { Zimbabwe } & 32\end{array}$

STUDIES BY TOPIC

Authors and publishers/Publishing of African writers and African literature

(in Africa and elsewhere)

Book and journals assistance and donation programmes 38

$\begin{array}{ll}\text { Book fairs and festivals } & 41\end{array}$

$\begin{array}{ll}\text { Book prizes and awards } & 42\end{array}$

Children's book publishing 43

Copyright and legal deposit/Authors' rights/Book piracy 45

Digital media and electronic publishing 46

Educational and school book publishing $\quad 50$

Intra-African book trade $\quad 52$

Journals and magazine publishing $\quad 52$

Open access publishing and licensing 56

$\begin{array}{ll}\text { Predatory publishing } & 60\end{array}$

$\begin{array}{ll}\text { Publishing in African languages } & 61\end{array}$

$\begin{array}{ll}\text { Reading culture and reading promotion } & 64\end{array}$

$\begin{array}{ll}\text { Scholarly publishing (General) } & 67\end{array}$

Women in African publishing/Publishing by and for women 76 


\section{REFERENCE \& BIBLIOGRAPHY}

Zell, Hans M. Publishing \& the Book in Africa: A Literature Review for 2016." The African Book Publishing Record 43, no. 2 (May 2017): 120-170. https://doi.org/10.1515/abpr-2017-0004 Pre-print online version (freely accessible) https://www.academia.edu/31441110/Publishing_and_the_Book_in_Africa_A_Literature_ Review_for_2016 [19/05/17]

The predecessor of the present list, this is the second in a series of annual reviews of select new literature in English that has appeared on the topic of publishing and the book sector in sub-Saharan Africa. Extensively annotated and/or with abstracts, it brings together new literature published during the course of 2016, a total of 164 records. The literature review covers books, chapters in books and edited collections, journal articles, Internet documents and reports, theses and dissertations, interviews, audio/video recordings and podcasts, as well as a number of blog postings, Records are grouped under a range of regional/country and topic-specific headings.

\section{GENERAL \& REGIONAL STUDIES}

\section{Africa: General studies/Book history in Africa}

Africa Writes 2017 How to Reach the Readers: Publishing in Africa. https://www.mixcloud.com/royafrisoc/africa-writes-2017-publishing-in-africa/ (Podcast, 1hr10mins) [06/11/17]

A panel/podcast from the Royal African Society's annual 'Africa Writes' event, held on 2 July 2017 at the British Library. The panellists were Louise Umutoni (Huza Books, Rwanda https://huzabooks.com/), Billy Kahora (Kwani? Trust, Kenya http://kwani.org/), Goretti Kyomuhendo (African Writers Trust, Uganda http://africanwriterstrust.org/) and Ruth Sorby of the Worldreader organization https://www.worldreader.org/, in conversation with Emma Shercliff. Panelists were asked to speak about the "realities of publishing on the continent", their business models, how they reach readers, what the readers want to read, and the many challenges they face. What innovative methods are publishers using to make sure readers across the continent can read work by African authors? Is the excitement of ereaders and digital distribution all it's cracked up to be? And considering factors like shifting donor economies and a rapidly expanding population of young people, what does the future of publishing look in different parts of Africa?

Alfredsson, Henrick Her Mission: To Bring African Books to a Global Audience. http://nai.uu.se/news/articles/2017/06/07/144445/index.xml (Posted 07 June 2017) [27/06/17] Another version also at http://www.readafricanbooks.com/opinions/her-mission-to-bringafrican-books-to-a-global-audience [05/08/17]

Mary Jay, former CEO of African Books Collective Limited http://www.africanbookscollective.com/ reflects on the prospects and challenges of the African book industries, and her involvement over the past three decades promoting the works of African authors and academic scholars to a global audience. Surprisingly, she says, "few are aware of the importance of encouraging and supporting African publishing, even in the academic world of the Global North. Today in many UK universities, and probably elsewhere in the world as well, you can take a degree or master's in African studies without 
reading a single book published in Africa." In many African countries and regions, like so many other sectors of the book market, has also been infected by corruption and unfair competition, in some cases caused by big and powerful actors from the Global North. Meantime overseas book donation programmes on a massive scale can have unintentionally negative consequences. In some cases when book aid organisations send large quantities of books, often textbooks for educational purposes, they unwittingly kill the market for regional or local publishers and writers. The donated books are almost without exception published outside of Africa, and written by non-African authors, Jay says. "It is vital that African children have access to books published from within their own cultures, books that relate to their own lives and experiences. It would be preferable for Northern donations to be in the form of budgets for purchase, rather than the expense of shipping container-loads of books, which are too often simply library or publisher overstocks."

\section{Bgoya, Walter Publishers, Authors and Africa's Cultural Development: Do the African Intelligentsia and the African States Care?}

http://www.readafricanbooks.com/opinions/publishers-authors-and-africa-s-culturaldevelopment [03/09/17]

The keynote address delivered by Tanzanian publisher Walter Bgoya at the 3rd East African Literature and Cultural Studies Conference, held in Dar es Salaam in August 2017. As a publisher who has been involved in the African book industries for forty-five years, he shares his thoughts about publishers and publishing, writers and writing, and their role in African cultural development; and thereafter reflects on this question: do the African intelligentsia and African state really care? He pays particular attention to the situation of textbook publishing in Tanzania, where conflicting approaches and interests about the development, control and delivery of educational books to schools in the country have been a feature of the Tanzania publishing industry from the very beginning. It has gone through the experience of state publishing (1966-1985), private sector publishing (1991-2012), and in 2014 it reverted yet again to state publishing. The country's Institute of Education (TIE) has been put in charge of all aspects and all levels of textbook publishing, including commissioning, manuscript development, through to production and distribution. However, there has been public uproar about the unacceptable quality of the books produced by TIE. Members of Parliament and the public, who had previously been vociferous in calling for a return to the state publishing model, are now silent and the government has not revealed the next steps to remedy the situation. According to Bgoya, a vast amount of money was squandered, millions of books were pulped, and school children have gone without textbooks. The pre-emptive policy change left publishers with published but unsold stocks and many manuscripts at different pre-printing stages. Meantime no redress to the publishers has been entertained.

In drawing attention to this ill-fated situation Bgoya says: "My intention is to explicate the effect that such policy insecurity can have on any publishing industry that relies heavily on textbooks, which is pretty much the situation in all African countries. The disruption of the process of building up human resources capacity: publishing managers, editors, typesetters, book designers, illustrators, book distributors and bookshops, will have a far reaching negative impact on developing a book and literary culture. And this is the experience in most countries, including South Africa, which has the most developed publishing industry in Sub-Saharan Africa." Given such a situation, can African publishing survive and prosper? 
"When the problem of publishers' dependence on winning textbook tenders is disconnected, the urgent question to ask is: why do our societies appear unable to support publishing industries that are not dependent for survival on supplying schoolbooks? Is there no interest in locally published works of fiction, children's books and trade books, including social science and humanities? Or is this simply a self-fulfilling projection that has been ingested and acted upon by publishers; so focussed on textbook publishing that they do not take the risk to see if they can survive and even thrive moderately without kow-towing to state officials in charge of education. Or even possibly that there is no sufficient research to validate the assumptions made about the prospects of independent publishing."

\section{Brouillette, Sarah On the African Literary Hustle.}

https://blindfieldjournal.com/2017/08/14/on-the-african-literary-hustle/ (Posted 14 August 2017) [24/10/17]

Sarah Brouillete's research interests include economic and political circumstances that underpin and influence the production, circulation and reception of contemporary literature and culture; and that includes African literature, and how that literature circulates in Western markets. In this long, provocative, and arguably somewhat contentious essay, she asserts that "the recent renaissance in African literature has had little do with development of viable literary readerships in Africa, and viably capitalized production facilities. The postindependence quest to develop literary readerships and publishing and printing trades faced massive hurdles; it was nearly stopped by IMF \& World Bank structural adjustment and trade liberalization in the 1990s, and has now been all but abandoned. The field of contemporary Anglophone African literature relies instead on private donors, mainly but not exclusively American, supporting a transnational coterie of editors, writers, prize judges, event organizers, and workshop instructors. The literary works that arise from this milieu of course tend to be targeted at British and American markets."

She then follows this with a short section entitled 'Aspects of the History of Literary Publishing in Africa', quoting from some of the recent literature. We have witnessed, Brouillette says, an African literary revival, or "literary hustle", and there is now a thriving African literary community across key cities. However, they are "a coterie, often working with donor support for their publications and workshops, and able to build upon the connections and synergies that exist within any small relatively wealthy group of cultural producers and consumers - journalists, musicians, academics, and so on. Writers who belong to this particular coterie are published abroad, supported by US creative writing and English department professorships, and by US- and UK-based literary agencies." As a result, "while there is a small readership in these urban centers, it isn't that important that there be local readers. These writers have bypassed the problem of the absent African reader. There is donor funding to support the activity of writing, to award prizes to authors, and to facilitate access to US and other foreign markets."

Brouillette argues that it is fair to claim that the writing that emerges from this scene is Western-facing - targeted primarily at British and American markets, but that one could make the point with greater precision: "The situation is one of donor-supported funding of networks of writers who are more dependent on each other as cultural brokers, on international donors, and on foreign markets, than they are on the existence of a local readership for literary works." She concludes: "Today we naturally witness a decline in 
material and affective supports for the acquisition of the literary disposition, and so find wrapped up together - in a classic story of deprivation and concentration of wealth - the declining interest in university English, the industry's concern about how to secure new readerships, the reliance on donor funding, the rise of festivals as money-making events, the close coteries, the prestige events, the posh bookstores, the powerful agencies, and the prizing. Signs of concentrated vigour evince health and decline all at once."

Note: see also the study by Doreen Strauhs African Literary NGOs. Power, Politics and Participation in this section.

Edoro, Ainehi Africa's Changing Literary Scene.

http://panafricannews.blogspot.co.uk/2017/10/africas-changing-literary-sceneoctober.html (Posted 22 October 2017) [30/10/17]

Today we are witnessing the emergence of an African literary market, and small independent publishers have sprouted all over the continent. But there's a catch the author says: "This industry is emerging at one of the most difficult times in global publishing. Aside from grappling with the issues everyone else is facing, African publishers have problems of their own. First, Africa lacks a strong tradition or infrastructure for publishing. Second, the $\$ 14$ it costs to buy a Penguin Classic is what many Africans earn in a week. Finally, within the continent, African literature has to compete in a media space monopolised by Nollywood and the thriving pop music industry." Moreover, unlike publishers in the West who can depend on library sales and the bookstore circuit, "the African publisher depends solely on an extremely volatile and unregulated market run by daredevil pirates and colluding customers looking for a cheap buy." So how can African publishers leverage what is still an unorthodox reading culture to establish a functional literary market? The contemporary audience for African literature, Bibi Bakare-Yusuf of Ankara Press (an imprint of Cassava Republic Press, publishing romantic fiction) https://www.ankarapress.com/ explains, is more discerning: "They make more demands on their writers. They expect more. They don't expect to be patronised. They feel like I can choose, I don't have to be bogged down reading African literature if I don't want to. They don't feel a sense of anxiety about their taste as they may have done in the past."

Hans Zell Publishing Links [to organizations and associations supportive of African publishing].

http://www.hanszell.co.uk/links.htm [12/01/18]

An extensive links section, constantly updated and expanded, to the websites - and Facebook pages, where available - of organizations (other than publishers), groups, and associations that are supportive of book and journal publishing, the 'book chain', and reading promotion in sub-Saharan Africa. A number of dealers and suppliers of Africanpublished books are also included, as are links to some of the major (Pan-African) book prizes and awards, book fairs, and other book promotional events. Over 130 links as at January 2018.

Kendemeh, Emmanuel Africa: Economic Growth - Africans Want Publishing Industry Key Pillar.

http://allafrica.com/stories/201711230219.html (Posted 23 November 2017) [25/11/17]

Reports (based on a news story in the Cameroon Tribune) about the 'High Level Regional Conference: The Publishing Industry in Africa and its Role in Education and Economic 
Growth', held in Yaoundé, Cameroon, November 22-23, 2017. Organized by the World Intellectual Property Organization (WIPO) and hosted by the Ministry of Arts and Culture of the Republic of Cameroon, it was reportedly attended by over 150 delegates from more than 40 African countries. The Director General of the World Intellectual Property Rights Organisation, Francis Gurry, in a video statement, is quoted as saying the development of the publishing industry in Africa was vital considering that the continent had the fastest growing youth population that will soon make Africa the centre of human resources. African governments, the report states, "are resolutely determined to get the publishing industry one of the main pillars of the continent's economic growth by putting in place actions for the public/private partnerships in order to get in Africa good benchmarks and good practices on which to build." Fine words, but which will probably have a ring of déjà$\mathrm{vu}$ for most of those active in the book industries in Africa today, who have sought more positive action from their governments to support indigenous publishing, for three or four decades or more, but with very little evidence of tangible support actually materializing thus far.

Note: WIPO has a link to the meeting at its website at http://www.wipo.int/meetings/en/details.jsp?meeting_id=45806, but at the time of going to press (February 2018), no details of papers presented, a conference report, or action plan are available.

\section{The New Publishing Standard-Africa}

http://www.thenewpublishingstandard.com/category/africa/ [20/01/18]

Edited by Mark Williams, this is a new global publishing industry e-magazine launched in September 2017, whose agenda "is to look at the publishing industry globally and holistically and to fully explore the Global New Renaissance we are all witnesses to and participants in." It has included a number of short postings and news stories on the African book industries, as well as other items of interest to the African book and writing professions, which have included the following:

\section{Storymoja - A Book in Every Hand.}

http://www.thenewpublishingstandard.com/storymoja-a-book-in-every-hand/ (Posted 06 November 2017)

About Storymoja http://storymojaafrica.co.ke/, formed by a collective of writers "who are committed to publishing contemporary East African writing of world-class standard", and which has now become a powerful force in East African publishing, issuing adult titles under the Storymoja imprint, and more than one hundred children's books under the Storyhippo imprint, as well as marketing and distributing books on behalf of other publishers and individuals.

\section{Micro-Aggregators in Africa Rise to Meet Growing Demand from Authors.} http://www.thenewpublishingstandard.com/micro-aggregators-in-africa-rise-tomeet-growing-demand-from-authors/ (Posted 11 November 2017)

Takes a look at the rapid growth of self-publishing and the activities of a microaggregator in Kenya, Mystery Publishers https://mysterypublisherslimited.com/. (See also an interview with its Publisher and author Vincent dePaul in this Nation story http://www.nation.co.ke/lifestyle/artculture/Publisher-and-author-Vincent-dePaul/1954194-4178414-9ujr7k/index.html) 
Yaoundé Conference - Analogue Thinking in a Digital Age. African Publishers Needs to Embrace Digital, not Re-invent First World Battles.

http://www.thenewpublishingstandard.com/yaounde-conference-analogue-

thinking-in-a-digital-age-african-publishers-needs-to-embrace-digital-not-re-inventfirst-world-battles/ (Posted 26 November 2017)

On the 'High Level Regional Conference: The Publishing Industry in Africa and its Role in Education and Economic Growth', held in Yaoundé, November 22-23, 2017, and hosted by the World Intellectual Property Organization (WIPO).

Social Media and Instagram are Making Books Sexy Again - in Nigeria. http://www.thenewpublishingstandard.com/social-media-and-instagram-aremaking-books-sexy-again-in-nigeria/ (Posted 24 November 2017)

On the activities of Nigerian publisher Cassava Republic Press, and an African literary scene "that is not just vibrant, but far-reaching. African authors are getting published in the US, UK and beyond, not by western gatekeepers buying the rights to selected treasures, but by African publishers publishing abroad for themselves."

Nyariki, Lily, with Lisa Krolak A Case for National Book and Reading Policies for Africa in the Advent of the Digital Revolution. An Advocacy Policy Paper for the Association for the Development of Education in Africa (ADEA): Working Group on Books and Learning Materials (WGBLM). Hamburg: UNESCO Institute for Lifelong Learning, 2016. 14 pp.

https://www.academia.edu/33539329/A_CASE_FOR_NATIONAL_BOOK_AND_READIN G_POLICIES_FOR_AFRICA_IN_THE_ADVENT_OF_THE_DIGITAL_REVOLUTION [24/06/17]

UNESCO and other organizations have repeatedly stressed over the years that, in order to ensure that book development is integrated in overall national development planning, the establishment of national book development councils is an essential requirement to guide national book policies; to serve as an intermediary between the book professions and the government, and to provide coordination between the different players in the book sector. As the authors of this policy paper note, national book development councils (or similar bodies) exist, or have existed, in several African countries, albeit "with varying degree of success." Several of them are currently dormant, or have shut down operations altogether. It could be argued that the main reason for this is that their funding has always been based either on government support, or dependent on continuing financial aid from donor organizations; and when the funding came to an end activities ceased. This advocacy document is a plea for their revival. In their conclusions the authors state "national book and reading policies are at the core of educational quality, literacy development, lifelong learning, and sustainable development. Africa needs to position itself to achieve the UN SDGs, and its own set of targets as stipulated in Agenda 2063 and CESA 2016-25 if it is to catch up with the rest of the world. All African countries owe it to themselves to formulate their book and reading policies and enact National Book and Reading Councils (NBRCs)." 
Stranger-Johannessen, Espen Africa Language and Literacy. A Landscape Review of Language and Literacy Research in African Contexts. Ottawa: CODE (Guiding Literacy Practice: Context Matters), 2017. 128 pp.

https://code.ngo/sites/default/files/code-africa-language-and-literacy-report-aug2017web.pdf [04/10/17]

This wide-ranging and important study addresses key issues based on recent research on language and literacy education in the African context, including teacher education, and outlines key findings and recommendations for research and practice based on a review of the literature. It also includes a discussion (sub-section 3.3) about 'Publishing in African Languages'. Part I of the report reviews focal areas of research and is based on academic articles and reports. Part II presents case studies of policies and teacher education, with a focus on 21st century skills, from six countries associated with CODE's work in Africa: Ethiopia, Ghana, Kenya, Liberia, Sierra Leone, and Tanzania. These case studies provide insight into the key issues discussed in Part I of the report.

In a section entitled 'Literacy Materials and Publishing', the report states "Print literacy materials, such as textbooks and storybooks, are key to helping students develop high levels of literacy. Yet there are often few textbooks and storybooks in African schools, particularly in African languages. Increasing the number of books available to students is important, but teachers' use of textbooks and storybooks in the classroom is also key, as making books available does not necessarily mean they will be utilized effectively. The publishing industry faces challenges from low demand and import of books from abroad." Publishing in African languages is only financially viable if there is a market for those books, either in the form of government guarantees or incentives, or other ways in which publishers can be confident that there is a market for their books.

Among the report's recommendations for research are:

(i) Research how to support teachers in using textbooks and storybooks: "Providing storybooks or textbooks does not always mean that these are read or used in effective ways. Research should explore and guide effective use of literacy materials in ways that are conducive to learning. Building on existing practices, such as shared choral reading, and retelling stories, are starting points that research should investigate further."

(ii) Research how textbooks and storybooks can promote gender equality: "The recent literature on African textbooks describes a tendency for textbooks to promote gender equality, but sometimes at odds with traditional gender norms. More research is required to learn how gender equality can be promoted while reflecting contemporary African societies, such as through the development or adaption of textbooks and storybooks, and reception studies of these new materials."

On the aspect of ICT and digital resources, the report says that ICT is often seen as a promising contribution to education in Africa and elsewhere, but there are high costs and technical and implementation challenges associated with introducing digital devices to schools. "ICT is more than devices for end-users, however. Open educational resources are important for sharing and creating materials, particularly in African languages." 
Strauhs, Doreen African Literary NGOs. Power, Politics and Participation. Basingstoke: Palgrave Macmillan, 2013. 243 pp.

This meticulously-documented and extensive study introduces a newly coined term literary NGO (LINGO), to describe "a distinct model for Anglophone African creative writing and cultural politics." The book "explores the mode by which contemporary Kenyan and Ugandan writers interact with the world of literary production and the socio-cultural as well as socio-political dynamics of their societies through literary activities on the basis of locally established writers' associations." To illustrate this relatively new phenomenon the author focuses on the activities - and evaluating its publishing output - of two such LINGOs: FEMWRITE. The Uganda Women Writers Association https://femrite.org/, and the Kwani Trust in Kenya http://kwani.org/, both of which support literary talent, events, competitions, and publishing in the non-profit sector. The book also includes a discussion of earlier LINGOs such as Transition magazine, the Chemchemi Creative Centre in Nairobi, and the Mbari Club in Ibadan, and is supported by a range of interviews with writers, academics, civil society activists, filmmakers and journalists recorded between 2006 and 2011. In her concluding chapter Strauhs says "African LINGOs, I believe, are not only sites for political and socio-cultural interventions, but breeding grounds for literary creativity and upcoming writers", and looks at possible future scenarios of the African LINGO in the twenty-first century.

Note: see also a review article of this book at Africa Book Link Fall 2017: Eastern Africa

http://mailchi.mp/d7baee9aba49/africa-book-link-fall-2017-eastern-africa-1488725?e=4387beb24d\#Writing

Williams, Olatoun Interview: Hans Zell.

http://www.bordersliteratureonline.net/hanszellinterview.html [01/09/17]

Also at https://www.academia.edu/34181016/Interview_with_Hans_M._Zell

Hans Zell in conversation with Olatoun Williams of Borders-Literature for all Nations http://www.bordersliteratureonline.net/index.html, a new Nigerian forum and book review media platform set up to encourage a lively reading culture in Nigeria and Africa, and promote the reading of African books worldwide. In a wide-ranging interview he talks about this engagement with publishing and the book in Africa over a period of over four decades, as well as answering questions about the Hans Zell Publishers imprint, the Noma Award for Publishing in Africa, author-publisher interaction in Africa, the new boom in selfpublishing, and conveys his views on the potential negative consequences on the African book industries of the activities of overseas book donation programmes, shipping millions of free books to Africa every year.

Regional studies: Africa, Francophone (articles in English only)

Bush, Ruth "Publishing Francophone African Literature in Translations: Towards a Relational Accounts of Postcolonial Book History." In Intimate Enemies: Translation in Francophone Contexts, edited by Kathryn Batchelor and Claire Bisdorff. Liverpool: Liverpool University Press (Francophone Postcolonial Studies, 4), 2013, 46-68.

Online version published as "African Literature in French and the Heinemann African Writers Series: Towards a Relational Account of Postcolonial Book History." https://www.academia.edu/15839407/African_literature_in_French_and_the_Heinemann_ African_Writers_Series_towards_a_relational_account_of_postcolonial_book_history [11/08/17] 
In charting the publishing history and translation of Cheikh Hamidou Kane's classic text L'Aventure ambiguë (Ambigous Adventure in its English translation), Ruth Bush seeks to show that the process of publishing English translations of francophone African writing "is bound up with the instrumental, and sometimes vexed, works of the translator of post-colonial texts." This interesting case study of early publishing strategies for 'African literatures' in English and French is based on archival research, interviews with the author and his publishers (in the UK, France, the US, and Nigeria), and printed and digital paratext. While Kane's text was first written as an autobiographical diary not intended for publication, Bush demonstrates that editors and advisors at the publishers "selected and packaged the text on the basis of their target readership." In her conclusion she states: "The status of translation and translators in this diagnosis of authors' performativity in the 'foreign' literary marketplace is unclear. Its insular model, binding the writer to a role as 'African writer and social commentator' in a specified local 'community', whether defined spatially or linguistically, now seems outdated."

\section{Snaije, Olivia Bigger Presence of Francophone African and Haitian Publishers in Frankfurt. \\ https://publishingperspectives.com/2017/10/dedicated-frankfurt-stand-francophone- african-haitian-publishers/ (Posted 12 October 2017) [19/10/17]}

France was the Frankfurt Book Fair's guest of honour in 2017, but also chose to highlight francophone authors as well as publishers from countries other than France. In an initiative organized by the International Bureau of French Publishing (BIEF), 20 publishers from Benin, Cameroon, Congo, Côte d'Ivoire, Gabon, Guinea, Haiti, Madagascar, Mauritius, Niger, Rwanda, Senegal, and Togo, were chosen to come to the Fair and to be part of a collective stand. Head of BIEF Pierre Myszkowski is quoted as saying that they represent "a production that deserves to be better known and recognized," adding "that he hoped that French publishers would become more interested in the books these francophone publishers have to offer, but also that francophone publishers might have access to authors from their countries that are published in France."

\section{Regional studies: Africa, West}

Ofori-Mensah, Akoss Conversations on Book Development in West Africa. http://www.readafricanbooks.com/opinions/conversations-on-book-development-inwest-africa

Akoss Ofori-Mensah of Sub-Saharan Publishers in Accra http://www.subsaharanpublishers.com/ is a well-known Ghanaian publisher specializing in African picture-story books for children, as well as publishing in the areas of African literature, gender studies, books on the environment, and a range of other scholarly books. In this insightful interview she talks about issues such as production quality of African-published books, donor and government support for literary and educational initiatives in Africa and the key players involved, buying and selling rights for her distinguished children's list and her notable successes in this area, as well as offering her thoughts on the rapidly changing publishing environment in the provision of teaching and learning materials (TMLS) in Africa and elsewhere. 
On the topic of digital media she says the development in new technologies vis à vis teaching and learning materials in Sub-Saharan Africa cannot be overlooked. However, some content might interest learners and teachers, while other content may not. "Although digital books and TLMS may eventually replace printed books, it is likely to be a gradual process." Moreover, "the choices are neither simple nor cost efficient, and there is perhaps no viable substitute for the traditional book, at least for the moment. Over the next decade or two, the most cost-effective approach may be a combination of printed materials and digital TLMS, especially for the teaching of science." In addition to infrastructural problems such erratic electricity supply, especially in rural areas, "the expense involved in the digital migration vis à vis the traditional book must also be considered. The cost of computers, tablets, phones, etc. In addition the cost of set-up should be compared with the cost of funding print runs and distribution to decide which is more cost effective. ... Elementary school teachers will also have to be ICT literate to be able to teach digital TLMs. That is another huge investment required in teacher training. ... I believe that the book as we know it will stay with us for many generations to come. You can go to bed with your book: when you fall asleep it falls down on the bed or on the floor. When you wake up it is still there, intact. You cannot do that with your computer."

\section{COUNTRY STUDIES}

Note: most articles or blog postings on particular topics or areas of the book trade, for example publishing for children, publishing in African languages, copyright, scholarly publishing, etc. are classified under STUDIES BY TOPIC, see p. 33.

\section{Cameroon}

Kitchen, Stephanie Interview with Francis Nyamnjoh, Langaa RPCIG, Cameroon. http://www.readafricanbooks.com/opinions/interview-with-francis-nyamnjoh (Posted 12 September 2017) [15/10/17]

Also at http://www.langaa-rpcig.net/+Interview-with-Francis-Nyamnjoh+.html

The mission of the Langaa Research and Publishing Common Initiative Group (Langaa RPCIG) http://www.langaa-rpcig.net/ is to contribute to the cultural development and renaissance of Africa. This is achieved by conducting research, providing training in research and writing, and publishing and promoting African scholarship and creative writing. The not-for-profit Langaa is supported by founding members and other contributors, financial grants, and efforts of volunteers. Located in Bamenda and Buea in Cameroon (although its members and volunteers operate from different parts of the world) it has thus far published over 500 titles, primarily on Cameroon, but also a wide variety of critical perspectives and studies on other African countries. In this interview with the head of the organization, Francis Nyamnjoh, he describes Langaa's commissioning strategy and how they market and distribute their books within Africa and internationally, Langaa's readership worldwide, their writing workshop programmes, what they see as their most important challenges, and what does he think is needed to strengthen research, publishing and distribution systems for general and academic publishers in the African continent? "We need to be curious and ask questions. We need to read and write. We need to encourage reading and writing. We need to promote Langaa, a desire for knowledge. We need to value knowledge generation in Africa and from African perspectives. We need to support African publishers." 
Note: For more information about Langaa see also this blog post by Francis B Nyamnjoh and Kathryn Toure

Desire for Knowledge - Langaa and Publishing in Africa http://www.langaa-rpcig.net/+Desire-for-

knowledge-Langaa-and+.html (Posted 24 September 2017) [15/10/17]

\section{Ethiopia}

Ashanafi, Neamin Reading the Book Market.

https://www.thereporterethiopia.com/content/reading-book-market (Posted 15 August 2017) [30/09/17]

These days, the author writes, "everywhere you go to in Addis, it seems that books are easily available. It is also a common sight to have people carrying around books on the roads and selling them to people sitting in cars, cafes' or to the pedestrians." This is a relatively new phenomenon that has taken over the city, as years ago "the book market and readership was not widespread like it is today and members of this generation were severely criticized by the older ones for not reading." But the issue this time around is not so much the number of readers, but the lack of quality - especially in terms of design, editing and proof-reading - in many of the books published recently, as well as the absence of an organized institution that works towards improving the quality of books. Apart from this, Ashanafi says, there is also another factor that contributes to the problem associated with the issue of quality: there are still only a few publishers in the country and the publishing sector remains at an infant stage, which brings different challenges for writers, many of whom have had to resort to self-publish their works, thus not benefiting from any book professional input.

Note: for a useful listing of bookshops in Addis see these Facebook pages

https://www.facebook.com/search/105822396124729/places-in/197048876974331/places/intersect/

https://www.facebook.com/search/top/?q=book\%20stores\%20in\%20addis\%20ababa\%20ethiopia

Workayehu, Mahlet Ethiopia: Mobile Booksellers Keep Addis Reading.

http://allafrica.com/stories/201701100645.html (Posted 10 January 2017) [15/02/17]

Another version also in https://publishingperspectives.com/2017/01/addis-ababa-ethiopiastreet-book-vendors/

In Addis Ababa reading books has become more common for people in all walks of life, and the people credited for expanding the readership of books are the mobile vendors. In an article first published in Addis Fortune, Workayehu reports that these vendors "walk around with books in their hands stacked all the way up to their neck, approaching any and everyone to buy a book of them." He estimates that there may be as many as 1,000 of these vendors on the streets, and describes how they get their books and what are the most popular titles; from which it emerges that most readers in Ethiopia are interested in reading books that revolve around politics, or iconic novels.

\section{Ghana}

Ghana Book News. A Newsletter of the Ghana Book Publishers Association 2016- Twice yearly [?] ISSN 08552320 Print and online

Edited by Agatha Akonor-Mills

Editorial address: Ghana Book Publishers Association, Bureau of Ghana Languages Building, Kawukudi Junction, Accra

Postal address: PO Box LT 471, Laterbiokorshie, Accra, Ghana 
Email: info@ghanabookpublishers.org or ghanabookpubs@yahoo.com

Two issues published to date:

http://ghanabookpublishers.org/downloads/gbpa_newsletter_1.pdf [17/11/17]

http://ghanabookpublishers.org/downloads/gbpa_newsletter_2.pdf [17/11/17]

An informative new publication from the Ghana Book Publishers Association http://ghanabookpublishers.org/ carrying news about the activities of the Association, reports about the annual Ghana International Book Fair http://www.ghanabookfair.com/, and other book promotional events. It also includes short contributions about book industry workshops and training for book professionals, reading programmes, copyright issues, the need for high standards of professionalism in book production, and more.

Buckle, Carollann Efua The Publishing Industry in Ghana: Ways to Promote Authors and Writing.

https://air.ashesi.edu.gh/bitstream/handle/20.500.11988/318/Buckle_Carollann_2017_BA_T hesis.pdf?sequence $=\mathbf{1}[28 / 12 / 17]$

Accra: Ashesi University College, 2017. BA thesis (Department of Business Administration). $58 \mathrm{pp}$.

In recent years the amount and quality of writing coming out of Ghana has been in sharp decline, the author claims. The cost of printing high quality books in the country, an overconcentration on the publication of textbooks, taxes imposed on the materials needed in the manufacturing of high quality publications, a low reading culture, ineffective marketing of locally published books, and authors failing to actively engage with their readers, are among the reasons for this decline. The objectives of this undergraduate thesis "was to explore the modes through which novels are promoted outside Ghana, how novels are promoted Ghana, and to give recommendations on how to better promote authors and creative writing in Ghana."

\section{Kenya}

Abrams, Dennis Kenya Publishers and Copyright Board Complain of Textbook Piracy. https://publishingperspectives.com/2017/04/kenya-publishers-textbook-piracy/ (Posted 12 April 2017) [24/06/17/]

According to reports in Kenya's Standard Digital newspaper (March 27, 2017), a raid recently conducted under the auspices of the Kenya Publishers Association http://kenyapublishers.org/ and the Kenya Copyright Board http://www.copyright.go.ke/ has unearthed a multi-million-shilling school textbook piracy racket, amidst allegations that rogue head teachers are colluding with hawkers to rob textbooks from public schools. The article depicts two routes used by this kind of operation: In one "brokers ... rope in school head teachers, who without following laid-down procurement laws, give them tenders to supply books. [The brokers] then link up with book pirates who operate backstreet printing firms which quickly print the books and directly-supply them to schools." In another racket involving textbooks "pirates, brokers, teachers and hawkers all work together to stage school break-ins, steal books to sell on the streets to unsuspecting buyers." 
Dahir, Abdi Latif The Online Bookstores Pushing for More Kenyans to Read Books by African Authors.

https://qz.com/905604/the-online-bookstores-pushing-for-more-kenyans-to-read-booksby-africans-authors/ (Posted 09 February 2017) [27/02/17]

Short profiles of the activities of a number of Kenyan online bookstores and e-book distributors: Magunga Bookstore https://www.books.magunga.com/ (which exclusively stocks books by and about African writers), the recently founded Ides of March Bookstore https://www.facebook.com/Ides-of-March-Bookstore-169890883436456/, and the e-Kitabu platform http://www.ekitabu.com/, that claims to offer a global repository of over 500,000 ebooks that allows users in 900 schools in Kenya to access them on desktop computers, tablets and Android phones, including titles in Kiswahili, Luo, Kikuyu, and Somali.

Kitchen, Stephanie Vita Books: Publishing Against Imperialism: Interview with Shiraz Durrani and Kimani Waweru.

http://www.readafricanbooks.com/opinions/vita-books-publishing-against-imperialism $[11 / 12 / 17]$

Vita Books (now distributed worldwide by African Books Collective) was established as a progressive/radical publisher over 30 years ago, moving from London to Kenya in 2016. Since its move it has continued to publish material meeting its principal aim of making progressive, alternative ideas and experiences available to working people. In this long but interesting and insightful conversation with Stephanie Kitchen of the International African Institute, Shiraz Durrani and Kimani Waweru talk about their most notable achievements over the years, their network of authors and activists and the range of their list; their views on general non-fiction publishing in Kenya (i.e. as distinct from school textbook publishing), the audience and readership of their books, as well as providing some examples of progressive book and library initiatives in Kenya in times past. Durrani says "Vita Books is not a traditional publisher but an activist organisation involved in progressive information, communication and publishing activities in the interest, not of profit, but of a free flow of relevant, alternative information for social and political transformation in the 'neo-colonised' world."

On another topic, on the frequetly non-existent library book acquisitions budgets in several sub-Saharan African countries, where many libraries have become dependent on a culture of (usually Northern) book donations, and the negative effect of this situation on autonomous publishing, Durrani and Waweru state: "The neoliberal policies pushed onto Africa by the WTO, World Bank and IMF have had the result of strangling educational and public libraries, turning them into beggars for crumbs from overseas. Their independence is limited and the content of what is published locally also reflects the needs of corporations, not the needs of working people. Bookselling, publishers and libraries in Kenya suffer from artificial controls on demand for books, driven by government policies such as the $16 \%$ tax [VAT] on books, restrictions on recommended books in curricula, and restricting diversity in the contents of books. In order to enforce such restrictive practices, the government then restricts funding to school, public and academic libraries thereby creating an artificial vacuum in book sales and availability. And yet, it is obvious if one visits public and academic libraries or even looks at street booksellers, that there is a great hunger for books in general, and particularly for content that reflects more relevant and alternative views and experiences." 
Presto, Greg In Africa, Locally Produced Comic Books are Starting to Catch on. https://www.marketplace.org/2017/02/20/world/africa-locally-produced-comic-books-arestarting-catch (Posted 20 February 2017) [24/06/17]

Many home-grown comics are being created in Africa, where locally produced comics are catching on. "They look just as slick as any American comic, but these stories aren't an easy sell to traditional African publishers." Many artists self-publish runs of 200 to 500 copies, but they still need a place to sell them, and this short article reports about new avenues of distribution, on mobiles and other platforms, and profiles a number of the artists in Kenya creating some of these comics.

\section{Tusome Early Grade Reading Activity}

Ngunjiri, Joseph, and Rose Wanjiku Kenyan Publishers Protest as US Firm Gets Books Monopoly for Lower Primary.

http://www.nation.co.ke/lifestyle/weekend/Kenyan-publishers-protest-as-US-firm-getsbooks-monopoly/1220-3881810-glwjtmz/index.html (Posted April 7 2017)

Sigei, Julius Ministry's One-Textbook Policy Kicks up a Storm.

http://www.nation.co.ke/news/education/Ministry-s-one-textbook-policy-kicks-up-a-

storm/2643604-4108038-yo9anb/index.html (Posted 22 September 2017)

Sigei, Julius New Textbook Policy Elicits Sharp Criticism.

http://www.nation.co.ke/news/education/New-textbook-policy-elicits-sharp-

criticism/2643604-4109544-13bt4q1z/index.html (Posted 24 September 2017)

The Tusome ("Let's Read" in Kiswahili) Early Grade Reading Activity is a partnership launched in 2015 between USAID and the Kenyan Ministry of Education, Science, and Technology (MOEST). Tusome, now being implemented through Ministry systems in every primary school in the country, is designed to improve the reading skills of 5.4 million pupils. The five-year programme is being implemented by the Research Triangle Institute (RTI) https://www.rti.org/ through its Africa regional office in Nairobi. See also https://www.usaid.gov/sites/default/files/documents/1860/Tusome $\% 20 \% 20$ Factsheet $\% 2020$ 16.pdf.

As set out in a number of reports in Kenya's leading newspaper the Daily Nation, the programme has reportedly created a great deal of apprehension among stakeholders in Kenya, notably private sector publishers who accuse the government of locking them out from producing books for core curriculum subjects. Another concern relates to the government's new textbook policy that limits schools to buy only one textbook per subject. Publishers are required to prepare manuscripts for select subjects, which are thereafter to be submitted to the Kenya Institute of Curriculum Development for vetting and approval. However, unlike in the past, only one textbook that scores highly will be recommended for use in schools, the rest relegated and designated as merely supplementary course books.

\section{Lesotho}

Segoete, Lineo Ba re e ne re: Building a Community of Writers and Readers in Lesotho. https://africainwords.com/2017/05/22/ba-re-e-ne-re-building-a-community-of-writers-andreaders-in-lesotho/ (Posted 22 May 2017) [01/07/17]

Lineo Segoete, Programming Director at Ba re e ne re https://bareenere.com/ (the name comes from a phrase used to begin folktales in Sesotho) reports about a new initiative to 
promote a culture of reading and writing in Lesotho. Activities include the organization of an annual literary festival and writing workshop, a national spelling bee competition, production of a poetry video series, an innovative Sesotho dictionary project, and publication of an anthology of short stories written in Basotho called Likheleke tsa puo (which translates to 'Wordsmiths' in English).

\section{Liberia}

Azango, Mae FORTE Publishers, Monrovia Reads Promotes Reading Culture in Liberia. http://www.frontpageafricaonline.com/index.php/news/4411-forte-publishers-monroviareads-promote-reading-culture-in-liberia [24/06/17]

Reports about a revival of indigenous publishing in Liberia, and a flourishing literary climate in the country, encouraged through initiatives such as Monrovia READS, sponsored by Forte Publishing, http://fortepublishing.wixsite.com/fppp and https://www.facebook.com/fortepublication/, which describes itself as "an indie press dedicated to the identification, production and promotion of African creative literary talents." Most of its writers and poets are first time-authors and emerging voices. Forte offers a full range of publishing services from manuscript development, copy editing, formatting, through to finished copies of the books, as well as sales and marketing.

\section{Nigeria}

Ajeluorou, Anote Book Industry Reels in Debt as Publishers, Booksellers Bicker. https:/guardian.ng/art/book-industry-reels-in-debt-as-publishers-booksellers-bicker/ (Posted 02 April 2017) [05/04/17]

Another version also at https://publishingperspectives.com/2017/04/nigeria-reportedpublishing-crisis/ [10/04/17]

Booksellers' persistent failure to pay publishers for books supplied is threatening to cripple the book business in Nigeria, the author says. Publishers accuse them of failing to remit amounts due even though they have actually sold books supplied to them. Booksellers and distributors, in turn, cite poor sales figures, difficult trading conditions, and the rising cost of running their business as the reasons for their poor credit record. Meanwhile authors continue to put pressure on publishers to pay royalties in a timely fashion even if publishers have failed to receive payment, and with some of them facing severe cash flow problems as a result. Some publishers have reportedly written off huge amounts of bad debts, and publishers say that, in practice, they can only pay royalties based on the money they have received, and not for what they supplied. The result, the author says, has led not only to a climate of mistrust among the different players in the book industry, but also between publishers and their authors. Some publishers are now increasingly turning to alternative models for distribution and retail sales.

Alter, Alexandra A Wave of New Fiction From Nigeria, as Young Writers Experiment With New Genres.

https://www.nytimes.com/2017/11/23/books/fiction-nigeria-writers.html (Posted 23

November 2011) [26/11/17]

A new wave of thematically and stylistically diverse fiction is emerging from Nigeria, as writers there experiment with different genres and explore controversial subjects. Nigerian 
publisher Cassava Republic https://www.cassavarepublic.biz/ can be said to be in the forefront of this literary renaissance, and now the company has global ambitions. Early in 2017 Cassava Republic began releasing its books in the United States, following its expansion into Britain last year. Rather than selling publication rights to American publishing houses, as most foreign publishers do, Cassava Republic prints and distributes its titles to American booksellers and others through Consortium, a book distributor based in Minnesota. Eventually, the company plans to release all of its new titles in the US, with first printings that range from 2,000 to 5,000 copies. Cassava Republic has published more than 50 titles, and has now also expanded its list into romance, crime, memoir, fantasy, science fiction and children's books. Cassava plans to publish nine new titles in the United States in 2018.

\section{Bookshybooks 56 Years of Nigerian Literature: Mabel Segun.}

http://www.bookshybooks.com/2016/10/56-years-of-nigerian-literature-mabel.html

(Posted 26 October 2016) [18/03/17]

A short profile of the Nigerian writer Mabel Segun, who has written prolifically for both adults and children. This post focuses on her range of children's books. A champion for children's literature in Nigeria, Segun was also the founder the Children's literature Association of Nigeria in 1978, and she was instrumental in setting up the Children's Documentation and Research Centre Ibadan in 1990.

Egbedi, Hadassah Okadabooks - The Innovative Platform Revolutionising Book Publishing in Nigeria. http://venturesafrica.com/okadabooks-the-innovative-platformrevolutionising-book-publishing-in-nigeria/ (Posted 20 September 2017) [04/10/17]

Founded by Okechukwu Ofili, Okadabooks http://www.okadabooks.com/ is a publishing/reading platform or app that "seeks to harness the power of the mobile phone to make it easier and cheaper for Nigerians to read", and to give "up and coming authors published or unpublished an avenue to get their works distributed and monetized as early as possible." In this interview Ofili talks about his motivation for starting the company, how it operates, the diverse range of e-books that can be found on its platform, the benefits it offers to authors and the income they are likely to receive if the books are successful, how they protect their digital products from the threat of piracy, and their plans for future expansion.

Graham-Douglas, Ibiso Fiction Book Imports and the Indigenous Publisher in Nigeria.

London: London College of Communication/University of the Arts, 2006. MA thesis (Publishing). 75 pp.

https://www.academia.edu/14531572/Fiction_Book_Imports_and_the_Indigenous_Publish er_in_Nigeria [05/10/17]

Ed. note: This interesting MA thesis, submitted in 2006, has not previously been recorded in the PBERSSA database, but has recently become available online at Academia.edu, and is now included with the present annual literature review.

An MA thesis that examines the state of fiction publishing and bookselling in Nigeria (as at 2006). Its main objective was to establish the patterns of consumption of fiction literature by Nigerians, and at the same time investigate whether book imports of this genre have had an adverse effect on local production by indigenous publishers. The methodology adopted was a combination of both primary and secondary methods of research, using quantitative and qualitative approaches. The lack of information about fiction publishing in Nigeria led to the 
need to conduct primary research using questionnaires and interviews with publishers and booksellers, in order to ascertain industry consensus on publishing and selling of both locally published fiction and foreign imports. The research findings did not support the initial perception that book imports may have impaired the publishing of the genre by indigenous publishers. The findings of the investigation, as well as the literature review, also demonstrated that the publishing industry in Nigeria has been plagued with a number of economic, political and socio-cultural problems, which have hindered its progress generally, and in this case had diminished the publishing of fiction.

However, "fiction book imports in Nigeria have neither impaired nor fostered the publishing of the genre. The lethargic state of fiction publishing is as a result of independent factors that have generally plagued the industry." The main problem with fiction publishing in Nigeria, the author asserts, "is the chasm that exists between two distinct camps within the industry. The first camp consists of publishers and the industries that support them, e.g. printers. The second camp is the booksellers and consumers. The former do not appear to be in tune with the tastes, interests and expectations of their consumers; that is why they have been unable to adequately captivate them. Publishers do not seem to know who their readers/potential readers are. They don't know where they are and how to reach them." Additionally, the author argues, "a successful publishing industry cannot thrive in an unstable and turbulent economic or political environment. ... the emerging trend of fiction publishing in Nigeria hinges on the stable environment as created by the recent return of its government to a democratic system of government, and all the economic reforms that have been implemented since that time." The author concludes with a range of specific recommendations, including consolidation of industry efforts, and the need for research on consumer reading patterns, that would help to boost the publishing of fiction in Nigeria.

Lababidi, Lesley Olatoun Williams: Reviewer of African Literature and Founder of Borders Literature for All Nations.

https://nomad4now.com/2018/01/07/olatoun-williams-reviewer-of-african-literature-andfounder-of-borders-literature-for-all-nations/ (Posted 07 January 2018) [18/01/18]

Olatoun Williams, interviewed here by cultural historian Lesley Lababidi on her lively blog, is a Nigerian literary reviewer actively promoting the reading culture in Nigeria. She reads African books on television, radio and online platforms, as well as providing visibility for African-published books worldwide. Williams is the founder of Borders Literature Online http://www.bordersliteratureonline.net/, which has recently featured a series of interviews with prominent members of the Nigerian book professions, and the site also includes a rich archive of book reviews.

Nawotka, Ed Cassava Republic Brings Africa to America.

https://www.publishersweekly.com/pw/by-topic/international/international-booknews/article/73739-cassava-republic-brings-africa-to-america.html (Posted 30 June 2017)

Nigerian publisher Cassava Republic https://www.cassavarepublic.biz/ has begun distributing books through Consortium http://www.cbsd.com/ in the United States, having earlier launched a UK operation in April of 2016. Asked why she decided to expand to the US, Bakare-Yusuf said that it was partially about "legitimacy" and would play well at home, giving her publishing a house an edge in attracting talent. But, she added, there's something more at stake than mere pragmatism: "Our aim is to show the broader reading audience that 
there is more to African life and literature than what you might read in the news. We know that many Americans will pick up these books out of curiosity at first. But they will find stories that they themselves can relate to and characters they can identify with."

Prospero [pseud.] From Abuja to the Arctic. Norway and Nigeria's Unlikely Bibliophilic Collaboration. http://www.economist.com/blogs/prospero/2017/06/abuja-arctic [28/06/17] Another story also at https://publishingperspectives.com/2017/06/norway-nigeria-librarydigitization/ [28/06/17]

The National Libraries of Nigeria and Norway are to sign a letter of intent concerning the digitization of books in Nigerian languages by the National Library of Norway. "Our aim is to give access to digitized books in indigenous Nigerian languages to Nigerians living in Norway through our multilingual library. We also hope that this project becomes a model for our cooperation with other countries, and the success of more African languages" JensPetter Kjemprud, Norway's ambassador to Nigeria is quoted as saying. The agreement will cover literature written in the Nigerian languages of Hausa, Yoruba, and Igbo (although the first two can be described as cross-border languages, also spoken in some other countries of the West African region). The costs will be shared, with the library in Nigeria responsible for collecting and making available copies of the material to be digitized, while the Norwegians will be responsible for undertaking the digitisation. Questions relating to formats and access (and rights issues?) will presumably be answered in the months ahead, and this is certainly a most welcome development and might well serve as a pilot for similar collaborative ventures with African national libraries elsewhere with significant holdings in African language materials.

Note: Surprisingly, the website of the National Library of Nigeria http://www.nln.gov.ng/ carries no news of this project and searches at its online National Union Catalogue at http://www.nln.gov.ng/onuc all come up with a message saying "...document will be attached soon", while search facilities in its Nigeriana Repository online pages at http://www.nln.gov.ng/repository don't seem to work either (when accessed in January 2018); and so there is presently no online catalogue information of any kind about the richness of its collections in Nigerian languages.

Ryssdal, Kai Publisher Cassava Republic is Changing the Way we Read about Nigeria. https://www.marketplace.org/2017/05/08/business/publisher-cassava-republic-changingway-we-read-about-Nigeria (Posted 08 May 2017) [24/06/17]

An interview with Bibi Bakare-Yusuf, co-founder of Nigerian publisher Cassava Republic https://www.cassavarepublic.biz/ in 2006, and who opened a branch in the UK ten years later in 2016. In establishing the company, she says "one of the things I was very concerned about is the representation of African books, where there's a certain imagery of Africa, but it also doesn't reflect the complex, gorgeous realities of the continent as it is today rather than an imaginary world. So I wanted a branding that was very confident, that still incorporate the colours of Africa on one level, but also branding that suggests a certain cosmopolitanism."

Segun-Amao, Bimbola Ofili Okechukwu and the OkadaBooks Story: CP-Africa Interview. https://www.cp-africa.com/2017/08/11/ofili-okechukwu-okadabooks/ (Posted 11 August 2017) [01/09/17]

Founded by Nigerian entrepreneur Okechukwu Ofili in 2013, Okadabooks https://www.okadabooks.com/ is an e-distribution start-up that has developed a popular publishing/reading app for Android mobiles or tablets and other platforms. It takes its name 
from the Okada motorcycle taxis, commonly used in Nigeria and in other parts of West Africa used to overcome traffic congestion. Okadabooks says it "seeks to bypass the traffic in the Nigerian book publishing industry by making it easy to publish books, making it cheap to buy books, but more importantly making it fun to read books on mobile devices....We created the platform primarily to give up and coming authors published or unpublished an avenue to get their works distributed and monetized as early as possible.... It's a fast, simple and fun way to read books without ever leaving your couch!" It thus seeks to harness the power of the mobile phone to make it easier and cheaper for Nigerians to read. Available on several platforms, Okadabooks accepts credit/bank card payments from all over the world. Authors earn a 70\% royalty from each sale, but a cumulative income of at least N10,000 (ca. GBP22.00) has to be accrued before earnings are remitted. Books are available in all parts of the world. At this time more than 120,000 users are registered on the platform.

In this perceptive interview Ofili talks about the Okada story, how it started and was funded, the e-technology they use, the number of books they offer and their authors, their current challenges on various fronts, the business lessons they have learnt so far, and also offers some sound advice for fresh tech entrepreneurs: He says that it is easy to get a bit of media coverage in Nigeria, and "so you may believe your idea is great, not realizing it is not. So don't judge yourself by vanity metrics. Judge by quality and impact metrics, like traction, revenue and growth."

\section{Segun-Amao, Bimbola Books, Digital Publishing, Opon Imo: CPAfrica Interviews Gbenro} Adegbola, MD First Veritas.

https://www.cp-africa.com/2017/08/29/books-digital-publishing-opon-imo-cpafricainterviews-gbenro-adegbola-md-first-veritas/ (Posted 29 August 2017) [01/09/17]

An interesting interview with Nigerian publisher Gbenro Adegbola, CEO of First Veritas Educational Content Delivery Ltd http://1stveritas.com/, a leading player in the digital publishing industry in that country, and who was also actively involved in the Opon Imo (Tablet) project of the Osun State government for senior secondary school students http://osun.gov.ng/education/opon-imo/. Adegbola talks about his background and what led him into digital publishing ventures, developing and delivering educational content, and the hurdles and challenges that had to be overcome in the process. He does not share the common view of poor professionalism in the Nigerian book industry. Instead, he says, "the problem really stems from an extremely low entry barrier to the industry, which means that many companies who do not have the right resources have found their way into industry." While the industry has grown and has achieved almost 100\% local authorship at the lower educational level, and which is a significant achievement, another problem is the lack of institutions offering degree/training programmes for prospective book industry professionals. "Publishing is a fairly tough business anywhere in the world, in the sense that there is no perfect science of determining what book will sell. That is why most Nigerian publishers have taken the line of least resistance and limited themselves to educational publishing, where the numbers [of primary school pupils] are just incredible."

Note: for two other interviews with Gbenro Adegbola see also Gbenro Adegbola: Copyright War Will be Better Served with Public Education http://sunnewsonline.com/gbenro-adegbola-copyright-war-ll-be-better-servedwith-public-education/ (Posted 27 May 2017) [01/09/17]

Williams, Olatoun Interview with Gbenro Adegbola in this section:

http://www.bordersliteratureonline.net/tradedetail/Gbenro_Adegbola [30/10/17], also at

https://www.academia.edu/34941205/Interview_with_Gbenro_Adegbola_First_Veritas. 
Udeze, Sunny, and Anthony Ogbonna Uche, Prospects and Challenges of Publishing in Africa: Insight from a Nigerian Indigenous Publishing. [Lacks date of publication; unpublished?]

https://www.academia.edu/30763459/PROSPECTS_AND_CHALLENGES_OF_PUBLISHI NG_IN_AFRICA_INSIGHT_FROM_A_NIGERIAN_INDIGENOUS_PUBLISHING_FIR $\mathbf{M}[17 / 08 / 17]$

"Explores the prospects and challenges of book publishing in Africa", but primarily focuses on Nigeria. The study, "underpinned by libertarian theory" of mass media, had three objectives: "To find out the contributions that indigenous publishers are making towards the development of the Nigerian economy, to explore the challenges facing the book industry [in Nigeria] as well as the prospects available for book publishing." Somewhat unorthodox, data was gathered by means of a survey questionnaire circulated to the entire workforce of Literamed Publications Nigeria Ltd., [trading as Lantern Books https://www.lanternbooks.com/] a total of 361 members of staff. Each questionnaire asking for response to a number of questions - such as what are the most significant challenges faced by the publishing industries? What are the future prospects and opportunities for the industry? that were thereafter analysed and evaluated. In a summary of their findings the authors state that the publishing industry is "bedevilled by several challenges ranging from the paucity of infrastructure such as electricity, high cost of paper (which is a major raw material in book publishing), lack of credit facilities, and the persisting problem of book piracy. The prospects for the company include the ever expanding population, which in turn creates huge market for the company as more people enrol in schools; the policy of compulsory basic education and government bulk purchases which ensure steady market for their publications."

Williams, Olatoun Interview with Bankole Olayebi.

http://www.bordersliteratureonline.net/tradedetail/Bankole_Olayebi [15/10/17]

Also at https://www.academia.edu/34784471/Interview_with_Bankole_Olayebi_Bookcraft

An insightful interview with Nigerian publisher Bankole Olayebi of Bookcraft Ltd http://bookcraftafrica.com/index.php. Established over twenty years ago, the company has published a large number of high quality titles in a diverse range of subjects, including art, biography, history, literature, politics, current affairs, as well as general trade books and large format coffee table titles. Olayebi talks about the challenges of the book industry in Nigeria, challenges which have become ever more acute in recent years. One of them is the dearth of qualified and well-trained, publishing professionals (designers, editors, proof readers, book packagers, and others) "who understand how the book business should work. It seems to me that over the years regrettably, not enough time and effort has been invested in the training of publishing professionals. The result is that today, it has become very difficult to find the right people to fill various roles; and it's not very easy to find people to train for these roles." Bookcraft is now actively involved in e-book publishing, but Olayebi says "I do not see e-books completely supplanting print book, anytime in the immediate future. I believe that print, or physical books will always be with us. Even in the US and in Europe, the advent of the e-book has not resulted in the death of the print book, as some people were so quick to predict, a few years ago! To paraphrase Mark Twain, 'reports of the death of the print book have been grossly exaggerated'." 
Publishing in Nigeria is in crisis, and efforts to strengthen the Nigerian book industry is going to require the involvement or contribution of the entire gamut of stakeholders government, the private sector, academic institutions NGOs, philanthropists even - in order to put the industry back on its feet. It seems to me, Olayebi says, "that we have got to start from scratch and build the industry back. There's no question that the book industry as a whole has suffered a number of setbacks in the last couple of decades; some of this selfinflicted, in my opinion. And this is because not enough has been put back, especially by those in the industry, in terms of investment in human, financial resources, infrastructure, etc., to properly grow the industry."

\section{Williams, Olatoun Interview with Gbenro Adegbola.}

http://www.bordersliteratureonline.net/tradedetail/Gbenro_Adegbola [30/10/17]

Also at

\section{https://www.academia.edu/34941205/Interview_with_Gbenro_Adegbola_First_Veritas}

A further interesting interview in the Borders Literature Online series of interviews with members of the African book professions. Here Olatoun Williams is in conversation with Nigerian publisher and digital entrepreneur Gbenro Adegbola of First Veritas http://1stveritas.com/, in which he talks about his background, how he got into publishing, the digital vs. print debate, developing digital content, the need to invest in publishing training and education, the major challenges facing the Nigerian book industries and the main threats to the industry, with the menace of piracy high up on the list. Another major hurdle, he says, is access to funding and credit: "I find that the financial industry is blissfully ignorant of what we do. They don't understand it. They confuse it with printing and that has affected access to credit. In fairness to them, the role of the publisher is not so obvious. The understanding of what publishing constitutes how publishers make money - you find that a lot of people don't understand it."

One major challenge for the book industries, Adegbola says, is the current dearth of training opportunities and professional development courses: “The industry can't go into universities and tell them to set up publishing courses. What is needed is for the self-help courses organised by the industry to be strengthened and expanded initially. And individual companies should invest more in training, possibly overseas training as well. The traditional excuse is that if you train someone, there is no guarantee they will stay. My position is that the experience will not leave the industry. It remains in it even if they don't stay with your company. So people have to take an industry-wide attitude."

\section{South Africa}

Flynn, Sean Why Fears about 'Fair use' Copyright Law are Unfounded. https://www.businesslive.co.za/bd/opinion/2017-08-04-fears-of-fair-use-law-being-usedto-rip-off-rights-holders-are-unfounded/ (Posted 04 August 2017) [18/09/17]

The South African parliament has been hearing about 'fair use' while it considers the Copyright Amendment Bill, part of which includes the introduction of a 'fair use' right. It has been suggested that as a result of the 'fair use' clause academic writers of prescribed university books will be put in the position where a university might buy just one copy of a book and then makes free copies for its 2,000 students, without compensating the author at all. However, these claims, the author says, are completely unfounded, and "the term 'fair 
use' comes from a provision of the copyright act in the US that was passed in the 1970s, around the same time that South Africa created an exception for 'fair dealing'. Both 'fair use' and 'fair dealing' are general exceptions to copyright. They state that a person can use (or deal with) a copyrighted work as long as that use is fair to the rights holder. The South African fair dealing clause only applies to a narrow list of purposes including research or private study, personal or private use, criticism or review, and reporting current events."

Mbete, Buhle Thabiso on her Unapologetically Black Publishing Company. http://www.destinyconnect.com/2017/02/03/thabiso-unapologetically-black-publishingcompany/ (Posted 03 February 2017) [05/05/17]

A short profile of Thabiso Mahlape, Founder of BlackBird Books http://www.jacana.co.za/blackbird-books, co-founded with her previous employer South African publisher Jacana Media and operating as an imprint of that company. Blackbird Books was launched as a platform and a publishing home to both new voices and the existing generation of black writers and narratives. Mahlape says "Blackbird Books publishes purely black writers and black narratives. Two of the books I've published had been rejected because they were unapologetically black. Blackbird has given a platform to voices that would otherwise have not been heard."

Mda, Zakes The State of a Reading/Writing Nation. Address at the Opening of the South African Book Fair, 8 September 2017. http://city-press.news24.com/Voices/we-must-create-a-culture-where-reading-in-alllanguages-is-respected-20170919 [02/11/17]

https://www.scribd.com/document/359298371/South-African-Book-Fair-Keynote-

Address\#from_embed (Complete text of address) [02/11/17]

In this eloquent address Zakes Mda - the award-winning South African novelist, playwright, and poet - describes the state of the book and the culture of reading in South Africa today, and also offers some astute observations about the new digital environment, social media, pulp fiction, and informal reading circles and book clubs. Reading in all languages must be respected and, he says, "it saddens me that today literature in indigenous African languages is so marginalized that we can only conceive of a culture of reading in English. This is not because books in indigenous languages do not exist. Every year new books are published in most of the languages of South Africa, in addition to the classics in languages such as isiXhosa, Sesotho and isiZulu that have had a literary tradition dating from the 1800s. The problem lies with book distribution rather than the book publishing sector. You may go to any of our major bookstores chains today, say Exclusive Books or CNA, and ask for the latest Sesotho novel by Nhlanhla Maake, a Setswana novel by SabataMpho Mokae or an isiXhosa novel by Ncedile Saule, and the likelihood is that you will not find it in stock. It is a Catch 22 situation because the bookstores will tell you they don't stock such novels because no one buys them, but the readers will tell you they don't buy them because they are not in stock. This is a cumulative result of the marginalization of indigenous languages in South Africa today in all spheres of life."

He is critical of the sharp decline in editorial standards in publishing in South Africa. For example celebrity books bring a lot of money to publishers and some want to churn them out of the conveyer belt without proper editing, disrespecting new and young readers because they think they have no discernment. "Poor editing is the bane of South African 
books generally, even so-called quality fiction and non-fiction by reputed publishers ... Publishers in South Africa are letting reader and writer down, and disrespecting them. Such shoddiness will be the death of the book."

Zakes Mda ends his address by emphasizing that cultures reproduce themselves: "A reading culture once cultivated produces more readers and more readers produce more writers, who then in turn produce more readers. It all begins with a seed."

Mila [Anon.] Six Local Authors and Publishers on Decolonising Editing in South Africa: A Panel Discussion.

http://jacana.bookslive.co.za/blog/2017/08/03/six-local-authors-and-publishers-ondecolonising-editing-in-south-africa-a-panel-discussion/ (Posted 03/08/17) [28/01/18]

Reports about a panel discussion on "decolonising South African editing" hosted by Jacana Media at the University of the Witwatersrand. The panellists were a number of South African writers, in conversation with the author of Endings $\mathcal{E}$ Beginnings Redi Tlhabi, who opened the floor by posing the question what decolonisation means and how it manifests in African literature.

Nell, Olinka "Pretty Gloomy with no Resilience in the Market. Trade Sector Report." Bookmarks Issue 90 (Sep.-Nov. 2017): 14-15.

https://www.sabooksellers.com/wp-content/assets/BookmarkIssue90.pdf [20/10/17]

A report about the current state of the book trade in South Africa, which is facing challenging times. Copyright is a huge issue for academic booksellers, while centralised procurement of school textbooks cuts the educational booksellers out of the equation. The general book trade struggled in the first half of 2017, as consumer confidence slumped and food prices continued to rise. The only reprieve came from a fairly stable currency, which saw book prices flatten out or even decline. Key challenges in the sector at present include the escalating theft of books, now on a cross-border scale, and a critical shortage of skills. On a positive note, Exclusive Books, the country's leading book retailer, reported a marked shift in the market, with their Pan-African writers list showing more than $60 \%$ growth.

Rose-Innes, Henrietta “The Tremors Through South African Literature." Times Literary Supplement July 13, 2017

https://www.the-tls.co.uk/articles/public/tremors-south-african-literature/ [18/08/17]

A thoughtful article by South African novelist and short-story writer Henrietta Rose-Innes. It takes the reader through her experience as a writer in the post-apartheid era since the late 1990s, "when South African writing still felt isolated from the rest of the continent and the world", but "a handful of venerable literary magazines with tiny circulations existed, and a small number of publishers valiantly focused on local work." That included Kwela Books, an imprint tasked with publishing new and diverse voices in the post-apartheid era. Thereafter, around about the mid-2000s, "something else started to happen: genre fiction erupted. Suddenly it was acceptable for local writers to take to crime." Along with this shift, the author says, came greater visibility for local literary fiction. Book clubs that previously would only read international prize-winners started paying attention to home-grown authors. Prizes, festivals and creative writing courses multiplied. These creative writing programmes in particular succeeded in promoting a slew of talented new writers, and new publishing activities. 
Nonetheless, "times remain tough in publishing, in South Africa as in the world. Sales of literary fiction are sparse and growing sparser." Right now the major tremors running through the South African literary world have to do with race: "Race is, as always in South Africa, the issue, and through all the country's changes, the publishing establishment has remained stubbornly white-dominated. In conjunction with the past two years' fierce student activism for the 'decolonization' of universities, a movement to 'decolonize' literature has taken root." A new festival, the Abantu Books Festival https://www.abantubookfestival.co.za/, specifically for black writers and readers, was founded last year by the author Thando Mgqolozana, and took place for the second time in December 2017, in Soweto. Blackbird Books http://www.jacana.co.za/blackbird-books, likewise, is a new publishing imprint founded in 2015 for exclusively black writing. Most significantly though, there is a cohort of younger writers who have taken their places on the literary stage: "These transformations are turbulent, hopeful, at times confrontational, at times euphoric - and long overdue. South African writers may take a decade or two to process our radical shifts, but we get there in the end."

\section{Smit, Sarah Finding Affiliations: Reading Communities, Literary Institutions \& Small Magazines. \\ https://africainwords.com/2017/10/21/finding-affiliations-reading-communities-literary- institutions-small-magazines/ (Posted 21 October 2017) [12/11/17]}

Reports about a get together of writers and literary producers in Cape Town in April 2017 for a workshop exploring 'Small Magazines, Black Archives and Personal Histories'. This article engages with three separate conversations that formed part of the workshop, "each of which loosely responded to the need to attend to 'unofficial' sources of affiliation on the continent and put into conversation experts on and contributors to alternative institutions of contemporary literary and cultural production." Another part of the agenda was to address the issue of literary festivals, book prizes, and the politics of cultural production.

Smith, Carin New Copyright Bill May Negatively Impact Publishers - PASA. https://www.fin24.com/Economy/new-copyright-bill-may-negatively-impact-publisherspasa-20170802-2 (Posted 02 August 2017) [15/09/17]

The publishing industry in South Africa will experience significant negative consequences should the proposed exceptions of the 2017 Copyright Amendment Bill be introduced, according to the Publishers Association of South Africa (PASA) http://www.publishsa.co.za/. The association presented arguments in this regard to Parliament, based on an economic impact assessment by PwC on the detrimental effect certain provisions of the bill could have on the publishing industry, and as set out in PASA's July 2017 submission document http://www.publishsa.co.za/file/1501661689hnfpwcreportonthecopyrightbill2017.pdf.* An overwhelming majority of $89 \%$ of the publishers surveyed in the assessment reportedly believe the promulgation of the bill, as currently worded, will impact negatively on their operations. In many cases the response to these negative impacts would require significant restructuring, retrenchments and, in some cases even business closure, PASA state. The report found that the proposed amendments would result in declining revenue from sales of educational publications, a sharp reduction in licensing income via collective management organizations, as well as an erosion of the incentive for the creation of educational works. 
PwC was engaged by PASA to conduct an objective and independent assessment of the impact of the provisions relating to 'fair use' and exceptions for educational and academic activities, and PASA is especially concerned about the potential negative impact the bill could have on educational publishing, if it is passed in its current form. According to PASA Chair Brian Wafawarowa, educational publishing forms about $60 \%$ of all publishing in South Africa: "As the licensing model changes and textbooks are starting to be phased out and replaced by digital tools, one should not confuse the issue of copyright with that of funding," he stated at a recent media briefing. "The burden of affordability cannot be shifted onto the copyright holders. Copyright is also an incentive to create and publish. There is a lot of unauthorised usage, but we are reluctant to prosecute universities and schools. Some people even 'hijack' businesses and sell (copyrighted) material to schools."

"Notes: see also (i) the earlier 2015 submission document http://www.publishsa.co.za/file/1494421942pjppasasubmissiontodti-copyrightamendmentbill2015.pdf, and (ii) South Africa Copyright Amendment Bill 2017 below.

\section{South Africa Copyright Amendment Bill 2017}

http://libguides.wits.ac.za/ld.php?content_id=32174808 [11/11/17]

South Africa has released a revised version of the 2017 Copyright Amendment Bill, introduced into the National Assembly on 16 May 2017 in terms of Section 75 of the Constitution. The Copyright Amendment Bill, which was first published for comment in July 2015, has been both commended and criticised by stakeholders and experts in the field. Below are links to a range of submissions and comments on the Bill.

http://libguides.wits.ac.za/ldd.php?content_id=33607968

http://infojustice.org/archives/38242

http://theconversation.com/south-africa-takes-steps-to-adjust-copyright-law-to-thedigital-age-81490

https://www.businesslive.co.za/bd/opinion/2017-08-04-fears-of-fair-use-law-being-usedto-rip-off-rights-holders-are-unfounded/

http://www.litnet.co.za/comments-by-pen-afrikaans-on-the-copyright-amendment-billno-13-of-2017/

Taylor, Darren Used Book Sales Boom in South Africa as Economic Recession Bites. https://www.voanews.com/a/used-books-sales-boom-in-south-africa/3965919.html (Posted 31 July 2017) [30/09/17]

South Africa entered an economic recession in June 2017, and the country's unemployment rate is fast approaching 30 percent, according to the government statistics agency. But for the sellers of used books, business has never been better according to veteran South African second-hand bookseller Eric Nofal of Books Galore http://www.booksgalore.co.za/. Five years ago Nofal's sales dropped dramatically when book lovers began embracing electronic reading devices like Kindles and he had to close six stores. But now, Nofal says, the "Kindle craze" may be over and many South Africans want to turn "real pages." Part of the reason, he says, is that new titles now cost too much in the country. Meantime another second-hand and rare books dealer, Doron Locketz of Bookdealers https://www.bookdealers.co.za/, reports that despite the poor economy some South Africans spend "big money" on rare second hand titles. However, he also says that the collectible book market is still very small, and he mostly sells used books to a general audience. 
Wanner, Zukiswa Writing's on the Wall for Parochial SA Publishers.

https://mg.co.za/article/2017-09-27-00-writings-on-the-wall-for-parochial-sa-publishers

(Posted 27 September 2017) [06/11/17]

As a writer published in South Africa, Zukiswa Wanner says, "I work in an insane industry.

... Twenty-seven years after Nelson Mandela walked out of prison, the South African publishing industry's articles of faith still remain that middle-class white women are the biggest readers and buyers of books, and that nonfiction sells more than fiction." She argues that "part of the disconnect between writers and white publishers has been very much ingrained in this fallacious belief that a certain demographic of people does not read. And now that same demographic is not only reading but buying books. Publishers continue to fail their writers in not recognising this." It is a mistake, she says, for the publishing industry to say that only a certain demographic is not reading. "Not buying books is not the same as not reading." Wanner also claims that the publishing industry has failed to interact with black bookstore owners. "The insanity will continue. Traditional mainstream publishers may not die by refusing to adapt, but they shall be comatose for a very long time" she proclaims.

Wilkinson, Kate Do only 14\% of South Africans Read Books?

https://africacheck.org/reports/14-south-africans-read-books/ (Posted 08 September 2017) [07/11/17]

South Africa's basic education minister, Angie Motshekga, often berates the lack of a book reading culture among South Africans. "Do you know that reading statistics show that only $14 \%$ of South Africans are readers of books?" the minister said in a video* promoting a reading event held in 2016. But is the situation as dire as she suggests? Citing stats from a study of grade 4 pupils, reading studies published by the South African Book Development Council, time use surveys (which defined reading to include the reading of books, magazines and newspapers, both in print and online), and other research on book reading in South Africa, the author suggests that this does not support the basic education minister's claim: "When reading of books is isolated from other types of reading, $25 \%$ of respondents reported reading books" in a 2016 study, although "just over 16 million adults in South Africa (58\%) reported living in a household with no books. The remaining $42 \%$ of people lived in households with more than one book."

*Note: see https://www.youtube.com/watch?v=F3qeEX_bfX4\&feature=youtu.be\&t=16

\section{Tanzania}

Saiwaad, Abdullah Interventions in Book Provision: Suffocating Education and the Local Book Industry the Case of Tanzania.

http://www.ucwia.or.ug/book\%20industry\%20suffocation.pdf (Full text, pdf) [19/12/17] http://www.ucwia.or.ug/IBBY\%20Uganda\%20Saiwaad\%20Presentation.pdf (PowerPoint presentation)

A paper presented at the 4th IBBY Africa Region conference, Rethinking Contemporary Literature for Children and Young People in Africa, Kampala, 22-24 August 2017, which presents a gloomy picture of publishing and the book trade in Tanzania.

In Tanzania, the author says, "it is evident that the book sector has not been developing at a pace commensurate with the growth of the population and the other economic sectors in the 
country." After a period of relative growth and prosperity for the private sector from 1993 to 2013, publishing and the book trade is now once again in sharp decline. The reasons for this are many and cut across socio-political and economic factors. But above all it is government action through detrimental policy measures - including language, education and textbook policies - that have been instrumental in retarding the growth of the book sector. In earlier years government action, through positive and enabling policy measures, had been the key to a revival of the sector. These recurring changes in government policies have once more contributed to the curtailing of the book trade in Tanzania. Educational and textbook policies that have previously failed are once again introduced as 'new' policies a few years later, only to fail yet again.

Saiwaad states that there has been government interference at almost every level of the 'book chain' and textbook provision, for example in the area of authorship of textbooks: "Many politicians believe the best authors of textbooks are teachers. Indeed many of them are. But not all good teachers are good authors! Interference in the book chain arises of the belief that all teachers can write. Therefore without any tests whatsoever, a group of teachers is selected, given the syllabus, pens and paper and requested to write a book for say class three. A certain specific time is given and usually an unrealistic time frame. The end product, which to them is a manuscript for a textbook, would be thrown out of the window without hesitation by any editor worth the name. Interference in authorship is also supported by some development partners. They support a project which would never have been supported by authors in their own countries."

Direct intervention in textbook provision policy has been detrimental to the development of a healthy and dynamic indigenous book industry. "Politicians and government bureaucrats fail to understand that publishing is a process. They believe that they can separate the work of the editor, designer and illustrator and still produce good quality books. Experience is irrelevant. In 2013, on the excuse that teachers are confused due the abundance of textbooks, the Ministry of Education of Tanzania, ordered that all books will be authored and published by the Tanzania Institute of Education (TIE)."

Meantime the retail book trade has also been adversely affected; there have been serious deficiencies in the distribution of textbook via TIE, and the number of active booksellers, and bookshops generally, has dropped sharply. Adequate funds to purchase new books for refreshing library collections which are part of the Tanzania Library Services Board are rarely made available, and the public library network is thus heavily dependent on book donations, most of them from overseas. A national book policy is still not in place, although the country's Book Development Council (BAMVITA) managed to draft a national book policy. However, "it is still gathering dust in the Ministry of Education offices in Dar es Salaam. The Council has remained just in name. There is a serious need for book industry stakeholders to wake up and put their industry in order." 


\section{Uganda}

Musinguzi, Bamuturaki Uganda: Writers Taking On Publishing. http://allafrica.com/stories/201705290389.html (Posted 25 May 2017) [26/06/17]

The 2017 Uganda International Writers Conference, organized by the African Writers Trust in Kampala, had 'Contemporary Publishing Trends in Africa' as it focal theme. Bibi BakareYusuf, the co-founder of Cassava Republic Press in Nigeria https://www.cassavarepublic.biz/, presented the keynote address: The Current State of African Publishing: Dare we Hope? This short report includes some extracts from her address, and statements by other speakers.

\section{Zambia}

Chilala, Cheela Himutwe K. "Anatomy of the Challenges Facing Zambian Writers and Publishers of Literary Works." Journal of Southern African Studies 40, no. 3 (2014): 593-606. http://www.tandfonline.com/doi/abs/10.1080/03057070.2014.909659 [10/02/17]

The author argues that the publication of literary works in Zambia has been held captive by the challenges facing the book industry, in particular the country's economic crisis. These economic challenges have led to high costs in publishing, and inevitably the cost of purchasing books has also been high. Zambian publishers are largely depended on government procurement for their book sales, primarily purchasing textbooks. Some publishers have depended on sales of textbooks in order to generate funds to publish literary works, but this overdependence on government procurement has left publishers financially vulnerable. The diminished publishing opportunities for writers of literary works have driven some writers into self-publishing as an alternative. However, this option has not answered the problem, in part because it relates more to quantity rather than quality of publications. Some interventions by writers' and book trade associations, the Curriculum Development Centre, and a number of writing awards, have provided a measure of stimulation. A change in government policies, however, could go a long way towards stimulating the growth of the industry and exposing unknown writing talent.

\section{Zimbabwe}

Kubuitsile, Lauri Thoughts from Botswana. amaBooks, A Zimbabwean Publisher. https://thoughtsfrombotswana.blogspot.co.uk/2017/09/amabooks-zimbabweanpublisher.html (Posted 08 September 2017) [04/10/17]

Another version also in https://publishingperspectives.com/2017/09/zimbabwe-amabooksfiction-bulawayo/

A conversation with Jane Morris, one of the founders of amaBooks http://www.amabooksbyo.com/, a small independent imprint located in Zimbabwe's second city of Bulawayo, publishing a wide range of contemporary Zimbabwean writing. Jane Morris answers questions about current book trade conditions in the country, the assistance amaBooks offers to new writers keen to break into print, the prospects of an intraAfrican book trade, the decline of Zimbabwe's literary community, what she see as the biggest challenges to publishers on the continent, and what have been the most significant successes for amaBooks. But how does one measure success? "For me, one success, despite all the stressful times, has been the joy that amaBooks has brought into our lives, being 
greeted in the streets of Bulawayo with 'Hey amaBooks'. Getting good reviews from readers and critics is one of the things we value most. We love what we do and it is heartening when others enjoy the books we have brought out."

\section{Reading Zimbabwe}

https://www.kickstarter.com/projects/2099710239/reading-zimbabwe [18/12/17]

Describes the activities of Reading Zimbabwe http://readingzimbabwe.com/ and the creation of a digital archive and repository of books written and published about Zimbabwe. This kickstarter project "was born out of a curiosity for a deeper understanding of the nature and extent of knowledge production, dissemination and use around the subject of 'Zimbabwe.'" Reading Zimbabwe, founded in 2016 by Tinashe Mushakavanhu and Nontsikelelo Mutiti, is largely a virtual project, an interactive digital library, and its "ultimate aim is to build a physical People's Library to complement poorly resourced libraries in Zimbabwe." The repository currently (December 2017) contains references to 1,538 books, written by 957 authors, and published in 114 cities by 397 publishers. The database can be searched by authors, by broad subject areas, as well as other search options such as 'Decade', 'Continent', or 'Motif'. While still in a development stage, this is already an immensely rich database and its creation amounts to an astonishing labour of love. See also a short video presentation about the projecat https://vimeo.com/239058388.

Note: not to be confused with Zimbabwe Reads https://zimbabwereads.org/, an organization that supports the reading culture in the country by distributing and donating reading materials, promoting reading activities; and works with local publishers, authors, and cultural associations to support children's books and publications in Zimbabwe's indigenous languages.

\section{STUDIES BY TOPIC}

\section{Authors and publishers/Publishing of African writers and African literature (in Africa and elsewhere)}

Davis, Caroline "Playing the Game? The Publication of Oswald Mtshali," in Bourdieu and Postcolonial Studies, edited by Raphael Dalleo. Liverpool: Liverpool University Press (Postcolonialism across the Disciplines, 19), 2016, 137-158.

Oswald Mbuyiseni Mtshali (b. 1940) is a South African poet who has written in both his mother tongue of isiZulu as well as in English, and is best known for the poetry collections Sounds of a Cowhide Drum and Fireflames. The first anthology, published in 1971 and containing a foreword by Nadine Gordimer, enjoyed remarkable success, albeit also subject of several controversies, notably by critics overseas. Published by Johannesburg-based Renoster Books, an imprint created and led by Lionel Abrahams, over 16,000 copies were sold in the first year, as the book ran through six impressions. A US edition (Third Press, New York) appeared in the following year, as did a British one, published by Oxford University Press. The book was further honoured by the award of the 1974 Oliver Schreiner Poetry Prize. Mtshali's second volume, Fireflames, was published in 1980 by Shuter and Shooter and was promptly banned by the South African government of the time for its antiapartheid stance. Sounds of a Cowhide Drum was later reissued by Ad Donker in 1982 and, more recently, a new edition was published by Jacana Media in South Africa in 2012. http://www.jacana.co.za/book-categories/fiction-poetry-a-writing/sounds-of-a-cowhide- 
drum-imisindo-yesighubu-sesikhumba-senkomo-detail. The new edition carries a simultaneous isiZulu translation of the poems, and a new foreword by Nadine Gordimer.

Based mainly on oral histories and new archival research, this is a fascinating investigation how Mtshali's various publishers shaped his literary identity and positioned him in the international literary marketplace. The study also reveals disputes between OUP and Joseph Okpaku's Third Press in New York (also maintaining offices in Lagos) about the question of territorial rights, disagreements over the editing of the poetry, and conflict over the book's design and format, as well as production standards. The Third Press went ahead with the production of Sounds of a Cowhide Drum in its own preferred format and design, although Mtshali has claimed (in a 2014 personal interview cited in the article) that he never signed a contract with Third Press nor received any monies or royalties from them. The OUP edition was published in 1972 in its Three Crown Series, which was situated within OUP's African educational programme. Davis says "although Mtshali's book was at the center of various conflicts between the publishers, the author was far removed from these matters, and was entirely unaware of the games relating to neocolonial trade agreements, postcolonial politics and cold-war publishing in Africa that were evidently played out by his publishers." Mtshali claims to have received little income from his OUP royalties, and his international publishing history, the author says, throws into question the assumption that a highly prestigious or highly 'consecrated' international publisher automatically accords acclaim to the postcolonial writer. Mtshali was caught up in “OUP's fraught and contradictory publishing policies in Africa. The decision to publish his poetry in the mass-market Three Crowns series, with its low production standards, low unit prices, and its main market to African schools, meant that Mtshali accumulated little in the way of either symbolic capital or economic capital from this publication."

The most recent edition of Sounds published by Jacana Media in 2012 was intended to relaunch Mtshali's work for a new generation of South Africans, and at the same time was targeting the educational markets. However, Jacana's "valiant attempt" to relaunch Mtshali as a classic has reportedly had limited success to date, despite its availability in an affordable paperback as well as in a Kindle edition. Sales have been disappointing and the publishers have thus far failed to get the book adopted by government educational establishments. This, Davis concludes, "was ultimately a conservative and nostalgic publishing venture, which relied on the same publicity devices as his original publication forty years earlier, and appears predominantly to have reached the same audience." Each of Mtshali's publishers, in various geographical and historical contexts, "played different and sometimes conflicting games, each operating by different rules and for different 'stakes', relating to race and culture in South Africa during apartheid; neo-colonialism in British publishing; cold war cultural politics in America; and most recently, to cultural and linguistic tensions in postapartheid South Africa."

Note: An interview with Mtshali, recorded in 2014, can be found at http:/htmlgiant.com/author-spotlight/sounds-of-a-cowhide-drum-an-interview-with-mbuyiseni-oswaldmtshali/ 
Jackson, Jeanne-Marie New African Literature is Disrupting what Western Presses Prize. https://theconversation.com/new-african-literature-is-disrupting-what-western-pressesprize-85206 (Posted 09 October 2017) [10/11/17]

Another version also at https://qz.com/1103001/writers-like-chimamanda-adichie-and-tejucole-are-not-all-there-is-to-african-literature/

Nowadays African literature is the object of immense international interest across both academic and popular registers: "Far from the field's earlier, post-colonial association with marginality, a handful of star 'Afropolitan' names are at the forefront of global trade publishing", the author says, but such commercial prominence has attracted considerable push-back from Western and Africa-based critics alike. "Far from advancing narratives with deep roots in local African realities, such critics fear, many of Africa's most 'successful' writers hawk a superficial, overly diasporic, or even Western-focused vision of the continent." Questions about Africa's place in the current global literary marketplace "broaden some of the most urgent queries of the postcolonial era. Who gets to document African realities? Who are the 'gatekeepers' of African publishing traditions?"

On the ground the literary field is now far more forward-thinking and diverse. A wave of new or recently galvanised independent literary presses in the US and the UK are working in tandem with some of Africa's most generative outlets. Together they are publishing and promoting work by young and adventurous African writers. Books published originally by presses like Umuzi (South Africa) http://umuzi.bookslive.co.za/about/, amaBooks http://www.amabooksbyo.com/ (Zimbabwe) or Kwani http://kwani.org/ (Kenya) "find second lives with international publishers working to defy the constraints of profitability." Thus books that offer a decidedly more locally textured experience than those of the 'Afropolitan' rock stars have made their way abroad through small, focused channels. There is more to both African literature and Western publishing than meets an eye too practised in its suspicion, the author argues, and "if literature is doomed only to echo the failings of globalisation, then why bother? On the contrary, a new generation of writers and publishers deserve our awareness of the 'global literary marketplace' as a meaningfully multidimensional space."

\section{Mulgrew, Nick An Open Letter About our Submissions Period.}

http://uhlangapress.co.za/blog/2017/5/2/an-open-letter-about-our-open-submissions-

period (Posted 10 May 2017) [31/10/17]

uHlanga http://uhlangapress.co.za/ is a small poetry press based in Cape Town committed to publishing new, experimental and classic works of Southern African poetry. Early in 2017 it hosted its first-ever open submissions period for original manuscripts of poetry in South African languages. It received far more submissions than expected, with 119 poets sending in eligible work. In this informative posting Nick Mulgrew shares some insights what they learnt from the submissions period, offering some advice to new writers, as well as for many of the writers who weren't successful with their submissions. While the high volume of submissions seemed encouraging for the health of poetry writing in South Africa, analysing the submissions presented a more complicated picture. The vast majority of submissions were made in English, or predominantly in English. Although submissions were open in certain African languages, very few submissions in Zulu and Xhosa (and none in Sotho) were sent in. A small amount of submissions in Afrikaans, or predominantly in Afrikaans, were also received. 
For me, Mulgrew says, "these facts point to a couple things. First, uHlanga likely does not have a reputation for quality publishing in languages other than English. Afrikaans writers will most likely go for Afrikaans presses. This is understandable - the Afrikaans literary industry is relatively healthy in this regard. More important (and worrying), however, is our inability to attract more writers in African languages. The lack of African language submissions suggests one of two things: either there are few writers in African languages, or uHlanga failed to engage and make accessible our opportunity to people who write or would like to write in African languages. ... Although many writers are reticent to write in African languages, much of this reticence is down to a perceived lack of opportunities for publication or appreciation. The point, then, is to make more opportunities available, and to be consistent with offering them." Moreover, he adds, "the fact remains: Aspiring poets want people to read their poems without reading other people's poems. How do I know this? Two reasons. First, sales numbers don't add up. Second, aspiring poets aren't reading contemporary poetry. ... If you do not engage with your contemporaries, you cannot influence anything. This is why I would say - and this might be an unpopular opinion - that the work of transforming poetry publishing and appreciation in South Africa isn't the sole domain of publishers. It's the task of readers, and readers who are writers."

\section{Oxford Africa Initiative An Interview with James Currey. http://www.afox.ox.ac.uk/news/interview-with-james-currey/ (Posted 22 March 2017) [19/09/17]}

James Currey, co-founder of James Currey Publishers, has been called 'The Godfather of African Literature'. His publishing house, founded in 1984, has produced a very large number of academic books about Africa and African studies. Prior to setting up his own publishing firm he, together with Chinua Achebe, was the editor in charge of the African Writers Series (AWS) at Heinemann Educational Books from 1967 to 1984. In this interview he speaks not only about his publishing work, but also his life before, around and outside publishing. For a fuller account of Currey's association with the AWS series, read his fascinating and highly entertaining account Africa Writes Back: The African Writers Series $\mathcal{E}$ the Launch of African Literature*, in which he tells the story of how they did it, and how publishing relationships were developed and nurtured with a very large number of African authors, including some of the continent's now foremost writers.

*Note: for a review of Africa Writes Back see

https://www.academia.edu/2643961/James_Currey_Africa_Writes_Back_The_African_Writers_Series_and_the _Launch_of_African_Literature

\section{Oxford Africa Initiative Interview with Nana Ayebia Clarke MBE.}

http://www.afox.ox.ac.uk/news/interview-with-nana-ayebia-clarke-mbe/ (Video recording 11:25mins, posted 01 August 2017) [19/09/17]

In this video recording Ghanaian born publisher Nana Ayebia Clarke speaks about her work and career in publishing, first as the acquisitions editor of Heinemann's African \& Caribbean Writers series for 12 years (through to 2003, when the Heinemann management announced that no new titles would be added to the series and the Heinemann International Division was disbanded), thereafter with her own publishing firm Ayebia Clarke Publishers, cofounded with her husband David, and which has published and promoted many prominent 
African writers. She also speaks about the development of her list at Ayebia Clarke, her authors, and offers her thoughts on the publishing industry in Africa today.

Suhr-Sytsma, Nathan "Mbari Publications and the CIA." In Poetry, Print, and the Making of Postcolonial Literature by Nathan Suhr-Sytsma. Cambridge: Cambridge Core, Cambridge University Press, 2017, 60-74.

https://doi.org/10.1017/9781316711422

The Mbari Artists' and Writers' Club was established in Ibadan in 1961 as a hub for writers, artists and intellectuals, and its initial members included Ulli Beier, Wole Soyinka, Christopher Okigbo, J.P. Clark, and the South African writer Ezekiel Mphahlele, among others. In addition to a variety of cultural activities, and staging theatre productions, it acted as a publishing house and published the early works of many African writers who are now icons of African literature, as well as being involved in the publication of the literary and cultural journal Black Orpheus. Together with Onibonoje Press \& Book Industries Ltd, Mbari was among the very first indigenous publishers in Africa, and enjoyed a good measure of success. As Nathan Suhr-Sytsma points out, "the historical irony is that as the Mbari writers sought to escape the orbit of the colonial university, the local publication venues to which they turned were surreptitiously funded by another global power: the United States. Both Black Orpheus and Mbari Publications unwittingly received substantial monies from the Central Intelligence Agency through grants from the Congress of Cultural Freedom (CCF)." However, the author's own interest "is not so much in unveiling how these writers were 'coopt[ed]' by the CCF, as some recent work has tried to do, but in questioning the assumption that people can do valuable cultural work only when free from determination." And that, despite the covert funding, it could be argued that the Mbari writers strategically used the support of the CCF to "advance their own striking visions of the world." So was the joke on the writers or on the CIA? "Much as the CIA may have liked to produce an African intelligentsia that uniformly welcomed American interests, its cultural initiatives often had the effect of reinforcing the de-facto independence of the institutions and individuals it supported."

While the CIA underwrote, however covertly and indirectly, the artistic and literary flourishing associated with Mbari, the author concludes, "neither the world literature paradigm of writers who transcend their nations of origin, nor a countervailing emphasis on 'authentic subjectivity' quite captures the Mbari writers' Nigerian-based but non-nativist position, or the capacity they enjoyed through Mbari Publications to engage local, national, pan-African, and transatlantic publics. To observe, in turn, that this nonmetropolitan publisher was as embedded in compromise and controversy as its metropolitan counterparts ought to heighten, rather than detract from, the interest of the remarkable work it fostered."

\section{Suhr-Sytsma, Nathan "The Extroverted African Novel and Literary Publishing in the}

Twenty-first Century." Journal of African Cultural Studies

Published online 09 November 2017.

https://doi.org/10.1080/13696815.2017.1400953 [30/01/18]

This essay revisits Eileen Julien's paper, “The Extroverted African Novel” (2006), by way of twenty-first-century fiction by Nigerian writers. Since 2006, new Nigerian publishers have been publishing ambitious literary fiction that is arguably neither 'extroverted' nor 
'introverted', but 'multifocal'. Some new literary publishing firms in Nigeria are flourishing, and an increasing number of writers now have a preference for publishing within Nigeria.

New Nigerian-based literary publishers are significant for writers and their publics, the author posits, "because they mitigate the pressure on Nigerian writers to pitch their work to an 'extroverted' public if they are to enjoy the prestige and relative permanence of print publication. In order to work through these issues, this essay sketches the trajectory of literary publishing in Nigeria in light of questions about the 'forms of local immediacy' afforded by different genres and media." It also considers how the multifocal fictions of Sefi Atta, Teju Cole, Emmanuel Iduma and Abubakar Adam Ibrahim, among others, figure in literary publishing in Nigeria. "Their novels suggest that these writers' real investment in various readerships on the continent, as well as beyond it, goes hand in hand with their experience of literary singularity in the medium of print. In sum, locally published fiction can court multiple kinds of publics, and it may be more accurate to conceive of 'extroversion' as dependent on a text's reception than as fixed in its form."

\section{Book and journals assistance and donation programmes}

\section{Abrams, Dennis Books for Africa Reports its Largest Year in Shipped Copies. https://publishingperspectives.com/2017/08/books-for-africa-record-year-of-shipments/ (Posted 02 August, 2017) [14/08/17]}

Books for Africa, the book charity based in St. Paul, Minnesota, has announced that in a record-breaking year, more than 3.1 million educational, library, and law books have been shipped to 18 African countries, a 26-percent increase over last year. Top recipients were Ethiopia: 462,000 books, Nigeria: 319,000, Kenya: 308,000 books, Ghana: 242,000. Executive director Patrick Plonski is also quoted as saying: "Despite the 39 million books [delivered so far], we still have a lot of work to do to end the book famine on the continent." In a comment posted about this story [which for some reason has now been removed by Publishing Perspectives], Holger Ehling (formerly with the Frankfurt Book Fair) wrote: "This is very bad news indeed. Every single book shipped into Africa undermines efforts to create a sustainable African publishing industry. Every single book shipped into Africa and donated to libraries is a book not produced by African publishers and printers, not written by African authors, not sold and distributed by African booksellers. This is not a way to end the book famine in Africa. It is a surefire way to make it last." Plonski responds by saying "I agree with your [Ehling's] assessment that ultimately the solution to the shortage of books in Africa is enhanced published [sic] and book development in Africa. Regretfully, that may not happen until enhanced economic development allows for more robust public sector financing allowing for more local book purchases by ministries of education."

Patrick Plonski is talking about a situation he calls 'ultimately', but says nothing about the presence. What he and Books for Africa do not apparently wish to address are the negative consequences today, of overseas book aid organizations shipping tens of millions of free books annually to African libraries and schools. These negative consequences - as pointed out by various independent commentators in recent articles - relate to the weakening of the viability and prosperity of African publishers through limiting their reach into their own markets for which they are publishing. Supplies of donated books from overseas can significantly suppress demand for locally published books because many African 
governments rely on overseas book charities to fill book shelves in schools and libraries, and which has created a huge culture of culture of dependence on overseas book donation programmes. Meantime many high quality, culturally relevant books published locally may remain stacked in African publishers' warehouses while huge quantities of externally donated books are distributed to libraries because they are free.

Book Aid International Inspiring Readers. Bringing a World of Reading into the Classroom.

https://www.bookaid.org/aboutus/our-work/programmes/inspiring-readers/ [10/11/17]

'Inspiring Readers' launched by Book Aid International (BAI) in 2016 seeks to benefit 250,000 African primary school children. By providing Book Box Libraries to primary schools, and training for teachers in bringing the books to life in the classroom, it hopes to improve the reading opportunities of a quarter of a million children in Africa. 'Inspiring Readers' is currently underway in Kenya, Cameroon and Malawi, and BAI hopes to expand to other African countries soon. Over the next four years 310 primary schools will each receive a Book Box Library packed full of brand new, carefully selected books. BAI reports that each school will receive 1,250 new books, including locally published titles, and teachers from each school will have the opportunity to attend training with their local library to help them make the most of the books it sends, and bring them to life in the classroom. BAI says "Inspiring Readers not only brings books into schools but encourages children to use their local library. We use public and community libraries with Children's Corners as hubs for schools in the surrounding area, giving children access to larger book collections, vibrant library spaces and the passion and expertise of their local librarians. The programme will be closely monitored throughout and we will continue to support the schools involved."

\section{Chebon, Philemon Traditional Librarianship and the Changing Roles of Information} Professionals: From Issuing to Donating Books.

http://www.parliament.go.ug/aplesa/wp-content/uploads/2015/08/Traditional-

Librarianship-and-the-changing-roles-of-Information-Professionals.pptx [28/03/17]

A PowerPoint presentation contributed to the 16th Association of Parliaments Libraries of the Eastern and Southern Africa (APLESA) conference in Nairobi in April 2015. It sets out the challenges facing African libraries, funding for libraries and their place in national development plans, and also discusses the issue of book donation programmes. In his recommendations for future book donation activities and practices, the author says, among other recommendations, that donations should be limited to high-quality, recentlypublished materials, should be coordinated by individuals or groups with first-hand knowledge of the receiving communities, should identify the needs of the beneficiaries in order to match books with end users, and that there should be provision of funds to permit local purchases of books. Additionally there should be legislation to guide the donation of books and "use of standardized formats to carry out monitoring and evaluation of the programmes in order to ensure consistency in reporting."

Flaherty, Mary Grace “Thinking Twice Before Donating: 'We Don't Want Other People's Rubbish'". IFLA Library Services to Multicultural Populations Newsletter, Summer 2017: 3. https://www.ifla.org/files/assets/library-services-to-multiculturalpopulations/newsletters/summer_2017.pdf [20/06/17] 
An American librarian while spending some time in Malawi on a Fulbright scholarship award had opportunities to visit all types of libraries in that country: academic, school, and community based. During her visits, she found that many of the books in collections were donations shipped by book aid organizations, but did not fit the scope of any of the collections and were discards from libraries overseas. "While the gifts signify a lovely spirit of generosity and willingness to help, it takes a considerable amount of resources to ship them, such as the staff time to get them ready for shipping, the physical resources (boxes, labels), and, of course, the shipping itself. Whether they come by land, sea or air, books are heavy and expensive to transport." As the headmaster in one of the schools she visited aptly put it, "It's nice they send the stuff, but we don't want other people's rubbish." Flaherty goes on to suggest: "Don't put anything in a box to send overseas that has been withdrawn because it can't withstand circulation and don't put anything in a box to send overseas because it is outdated. When the need for generosity arises, we should consider working directly with individual libraries in a deliberate and measured way to send new or lightly used items by using wish lists, or sending a donation so they can procure for themselves what they deem as appropriate. Rather than using funds and resources to ship old books around the globe to foist upon under-resourced libraries, we should be supporting local and regional authors and publishers through organizations such as the African Books Collective $(\mathrm{ABC})$, a great resource for procuring books by local and regional authors."

Schaidler, John "Gizo-Gizo: A Tale from the Zongo Lagoon." International Leads. A Publication of the International Relations Round Table of the American Library Association 32, no. 4 (December 2017): 1-3.

http://www.ala.org/rt/sites/ala.org.rt/files/content/intlleads/leadsarchive/201712.pdf [09/01/18]

"This is the story of a group of highly imaginative, eager young students from Cape Coast, Ghana without access to any books that were specifically written for them and how they did something about it". John Schaidler of The Zongo Story Project http://www.zongostoryproject.com/ precedes his article with this observation: “Children's literacy and children's library programs in Anglophone West Africa are fraught with numerous problems. One of the most pervasive and enduring challenges is the persistent lack of access to high quality, culturally appropriate books and other learning materials. Ironically, a popular and widely enacted solution inadvertently helps to perpetuate the very same problem it seeks to end. By constantly framing and addressing the lack of books as a crisis, in-country and international stakeholders and key decision makers conclude that any books are better than no books, unconsciously laying the foundation for a cycle of dependence on foreign book aid. For nearly half a century, UK and US based book donation programs have been a bedrock strategy for raising literacy rates in English speaking African countries. Donor organizations breathlessly proclaim, 'Send a book, change a life,' and the public happily obliges, packing up secondhand copies of everything from Diary of a Wimpy Kid to Dan Brown's The Da Vinci Code and sending them thousands of miles to 'help feed hungry minds' in 'book-starved' Africa. Setting aside for a moment the utter lack of agency and victimhood that such language implies, the ubiquity of donated, repurposed or simply discarded books from the US and UK continues to impact or even define virtually every educational program in West Africa despite a growing body of evidence that details negative impacts." 
The Zongo Story Project - which springs directly from the local concerns of the Cape Coast Zongo community, a minority and historically marginalized Hausa settlement in Ghana believes that locally curated, culturally appropriate learning materials in which children "see themselves" yield better results. It strives to elevate proficiencies in oral, written, and visual forms of literacy; promote the knowledge building of local history, local culture and local contemporary concerns; and lay the crucial foundation for the acquisition of vital twenty-first century critical thinking skills. The conceptual framework for the project originated out of a larger, community-based initiative called the Zongo Water Project, whose mission is to use water as a way to improve the quality of life for the Zongo. Working closely with local teachers, Emily Williamson (who leads the Zongo Story Project together with John Schaidler) carried out a series of educational workshops at the Hassaniyya Quranic School in the summers of 2012, 2013, and 2014 to teach students about local water and environmental concerns. Employing the story as the foundational element, she engaged students in dialogue, shared readings, performances, writing exercises, and visual art, culminating in community drama performances and original folktales. The illustrations and text of this book grew directly out of the work produced in these workshops. The misadventures of Gizo Gizo - the lazy, selfish, greedy trickster of Hausa oral tradition - tells the tale about three best friends: Crab, Tortoise and Spider who live near the peaceful Zongo lagoon. One day, greedy Spider starts polluting the lagoon. When his friends tell him to stop because the animals are getting sick, he ignores them and even starts his own mining company to get rich. Finally, Crab and Tortoise come up with a plan to teach Spider a lesson he will never forget .....

Note: for more information about the Zongo Story project see also http://www.emilyannewilliamson.com/thezongo-story-project-1/. The award-winning Gizo-Gizo! was published by Sub-Saharan Publishers, Accra, and is distributed outside Africa by African Books Collective http://www.africanbookscollective.com/books/gizo-gizo.

\section{Book fairs and festivals}

International Publishers Association Global Book Fair Report 2017. https://www.internationalpublishers.org/images/industrynews/2017/IPA_Global_Book_Fair_Report_2017.pdf [05/04/17]

The IPA's Global Book Fair Report is an the annual compendium of world book fairs that complements the IPA International Book Fair Calendar, and aims to provide insider insights and interviews with the people behind the events. It is split into geographical regions: the Americas, Africa, Asia /Oceania, Europe, and the Middle East/Central Asia, and in the 2017 report there are 'Special focus' pages on Nigeria and the Nigeria International Book Fair, and Egypt and the Cairo International Book Fair. The Nigeria focus pages includes an interview with Gbadega Adedapo, CEO of Rashmed Publications http://rasmedpublications.com/ and Current President of the Nigerian Publishers Association http://nigerianpublishers.com/, discussing issues such as the structure of Nigeria's book market, Nigerian reading habits, the ratio of local vs. imported foreign books, recent developments in fighting piracy and enforcement of copyright, and the use of e-books and mobile devices. On the latter topic Adedapo says: "E-books and reading on mobile devices are at the introductory stage and the adoption by publishers is gradually improving. It is perceived that embracing e-books might increase piracy and undermine intellectual property protection. Secure management of e-books is perhaps one of the main concerns of publishing firms, and is consequently thought to be delaying adoption. The e-book market is 
just emerging. Some publishing houses have it at experimental stage while its adoption in an e-book pioneering state such as Osun raised sustainability questions."

Malec, Jennifer Abantu Book Festival Focuses on Legacy: Libraries, Free Books for Children, and Plans to Rotate Around South African Cities (Posted 08 December 2017) [11/12/17]

https://johannesburgreviewofbooks.com/2017/12/08/the-jrb-daily-2017-abantu-bookfestival-focuses-on-legacy-libraries-free-books-for-children-and-plans-to-rotate-aroundsouth-african-cities/.

Founded by novelist Thando Mgqolozana in 2015, the Abantu Book Festival http://www.abantubookfestival.co.za/index.html is an annual book fair and cultural eventcum-festival for black writers and readers, held in Soweto and designed "to celebrate the rich and diverse literary heritage emerging from the African continent." This is a report about the 2017 festival, which the organizers are contemplating of rotating around South Africa in future years. For the first time this year, Abantu featured a children's programme, curated by celebrated children's book author, story teller, and performer Gcina Mhlophe, and every child that attended was given a free book, in their home language. Libraries were another focus at the 2017 festival, including a workshop for librarians entitled 'Turning the Library in Africa into a truly African Library'. In his opening address Mgqolozana restated Abantu's core values: "This remains a book festival for black writers and readers. And this is not controversial, this is a fact. I don't think we need to overstate the reasons for it, but it's something that I want to say on this platform, to put out there one more time. Black writers and black readers are the people we are going to centre in our every activity."

Wikipedia. Book Fairs in South Africa.

https://en.wikipedia.org/wiki/Book_fairs_in_South_Africa [12/01/18]

Book fairs and literary festivals are held throughout South Africa each year to promote literacy and the reading habit among children and adults. This is a useful (2017) overview of them, providing short profiles of seven fairs and festivals, with links to their websites, as well as a number of links to newspaper articles reporting about these events.

\section{Book prizes and awards}

Murua, James Throwback Thursday: The Noma Award for Publishing in Africa. http://www.jamesmurua.com/throwback-thursday-noma-award-publishing-africa/ (Posted 06 April 2017) [25/04/17]

A short account of the Noma Award for Publishing in Africa, together with a complete list of past winners. Generously supported by the late Shoichi Noma of Japanese publishing giant Kodansha Limited, the award was open to African writers and scholars whose work was published in Africa, and thus was supportive not only of African writers and scholars, but also the African book industries. Now discontinued, it was given annually from 1980 to 2009 in three categories: creative writing, scholarly books, as well as children's books. It was the premier African book prize for almost three decades. 
Children's book publishing (see also $\rightarrow$ Publishing in African languages, $\rightarrow$ Reading culture and reading promotion)

Note: this sub-section includes primarily records that deal, in whole or in part, with the publishing aspects of producing children's literature. Articles that deal exclusively with writing for children are not included, nor are articles that focus on different genres in children's writing, storytelling, oral literature and culture, or those that examine themes and images in African children's literature.

\section{Bruckert, Danielle BookDash - Creative Commons Stories for Children.}

https://freekidsbooks.org/bookdash-cc-childrens-stories/ (Posted 03 January 2017)

[18/03/17]

Founded by Arthur Attwell, the not-for-profit Book Dash organization http://bookdash.org/ brings together creative professionals - writers, illustrators, designers, editors - who volunteer to create high-quality children's books that anyone can freely download, translate, print and distribute. Most of the work is done on a 'Book Dash day', when small teams work for over twelve straight hours, each producing a new book. In this interview with members of the Book Dash team they talk about their vision, their work, how they operate, and how they match writers with designers and illustrators to create these book-making teams.

Note: see also the Book Dash Manual at

https://docs.google.com/document/d/1oQB_9MFuthF2X9szm0i4aMRNMS_dtLgbkqmzko0zyhI/edit

Lever, Carla We Want African Stories to be Truly Accessible to all South African Children - a Q\&A with the Masterminds Behind Book Dash.

http://bookslive.co.za/blog/2017/09/12/we-want-african-stories-to-be-truly-accessible-toall-south-african-children-a-qa-with-the-masterminds-behind-book-dash/ (Posted 12 September 2017) [17/10/17]

A conversation with Book Dash http://bookdash.org/ co-founder Arthur Attwell and programme director Julia Norris talking about their activities, how they work, and raise funds. Book Dash brings together professional writers, illustrators, designers and editors to volunteer their time to create new, high-quality, African children's books, increasingly now also books in isiZulu, isiXhosa and Sepedi, thus fulfilling a gap in the indigenous language storytelling market. All the books are freely available through a free Android app.

Micomyiza, Isaïe Children's Book Industry in Rwanda.

http://akomanet.com/childrens-book-industry-in-rwanda/ (Posted 21 October 2016) [16/03/17]

A short account of the development of the children's book industry in Rwanda, and the principal publishers involved. As the author points out, the industry experienced a significant growth when the UK charity Save the Children started projects that aim at giving children access to quality books in their mother tongue. Since then, there has been a significant increase in the number of publishing companies dedicated to children literature. More than 20 publishing companies are currently operating in Rwanda, and children's books are a priority for almost all of them.

Nnyanzi, Nuwa Wamala Giving Form to Words for the Sake of Children. http://www.ucwia.or.ug/GIVING\%20FORM\%20TO\%20WORDS\%20FOR\%20THE\%20SA KE\%20OF\%20CHILDREN.pdf [19/12/17]

A paper presented at the 4th IBBY Africa Region conference, Rethinking Contemporary Literature for Children and Young People in Africa, Kampala, 22-24 August 2017. 
"African authored children's books have illustrations that have to a large extent not captured children's interests as have those from Europe and the US" declares Nuwa Nnyanzi, a multi-media visual arts practitioner in Uganda and founder of the Nnyanzi Art Studio in Kampala. Notable absences, he says, include celebrated African images from books by African writers despite the availability of many widely told folktales. "Many locally illustrated books are not inspired or informed by our artistic cultural and traditional values so as to make them endearing and easy to relate to." Importantly, it is the visual language for children that needs to be as appropriate as the written word, "if we are to make headway in attracting children to locally published books and keeping them interested", it is "the application, treatment and presentation of the subject matter that determines the effectiveness of the message at the end."

\section{Qualey, Marcia Lynx World Kid Lit: Nine African Children's Books by Africans.} https://www.bookwitty.com/reading_list/world-kid-lit-nine-african-childrens-booksby/59b0580350cef7429c6741ee [12/01/18]

African children's literature by African authors, the author claims, "is among the most underrepresented in UK and US bookshops ... Translations of African literature are about as rare as dragon's teeth, and can be just as hard to find." Here she provides a brief tour of African children's literature, as part of a month-long series on Bookwitty celebrating world literature for children.

Simpson, Muhwezi Problems Facing Children's Book Authors in Uganda: What Should Be Done?

http://www.ucwia.or.ug/Problems\%20Facing\%20Children's\%20Authors-1.pdf (Full text, pdf)

[19/12/17]

http://www.ucwia.or.ug/Problems\%20Facing\%20Children's\%20Authors.pdf (PowerPoint presentation)

A paper presented at the 4th IBBY Africa Region conference, Rethinking Contemporary Literature for Children and Young People in Africa, Kampala, 22-24 August 2017.

The lack of a sustainable reading culture, limited publishing opportunities, few libraries, low income levels and widespread poverty, and lack of a comprehensive government policy that supports and/or popularizes books, are some of the major problems hindering the growth and prosperity of children's book authors in Uganda. This paper is backed by the author's practical experience of self-publishing, but it also sought the views of other stakeholders such as authors, editors, publishers, booksellers and organizations, in order to assess the major issues and challenges, and make a series of recommendations how the situation might be addressed. "From colonial days, the Ugandan population has been relying heavily on imported books. Today, many libraries and bookshops are still suffocated with Western books; books which tell stories of white people. In schools, children are made to read foreign texts instead of texts about their culture, geography and history." Although a number of organizations have been established that actively promote indigenous literature, children's authors still lack an organization whose aim is to promote their work: "Amidst all the stumbling blocks associated with publishing in Uganda, such as high costs of production, and poor quality as in the case of self-publishers, strategic interventions must be made to ease access to professional publishing services. There is need to establish structures that 
refine talent, and to improve production, processing and distribution of children's books across Uganda and the African continent."

Note: More papers presented at the 4th IBBY Africa Region conference, Rethinking Contemporary Literature for Children and Young People in Africa, Kampala, 22-24 August 2017, can be accessed at the website of Uganda Children's Writers and Illustrators Association at http://www.ucwia.or.ug/ who were the joint organizers of that conference. The papers cover a wide range of themes and sub-themes, such as creating children's literature that make it engaging and attractive to children, effective design and illustration of children's books, the need for more local content in African-published children's books, translating children's literature in Africa, oral traditions and children's literature, children's books in African languages, and the need for research of African children's literature.

\section{Copyright and legal deposit/Authors' rights/Book piracy (see also $\rightarrow$ South Africa, $\rightarrow$ Open} access publishing and licensing)

Note: this sub-section is primarily confined to articles and papers that deal with copyright of books, the rights of authors, book piracy, and African perspectives on copyright. General articles on intellectual property rights, or intellectual property legislation in African countries, are not included here.

Gray, Eve Parallel Importation Prohibition and the 'Politics of the Copy' in Africa. http://graysouth.co.za/2017/07/31/parallel-importation-prohibition-the-politics-of-thecopy-in-anglophone-africa/ (Posted 31 July 2017) [18/09/17]

Also at http://ip-unit.org/2017/parallel-importation-prohibitions-and-the-politics-of-thecopy-in-africa/

Eve Gray offers her thoughts on the complex matter of the Copyright Amendment Bill of 2017 currently undergoing the consultative process in South Africa, and which proposes overturning the longstanding prohibition against parallel importation (essentially a product imported from another country without the permission of the intellectual property owner, or the free trade in books across borders) provided for in the present South African legislation, an action, Gray says, "that could undo more than a century of colonially-based market manipulation." She examines what this could mean in relation to the publishing industry - especially in Africa - and the international trade in books, and the implications in terms of the pricing of books, and greater accessibility to affordable publications for students and general readers. In student debates, for example, the questions that is often raised is why textbooks are very much cheaper in some countries than in South Africa, and why South African students are not able to buy these books in South Africa at these cheaper prices.

Gray explains some of the intricacies of parallel importation, and which might be described as a kind of protectionist holdover, which is still conventional commercial practice across international markets. In the case of books it refers to the granting of 'territorial rights' by one publisher to its own subsidiary, or to another publisher in a different country, in order to allow for differential pricing related to affordability in that particular market. (These rights are not in fact part of copyright law, but simply part of an international co-edition agreement by one publisher who approaches one or more overseas partners with a view to 
licensing the work to them, i.e. territorial licensing.) This means that, e.g. books made in one county under licence from a copyright holder, cannot be sold by booksellers, publishers or other individuals in a second country if that country has parallel import restrictions in its legislation, as is the case with most ex-British colonies. As result of restrictions on parallel importation, purchasers of the book in South Africa or in another African country will not be able to buy the much cheaper Indian edition of a UK or US textbook licensed, and selling at a much cheaper sales price in India.

In looking at the potential impact of these practices on publishing across Africa, Gray says "in Africa the market for books has been fragmented by decades of territorial licensing between African publishers and British and US publishers in order to get international market reach for the African publisher. If an African publisher has a title with potential in the wider market, it will most often be licensed to a UK or US publisher, who would claim 'rest of the world' rights, while other African countries would have to buy this UK 'world' edition rather than the original African edition. And so, in the 1990s, for example, the African Literature department at a local university often found itself having to license photocopies of prescribed novels by African authors, as they were simply not readily available in South Africa, or only on special order at unaffordable prices, because British publishers were often reluctant to bother with distribution in as small a market as South Africa, and also because the international edition was simply too expensive." Another discretionary practice was a British 'charitable' scheme for the provision of heavily discounted books into African markets, the Educational Low-Priced Book Scheme (ELBS). As a charitable initiative, these books were bought at wholesale prices from British publishers and sold in some African countries at very heavily discounted prices. This effectively undermined regional publishing, as publishers in many African countries were unable to compete with the low pricing levels.

In here concluding paragraph Eve Gray says: “Overall, it looks as though abolition of PIRs would be of benefit, rather than harming the book trade and its customers. In Africa, I would argue, it would almost certainly increase trade and broaden the reach of African books and other copyright goods across the continent. A detailed study of this tangled web is well overdue."

Note: for another perspective on parallel importation, from a legal point of view, see http://www.internationallawoffice.com/Newsletters/Intellectual-Property/South-Africa/KISCH-IP/Is-parallelimportation-lawful

\section{Digital media and electronic publishing}

CNBC Africa Longhorn Publishers' Simon Ngigi Outlines Digital Growth Strategy. https://www.cnbcafrica.com/videos/2017/05/10/longhorn-publishers-simon-ngigi-outlinesdigital-growth-strategy/ (Video 5.17mins. Posted 10 May 2017) [09/09/17]

Kenyan publishing company Longhorn Publishers is pegging future growth on the distribution of digital academic content in several countries in East and Southern Africa. Here its Managing Director, Simon Ngigi, talks about the challenges and prospects of digital publishing, the diversification programme his company is going through in gradually migrating to digital, and the encouraging growth thus far of income through digital products, embracing a variety of areas of the Longhorn list such as dictionaries and 
reference works, atlases, religious books, hymn books and bibles; as well as its mainstay of publishing for the tertiary markets. One factor unfavourably impacting on further growth is the high $16 \%$ VAT currently imposed on books. Ironically the government is a major investor in education but then the Treasury takes this amount back, thus "taxing knowledge", and which has negatively affected sales of children's books in particular.

de Mutiis, Anna, and Stephanie Kitchen "African Digital Research Repositories: Survey Report." Africa Bibliography Volume 2015, (2016): vii-xxv. https://www.cambridge.org/core/journals/africa-bibliography/article/div-classtitleafricandigital-research-repositories-survey-reportdiv/9A7DBCF943E9710652ED190968D437E5 [01/03/17]

Institutional repositories are an increasingly significant component in the provision of academic publication and information resources. They are being developed throughout the world as a consequence of the availability of scholarly resources in digital formats, and in response to open access policies and mandates. To gain a better sense of the existing institutional repository landscape in Africa, the International African Institute (IAI) first collated and published on its website an inventory of all known institutional repositories in 24 African countries http://www.internationalafricaninstitute.org/repositories.html (there are no known depositories in 27 other African countries.) It thereafter conducted a survey among a selected number of repositories listed on the IAI website, approaching more than 50 institutions (mainly university libraries), with questionnaires in English, French and Portuguese. A total of 18 institutions and universities responded to the survey, whose responses are analysed in this report. Following a general analysis of the results, this includes a description of the range of activities of each repository, such as details of collections, size of holdings, disciplines covered, hosting and software used, copyright policies employed, and open access policies, together with full contact details, links to websites and OAI-PMH (Open Archives Initiative Protocol for Metadata Harvesting).

In a concluding comment the authors set out the inevitable limitations of this initial study, for example that it has not addressed at any meaningful level the 'demand' (e.g. from researchers) for repositories, nor the scale or quality of the materials contained therein, nor their formats or user-friendliness. At an operational level, questions remain about restrictions on access, fears of plagiarism and concerns about copyright. Authors may be concerned about being able to publish materials placed in repositories elsewhere in journals or books. "The authors of this study fully acknowledge these complexities. But repositories as sites for storing research materials, in particular university theses, in Africa as elsewhere, will be with us for the future and therefore will impact on researchers' publication and dissemination strategies and be used increasingly as research tools. Those interested in Africa's changing research, publishing, institutional and library landscapes need to take note."

Kaabwe, Melvin "A Veritable Smorgasbord. Digital Sector Report." Bookmarks Issue 90 (Sep.-Nov. 2017): 12-13.

https://www.sabooksellers.com/wp-content/assets/BookmarkIssue90.pdf [20/10/17]

Reports about recent moves in the digital area, e-book space, and developments of ecommerce channels in South Africa, and especially as they affect the retail trade in that country. "The impact of digital technologies continues to be felt by booksellers. It is no 
longer a fear of digital taking over as it is a necessity for traditional bricks and mortar operations to adapt to the changes brought on by digital in terms of customer expectations." E-commerce channels of booksellers is trending towards more mobile access, and some new developments have led to up to $50 \%$ of browsing being done via mobile devices. All of this, the author says, "makes for a compelling case for booksellers to prime themselves for continuous public interest in e-learning materials including supplementary content like revision aids in electronic format."

Kangethe, Kennedy Longhorn to Spend Sh200Mn to Digitize Books in New Digital Strategy.

http://www.capitalfm.co.ke/business/2017/07/longhorn-bets-on-digital-publishing-togrow-business/ (Posted 25 July 2017) [30/09/17]

Reports about Longhorn Publishers http://longhornpublishers.com/ke/ plans to set aside KSh200 million (ca. US\$ $2 \mathrm{~m}$ ) to convert physical books to digital formats in anticipation of the roll out the government's digital learning programme, the ICT Integration in Primary Education - Digital Literacy project. It plans to spend a further KSh50 million annually on marketing the new digital projects. The components of the project include improvement of ICT infrastructure, development of digital content, capacity building of teachers, and procurement of ICT devices.

Leonard, Anna The Views, Adoption and Use of E-books by Undergraduate Students at the University of Namibia.

http://uir.unisa.ac.za/bitstream/handle/10500/23180/dissertation_leonard_a.pdf.pdf?seque nce=1 [18/12/17]

Pretoria: University of Pretoria, MA dissertation (Information Science), 2017. 213 pp.

The advancement of ICT, especially the rapid spread of the Internet, which makes information more widely available to more people, has brought about significant changes to the publishing industry, including the rise of electronic information sources such as ejournals and e-books. The research presented in this meticulously documented dissertation aims to shed light on the use and adoption of e-books at the University of Namibia. The results of the study revealed a high awareness about e-books by students, as well as frequent general use of e-books. The study, the author reports, also observed positive attitudes towards e-books by students, "as they indicated a preference for e-books over printed books and reported using e-books mainly for course work and research purposes." However, "in identifying factors that hinder the use of e-books, aspects such as slow Internet connections, lack of knowledge (including the awareness and skills required to utilise e-books), limited and/or lack of relevant e-books titles, preference for print, eye strain and difficulty reading on screen, as well as limited computers and lack of e-readers, were identified as major deterrents for the use of e-books."

Secorun, Laura Kenya's Tech Startups Trial Digital Classrooms in Drive for Literacy. https://www.theguardian.com/sustainable-business/2017/jan/23/tech-startups-kenyabridge-education-gap?CMP=Share_AndroidApp_WhatsApp [28/01/17]

With limited Internet access and regular power outages in schools, will digital education companies be able to transform learning in East Africa? Kenya is brimming with companies trying to bring education into the digital era by scanning textbooks, developing bite-sized courses for mobile phones and providing tablets to rural schools. And Kenya's Ministry of 
Information, Communications and Technology is rolling out a Digital Literacy Programme, which promises to deliver $1.2 \mathrm{~m}$ devices to all of the country's 21,718 public primary schools by the end of 2017. However, only a third of Kenyans have access to the Internet and many schools often suffer from regular power outages, which makes it difficult to charge the devices. That is why BRCK-Education https://www.brck.com/, a Nairobi tech company, has developed the Kio Kit. This portable digital classroom includes a Wifi hotspot, a small server packed with educational content, and 40 tablets that can be charged wirelessly, and which they claim will work even in the roughest conditions in rural schools.

However, devices and gadgets alone are unlikely to bridge the digital divide in Kenya's education. One Laptop Per Child - a not-for-profit organization providing low-cost computers to children around the world - once had similar aspirations and was active in over 30 countries, before downsizing, the author reports. Even with public support, questions remain about how effective digital classrooms are, and empirical evidence on their academic merits is still scarce. A large-scale study by the International Initiative for Impact Evaluation concluded that computer-assisted learning had "decidedly mixed effects", depending on the context, see http://pubdocs.worldbank.org/en/429341481774674870/TheImpact-of-Education-Programmes-on-Learning-and-School-Participation.pdf

Wiese, Melanie, and Giselle Du Plessis "Emerging Technologies: E-Textbooks, One Piece of the Puzzle." Africa Education Review 14, no. 2 (2017): 15-36.

http://www.tandfonline.com/doi/abs/10.1080/18146627.2016.1271281 [18/09/17]

The Internet has not only brought about a new technological era, but also seen the introduction of a number of emerging technologies such as e-textbooks. However, the slow acceptance of e-textbooks is an issue of concern. The objective of this study was to investigate students' perceptions and use of e-textbooks (at the University of Pretoria in South Africa.) Data was collected by using a self-completion questionnaire and a focus group discussion. "The results showed that the two major obstacles identified in literature in adopting e-textbooks, access to electronic devices and the lack of computer skills, were not an issue of concern in this study. Unfortunately, the results of this study show that although students are positive about e-textbooks, this positive attitude does not necessarily result in high usage. This has real implications for academics, as the challenge will be to encourage students to try out e-textbooks by incorporating this as part of a pedagogical model, whilst providing safeguards against academic risks." [From the abstract, not examined]

\section{Worldreader. 2016 Annual Report.}

https://www.worldreader.org/2016-annualreport/?utm_source=newsletter\&utm_medium=email [30/06/17]

Reports about the accomplishments of the Worldreader organization https://www.worldreader.org/ during the course of 2016. This includes the successful completion of two of Worldreader's largest school-based projects, the Tusome Early Grade Reading Project in Kenya, and the Education Sector Support Programme in Nigeria. In another project in Kenya, Worldreader partnered with the Kenya National Library Service to launch LEAP 2.0, a project that will aim to bring digital reading to all 61 public libraries in Kenya by December 2017. In 2016 it also launched Anasoma, a new two-year research project "that seeks to understand how books can empower women and how we can encourage more women to read using their mobile phones." The project is funded by the Bill 
and Melinda Gates Foundation, and "seeks to identify what women want to read and how to better reach them so they too can be a part of the digital reading revolution." Finally, Worldreader also reports about a new project that will focus on skills-based literacy development. In order to contribute to the advancement of 2030 Sustainable Development Goals, "Worldreader aims to work with local literacy-based organizations to reinforce their efforts of scaling up functional literacy levels among youth and adults by adopting Worldreader's skill-based literacy approach. This approach seeks to combine the learning of a useful skill with the knowledge of literacy via mobile phones."

\section{Educational and school book publishing (see also $\rightarrow$ Children's book publishing $\rightarrow$ Digital media and electronic publishing)}

Attwell, Arthur Institutional Licensing: the Next School-Textbook Business Model. https://medium.com/@arthurattwell/institutional-licensing-the-next-school-textbookbusiness-model-befb1f70c212

(Posted 11/07/17) [18/09/17]

For years in South Africa, the author says, the textbook-publishing industry has been confronted with real threats to its future, "because - faced with non-delivery of books government is desperate to change the way it buys them. Other countries face similar challenges. Government officials often cite the 'high price of books' as a key issue. Whether you buy the state's argument or not, the system is going to change, and publishers can either lead the change or be changed." To have any real effect, he argues, the change must be a fundamental change in the mainstream textbook business model: "Instead of selling copies, we must sell licences. Specifically, we must sell licences with no limitations on the number of downstream copies. This is especially urgent and appropriate for school books, though it'll work for universities and colleges, too. And it's perfectly suited to a world of tablets and e-books. Best of all, it will save government money and make publishers' jobs simpler." In this article he describes his proposed model in some detail, but adds a caveat: "To become reality, institutional licensing for textbooks requires a special kind of alchemy: perfect timing. The state must phase in a licence system at a time that fits with curriculum change and book publishing timeframes."

Maistry, Suriamurthee Moonsamy, and Roshnee David "Phantasmagoria: Communicating an Illusion of Entrepreneurship in South African School Textbooks." Educational Research for Social Change 6, no. 2 (September 2017)

http://dx.doi.org/10.17159/2221-4070/2017/v6i2a7 [28/01/18]

The textbook industry, the authors argue, is essentially a profit driven industry that has to meet the very specific needs of its target market. In the South African context, the state is the most powerful player in this market because it provides the regulatory frame for textbook production as well as performing a quality assurance and content vetting role. In this article they examine "discourses of entrepreneurship manifest in selected textbooks used in South African primary schools in the post-apartheid era." While the authors acknowledge that an attempt has been made to purge school textbooks of biased or pejorative subject matter, "the extent to which new powerful discourses have replaced apartheid ideology remains unknown"; and there is little dispute, they say, that school textbook content can communicate subliminal messages about the world. Using critical discourse analysis, the authors "reveal constituted and constitutive ideology at work in the textbooks under study. 
A dominant discourse that emerged was that individuals in society are responsible for their own economic sustainability despite prevailing and historic conditions of oppression and subjugation, and that entrepreneurship is a readily viable way to achieve economic emancipation because it naturally leads to wealth creation. It communicates as a subtle yet deliberate attempt by the state to displace its responsibility for the economic welfare of the individual citizen. The textbooks uncritically legitimate the values of the neoliberal market system. In this paper, we urge the development of a heightened sensitivity when teacher educators, teachers, and learners engage with such ideological persuasions." [From the abstract]

\section{Milligan, Lizzi O. Accessible, Engaging Textbooks Could Improve Children's Learning.} https://theconversation.com/accessible-engaging-textbooks-could-improve-childrenslearning-74175 (Posted 15 March 2017) [18/06/17]

Textbooks are a crucial part of any child's learning. A large body of research has proved this many times and in many very different contexts. But, the author says, there's an elephant in the room when it comes to textbooks in African countries' classrooms: language. Rwanda is one of many African countries that has adopted a language instruction policy which sees children learning in local or mother tongue languages for the first three years of primary school. They then transition in upper primary and secondary school into a dominant, socalled 'international' language. This might be English, French or Portuguese. In Rwanda, it has been English since 2008. "Evidence from across the continent suggests that this transition point, many learners have not developed basic literacy and numeracy skills. And, significantly, they have not acquired anywhere near enough of the language they are about to learn in to be able to engage in learning effectively. ... The arguments for mother-tongue based education are compelling. But it's important to consider strategies for supporting learners within existing policy priorities. Using appropriate learning and teaching materials - such as textbooks - could be one such strategy. It's not enough to just hand out textbooks in every classroom. The books need to tick two boxes: learners must be able to read them and teachers must feel enabled to teach with them." Milligan asserts that existing textbooks tend not to take these concerns into consideration. The language may be too difficult and the sentence structures too complex. She reports about a recent initiative in Rwanda* that has sought to address this through the development of 'language supportive' textbooks for primary 4 learners who are around 11 years old. These were specifically designed in collaboration with local publishers, editors and writers.

*Note: see Milligan, Lizzi O., John Clegg, and Leon Tikly Exploring the Potential for Language Supportive Learning in English Medium Instruction: A Rwandan Case Study

http://www.tandfonline.com/doi/abs/10.1080/03050068.2016.1185258?journalCode=cced20

Nsabimana, Jean De Dieu Rwanda: Education Board Moves to Create Publishing House for Textbooks.

http://allafrica.com/stories/201712280418.html (Posted 27/12/17) [28/01/18]

Local publishers in Rwanda have protested over a decision by the Ministry of Education, through its Rwanda Education Board (REB), to start producing textbooks to use in preprimary, primary and secondary education in the country, instead of relying on books produced independent private sector publishers. Stephen Mugisha, who is the chairman of the Rwanda Publishers and Booksellers Union http://kimulijoachim.wixsite.com/rwandapublishers, is quoted as saying "Publishers were 
supposed to write and sell the books to REB after its deep evaluation as a regulator of content, but now who will evaluate the content to ensure quality control? ... The decision also goes against the government agenda of empowering the private sector as the drivers of the economy. The nascent industry of local publishers now faces an eminent extinction."

Wepukhulu, Dorcas; John Ng'asike, Cornelius Gulere, and Tessa Welch The Contribution of the African Storybook Initiative to Content Development for Multilingual Literacy Development in Africa.

http://ucu.ac.ug/images/Research/Languages/ASb-Wepukhulu-Gulere-Ngasike.pdf [21/12/17]

African Storybook http://www.africanstorybook.org/ is an initiative of Saide, http://www.saide.org.za/, a South African NGO involved in open education projects across sub-Saharan Africa. Its principal mission is to address the shortage of contextually appropriate books for early reading in the languages of Africa. It provides digital open access to children's picture storybooks, together with creation and translation tools for users to help them make and publish their own storybooks. African Storybooks are licensed under a Creative Commons Attribution (CC-BY 4.0) licence. Story development workshops are held with educators and partner organizations where storybooks with local content are produced. This PowerPoint presentation describes its main achievements during its initial four years of operations from 2013 to 2016, sets out its methods of delivery, its wide-spread use with low print costs for printing at scale, and its involvement in other activities such as community libraries, reading camps, story-telling events, and various writing, translating, and editing activities.

\section{Intra-African book trade}

Musoke, Samuel Majwega One Market, Different Regulation. An Experience of Crossborder Book Trade in Africa.

http://www.ucwia.or.ug/Cross\%20border.pdf [19/12/17]

A paper presented at the 4th IBBY Africa Region conference, Rethinking Contemporary Literature for Children and Young People in Africa, Kampala, 22-24 August 2017.

Reports about the experience of MK Publishers Ltd https://mkpublishers.com/, a leading East African educational publisher with headquarters in Uganda, to develop and sell textbook materials across borders to educational institutions and government ministries in Rwanda, and the many challenges involved as they relate to different currencies, varying curricula, dissimilar bidding regulations and procedures, as well as different copyright policies. The author makes a number of recommendations how cross-border trade, currently riddled with numerous logistical problems and barriers, could be improved in the years ahead.

Journals and magazine publishing (see also $\rightarrow$ Open access publishing and licensing, $\rightarrow$ Scholarly publishing)

African Journals Online/INASP Guide to the Journal Practices and Standards (JPPS) Framework.

http://www.inasp.info/uploads/filer_public/72/99/729992fc-cdde-4ed4-8d8a-

0da3fbdc4003/inasp_-_jpps_standards_guide_-_eng_-_digital.pdf [08/12/17] 
(Also available in Spanish and French versions.)

Concerns are often voiced about the perceived quality and transparency of the publication processes for Southern journals, and this, in turn, limits the perceived credibility of the research published within those journals. Established and managed by African Journals Online (AJOL) https://www.ajol.info/ and the International Network for the Availability of Scientific Information (INASP) http://www.inasp.info/en/ the Journal Publishing Practices and Standards (JPPS) is a new framework for assessing publishing practices and standards of Southern (including African) journals. It is initially being used to assess the journals hosted on JOL platforms. As described in this guide, journals assessed against the JPPS criteria are given one of six levels: inactive title; new title; no stars; one star; two stars; and three stars. The assigned JPPS levels serve a dual purpose. For readers, they provide assurance that the journals meet an internationally recognized set of criteria at a particular level. For journal editors, the detailed feedback from the JPPS assessment helps them identify ways to improve their publishing practices and standards, with a view to achieving a higher level at the next assessment.

Note: see also the article by Siân Harris below.

Harris, Siân New Assessment Process Boosts Credibility of Developing-world Journals. https://scholarlykitchen.sspnet.org/2017/09/21/new-assessment-process-boosts-credibilitydeveloping-world-journals/ (Posted 21 September 2017) [17/10/17]

Reports about the work and activities of INASP, an international development organization dedicated to supporting the production, sharing and use of research and knowledge in the developing world including its Journals Online platforms http://www.inasp.info/en/work/journals-online/, a project that aims to improve the accessibility and visibility of developing-country research. By providing a cost-effective and secure platform for online journals, along with advice, resource guides and links to suitable technologies and hosting organizations, the Journals Online enable easy discoverability of the wide range of journals and research being produced in the relevant partner countries. including African Journals Online (AJOL) https://www.ajol.info/ the world's largest and pre-eminent collection of peer-reviewed, African-published scholarly journals. Initiated by INASP in May 1998 as a pilot project, AJOL has been run as an independent South Africabased entity since 2005, currently [October 2017] hosting 521 African-published journals, of which 221 are open access journals.

Siân Harris also reports about the launching of the Journal Publishing Practices and Standards (JPPS) project https://www.journalquality.info/en/, a new framework for assessing publishing practices and standards (see also preceding record above). The Journal Publishing Practices and Standards (JPPS) framework provides detailed assessment criteria for the quality of publishing practices of Southern journals and is initially being used to assess the journals hosted on JOL platforms.

Mwangi, Douglas Macharia Publishing Outposts on the Kenyan Literary Landscape: A Critique of Busara, Mũtiiri and Kwani? Nairobi: University of Nairobi, PhD thesis, 2015. 257 pp.

http://erepository.uonbi.ac.ke/bitstream/handle/11295/93291/Mwangi_Publishing\%20Out posts $\% 20$ on $\% 20$ the $\% 20$ Kenyan $\% 20$ Literary $\% 2$ Landscape $\% 20$ a $\% 20$ Critique $\% 20$ of $\% 20 \mathrm{Bus}$ ara, \%20M\%20tiiri\%20and\%20Kwani.pdf?sequence=3 [21/08/17] 
This study explores Busara, Mũtiiri and Kwani? as magazines that are representative of some defining moments in Kenya's literary history. Using a historical approach, the author relates literary production in Kenya to its socio-political contexts from the 1960s to 2014, discussing how early Kenyan literary magazines such as Busara participated in the establishment of foundational literary traditions in the country, and examining the roles that pioneer creative writers and critics played in setting the pace for later writers and critics. Additionally, the author evaluates the founding of Mũtiiri by Ngũgĩ wa Thiong'o in the US in 1994, and seeks to demonstrate "how the circumstances that gave birth to Mũtiiri also precipitated the founding of Kwani? in 2003." The study not only seeks to illustrate how literary journals and magazines are brooding nests for creative writers and literary critics, but "also shows how they nurture literary cultures, build bridges between generations of writers and between traditions, and even generate space, time and tempo for (new) literary trends." The study thus positions literary journals and magazines as publishing outposts that have made a significant contribution to the evolution and development of Kenyan literature over time.

\section{Remmington, Janet What are Publishers Doing about Global Divides?}

http://blog.inasp.info/publishers-global-

divides/?hootPostID=78db9704b1be794c7eac80af75b5506f (Posted 5 July 2017) [18/09/17]

Janet Remmington, Regional Director for Africa and Editorial Director for the global arts and humanities journals at Taylor \& Francis, gives an account of some of the work undertaken by Taylor \& Francis towards addressing information needs in the global South. This has included teaming up with African co-publishers, institutions, learned society journals, research communities, and other local partnerships. Areas of cooperation have also included discounted access arrangements for partner countries via national consortia, and author development in collaboration with AuthorAID. In 2014-2015, Taylor \& Francis cohosted research writing and publishing workshops in Eastern Africa, with participants from the Kenyan and Ethiopian events discussing the importance of author guidelines, the issue of predatory journals, and the availability of networks for preparing collaborative projects. To complement partner initiatives, Taylor \& Francis has been creating opportunities for reaching out virtually and in person, has supported conferences and events on the ground in many countries of the global South through its network of offices, and has convened an inhouse cross-departmental working group for developing-country initiatives to raise awareness, coordinate endeavours, and share experiences.

Smith, Ina Scholarly Journal Publishing in the Global South - Africa. https://www.slideshare.net/AfricanOpenSciencePlatform/scholarly-journal-publishingin-the-global-south-africa [SlideShare, 12/01/18] https://pkp.sfu.ca/pkp2017/paper/view/605/376 (Video presentation, 31:41mins)

A SlideShare/video presentation made at the sixth Public Knowledge Project (PKP) International Scholarly Publishing Conference held in Montreal in August 2017. If offers an overview of the current African scholarly journal landscape and describes various African approaches to scholarly journal publishing and is challenges. It examines different patterns of publishing, and issues such as low awareness of the benefits of open access, equally low awareness of publishing software such as OJS, commercial publishers vs. institutional publishing of African journals; an unhealthy reliance on the Journal Impact Factor, predatory publishing, the need for skills development and capacity building, financial stability, and the possible role of African Academies of Science. It concludes with a range of 
recommendations on the way forward in order to increase impact and visibility: "Open source software and the philosophy to which it subscribes offers great opportunities to publish high quality open access scholarly journals. The use of open source software should be utilized to promote self-empowerment, skills development, capacity building and lifelong self-learning behaviour across the African continent." [From the abstract]

Suhr-Sytsma, Nathan 'A Secret History of the Nation': Small Magazines at Writivism 2017. https://africainwords.com/2017/10/30/a-secret-history-of-the-nation-small-magazines-atwritivism-2017/ (Posted 30 October 2017) [12/11/17]

How does our sense of cultural and literary history shift, the author asks, "if we start not from celebrity authors or landmark novels but from small magazines and the literary networks they foster?" This question motivated the discussions of a group of academics, editors and writers, who took up the long history of literary production across the African continent as part of the fifth annual Writivism Festival in Kampala, Uganda. This is the second in a new series of articles published in Africa in Words that have come out of conversations and debates between a new interdisciplinary network of researchers and literary producers examining the circulation and production of small magazines in SubSaharan Africa, the AHRC Research Network, 'Small Magazines, Literary Networks and Self-Fashioning in Africa and its Diasporas' ${ }^{*}$. While these conversations are very interesting, there is not perhaps a great deal here about the practical experience of publishing, and the challenges of sustainability of African little magazines, many of which have not survived, either in print or online. However, the author does report about the experience of Igoni Barrett, former Editor of Farafina magazine published by Muhtar Bakare's Kachifo Ltd in Nigeria, which ceased in 2009 (and plans to revive the magazine as a non-profit venture of the Farafina Trust http://farafinatrust.org/programmes/publication-and-circulation-ofmagazine/ have not thus materialized.) Bukare wanted a magazine to be a cross between Vanity Fair and The New Yorker for Nigerians, and it began life online. Bakare and Barrett found, however, that it was extremely difficult to sell the print edition to a general audience in Nigeria. The Harvard and Yale libraries and the like would subscribe to a high quality Nigerian magazine, but Bakare started the magazine in order to foster serious conversations among Nigerians. "What is clear in Nigeria", Barrett is reported as saying, "is that there's a literary renaissance of sorts", but what is less clear is how to cultivate a sustainable market for print.

${ }^{*}$ Note: see http://gtr.rcuk.ac.uk/projects?ref=AH\%2FP006930\%2F1.

Tomaselli, Keyan G. Perverse Incentive-seeking, and the Political Economy of South African Academic Journal Publishing. http://www0.sun.ac.za/scicom/wp-content/uploads/2012/10/Tomaselli-Economy-of-SouthAfrican-Academic-Journal-Publishing-Final.pdf [19/10/17]

Who pays? That is one of the key questions in this provocative presentation that focuses on the research economy at South African universities. The author highlights some contradictions and imbalances in the South African scholarly publishing scene, characterized partly by an under-supply of resources on the one hand and an over-supply of accredited journals on the other, as well as problems regarding the way researchers are incentivised to publish and journals are funded. South African universities can earn substantial rewards from the Department of Higher Education and Training (DoHET) publication incentives, but the author argues that this incentive system is imperfect because of unbalanced resource 
provision in various aspects of the academic publishing value chain. "Unless the journals themselves as the most crucial link in the publication value chain - and not just universities - are to be funded and new entrants wanting accreditation carefully scrutinised, the whole edifice will remain precarious, and continued perverse incentive-seeking will characterize university research economies, performance management criteria and higher degree administration."

Open access publishing and licensing (see also $\rightarrow$ Predatory publishing, $\rightarrow$ Scholarly publishing)

Bosah, Gabriel; Chuma Clement Okeji, and Ebikabowei Emmanuel Baro "Perceptions, Preferences of Scholarly Publishing in Open Access Journals: A Survey of Academic Librarians in Africa." Digital Library Perspectives 33, no. 4 (2017): 378-394.

http://www.emeraldinsight.com/doi/pdfplus/10.1108/DLP-03-2017-0011 [15/01/18]

Based on an extensive questionnaire survey to collect data, this paper examines the various factors librarians consider while selecting Open Access (OA) journals for publication, and identifies the challenges librarians face with OA journal publishing. The study found that academic librarians, while aware of the 'green' and 'gold' routes, were not familiar with the 'diamond' route. The study also revealed that a large number of the academic librarians have published just a single paper in OA journals, or none at all. The reputation of the journal and its impact factor were seen as very important among the influences that inform them of choosing OA. The majority of the respondents agreed that author fees, and lack of stable Internet connectivity in their countries, were the major barriers to publishing in OA journals. The authors offer a number of recommendations that might lead to a better understanding of the issues involved, and might improve author perceptions of and confidence in OA publications.

Butcher, Neil; Lisbeth Levey, and Kirsty van Gogh Elephant in the Room. The Rise of Open Licensing in Early Literacy in Africa.

http://www.ucwia.or.ug/Elephant\%20in\%20the\%20Room\%20PPT.pdf [22/11/17]

A paper presented at the 4th IBBY Africa Region conference, Rethinking Contemporary Literature for Children and Young People in Africa, Kampala, 22-24 August 2017. Digitization and open licensing are disruptive, the authors state in this PowerPoint presentation; and "Africa needs a vibrant indigenous publishing industry for economic, cultural, and educational reasons. Willingness to explore, understand, and experiment with open licensing are required for future sustainability. Don't ignore this elephant."

In this introduction to open licensing, the authors set out the basics of Creative Commons license conditions, describe examples of picture-story books created under Creative Commons licences by publishers in India and in Africa; discuss its likely impact on early childhood publishing in Africa, and provide examples of possible business models (digital, free, print products sold, or for a fee) and review the likely cost implications. They stress the need for new business models that incorporate open licensing. In their summary, the authors say: "Publishers can benefit by engaging with how paradigms are shifting and innovate accordingly. Many new business models depend on donor funding and/or voluntarism. Some show promise: e.g. combine 'content-as-a-service' with other income streams. Diversification may enable specialized teams of early literacy and publishing 
experts to remain sustainable. New business models are in their infancy. [There is] urgent need for action research to find suitable, sustainable new organizational forms."

Chilimo, Wanyenda; Aggrey Adem, Ajwang' Nicholas Walter Otieno, and Mary Maina "Adoption of Open Access Publishing by Academic Researchers in Kenya." Journal of Scholarly Publishing 49, no. 1 (2017): 103-122.

http://utpjournals.press/doi/10.3138/jsp.49.1.103 [18/12/17]

This study investigates Kenyan scholars' adoption of open access (OA). The authors used a questionnaire to collect data from academic researchers at selected Kenyan public universities. The findings of the study indicate that while Kenyan researchers have embraced the concept of OA, challenges such as a lack of mechanisms to guide academic researchers on where to publish, a dearth of funding mechanisms to cover article processing charges, as well as a lack of accreditation mechanisms for regional and national journals are exposing Kenyan academic researchers to unscrupulous journal publishers and predatory publishing outlets. The authors suggest that OA advocates in Kenyan universities need to devise innovative ways of raising awareness about OA, and that these universities should provide the environment, infrastructure, and capacity building needed to support OA.

Gray, Eve GraySouth - A New Version of my Blog. Publishing Development Research in Africa.

http:/graysouth.co.za/2017/04/13/graysouth-a-new-version-of-my-blog-publishingdevelopment-research-in-africa/ (Posted 17 April 2017)

Eve Gray introduces a new version of her always informative and provocative blog, now called GraySouth. Open Access-A View from the South (previously called Gray-Area), that focuses on access to knowledge and open access from the perspective of an emerging economy in Africa, in this case South Africa. "The blog interrogates the global power relations that, through conventional thinking, inhibit our ability to make the most of the knowledge that we generate", she says. And it explores the ways in which new media and new publishing models can contribute to delivering strategic development impact, harnessing the ever-changing potential of online communication. Many of her past posts have dealt, in one way or another, with the issues of the politics of the dominant journal publishing system and the impact of the 'journal fetish' - for the sake of prestige and promotions - on the more complex ambitions of a research system like South Africa.

Levey, Lizbeth An Open Knowledge Primer for OER Africa.

https://www.academia.edu/22972044/An_Open_Knowledge_Primer_for_OER_Africa [05/11/17]

First there were Open Educational Resources (OER) and then there was Open Access (OA). Increasingly academics and researchers are now making Open Data integral to scholarly communication. Rather than segmenting the three, many practitioners use the phrase 'Open Knowledge'. This useful primer and compendium about open access publishing in subSaharan Africa is grouped into three sections: open access publishing, African university repositories and policies, and creating enabling policies for open access publishing. These sections are followed by an appendix with an annotated list of major university repositories in anglophone sub-Saharan Africa. The main section devoted to open access publishing offers a range of information about definitions, current practice, basic facts about open 
access and journals, publisher policies and author rights, the threat to quality posed by shoddy predatory open access publishers, and an open access "to do list".

\section{Nordling, Linda African Scientists Get their Own Open-access Publishing Platform.} https://www.nature.com/news/african-scientists-get-their-own-open-access-publishingplatform-1.23018 (Posted 15 November 2017) [18/12/17]

Reports about a new platform, called AAS Open Research, launched by the African Academy of Sciences (AAS) http://aasciences.ac.ke/ in Nairobi in November 2017, that aims to promote wider visibility of research being conducted on the continent. The pioneering open access publication model (currently limited to researchers within the AAS community) is being created in collaboration with the London-based open-access publisher F1000 https://f1000research.com/, adopting the model of its F1000Research publishing platform. AAS Open Research will publish articles, research protocols, data sets and code, usually within days of submission and before peer review. F1000 staff will arrange post-publication peer review: the reviews and the names of their authors will be published alongside the papers. The papers will be indexed in abstract databases such as PubMed only after they pass review.

Note: for more details see also http://www.universityworldnews.com/article.php?story=20171117095235386 and https://www.aasciences.ac.ke/updates/blogs/aas-open-blog/.

Raju, Reggie; Jill Claassen, and Elizabeth Moll "Researchers Adapting to Open Access Journal Publishing: The Case of the University of Cape Town." South African Journal of Library \& Information Science 82, no. 2 (2016): 34-45.

http://sajlis.journals.ac.za/pub/article/view/1628/1468 [23/10/17]

Reports on the contribution of the openness movement to the changing mode of distributing scholarly literature. The authors argue that the University of Cape Town (UCT), a leading research university on the African continent with relatively high research output, has a social justice obligation to distribute freely its scholarly research to the widest audience possible. Contributing to this social justice obligation through the sharing of research output via open access (OA) platforms are the university's progressive OA policy, and activities to ensure roll-out of the policy, as well as its commitments to support article processing charges (APCs), follow the global trend with regard to OA publishing. The authors, using a case study design, report that these factors have contributed to UCT's researchers adapting to publishing their journal articles on OA platforms. The investigation concludes that, in an era of fiscal constraints, the visibility of research is important to source funding and to meet the institution's social justice obligation; and therefore adapting to new publishing trends is an imperative for UCT researchers.

Raju, Reggie, and Jeremiah Pietersen "Library as Publisher: From an African Lens." The Journal of Electronic Publishing 20, no. 2 (2017)

https:/quod.lib.umich.edu/j/jep/3336451.0020.203?view=text;rgn=main [18/01/18]

Examines the new trend of the (academic) library as a publisher, from an African perspective. 'Library publishing' is a growing area of librarianship and is defined as a set of activities that support the creation, dissemination, and curation of scholarly, creative, and/or educational works. Libraries are using formal production processes to publish original works by scholars, researchers, and students. In the African context, the authors say, these "services must delivered for non-profit purposes and must be intended to advance the 
principles of social justice. The service may support a single element of the publishing process or it may be a comprehensive programme that supports the entire process. Library publishing services are as diverse as libraries would want them to be and may include a variety of media formats and its intended audiences." Given that this is relatively new service, there are many African libraries that are still grappling with the institutional repository stage of publishing, while there is a small but growing number that are offering a more advanced service that includes, inter alia, the publishing of journals and monographs. "Some South African academic institutions, via their libraries, have stepped-up to the plate to make scholarly content freely accessible to both users and authors via a suite of diamond open access services." The authors argue that "the library as a publisher must gain traction quickly as a mainstream service provided by the higher education libraries in South Africa", and that "the benefits for the provision of 'library as publisher' service is colossal for development in the global South."

In their conclusion the authors state: "The need for authors to have their works widely distributed and the need for students to have access to low cost textbooks are among the many layers of the 'open access publishing onion'. At the core of the need for African academic libraries to adopt the role of publisher is the determination to support an African curriculum, a decolonized curriculum that is reflective of African imperatives." Mainstream publishers, the authors claim, "have little or no interest in publishing such works as the markets for these are small with minimal profit or none at all."

Schöpfel, Joachim “Open Access to Scientific Information in Emerging Countries." D-Lib Magazine 23, no. 3/4 (March/April 2017)

http://www.dlib.org/dlib/march17/schopfel/03schopfel.html [18/12/17]

Access to information plays a critical role in supporting development. Up to now, the open access movement has been most successful in the Western hemisphere. However, the demand for open access is great in the developing world as it can contribute to solving problems related to access gaps. Five emerging countries, called BRICS - Brazil, Russia, India, China and South Africa - play a leading role, with a significant influence on regional and global affairs because of their large and fast-growing national economies, their demography and geographic situation. In order to better understand open access in each of the five countries, the author examines current conditions in each country, relying on data provided by information professionals and scientists from BRICS countries, using an empirical approach focused on country-specific characteristics and challenges.

With regard to the situation in South Africa, the author says that South Africa may not have the same global influence as China or Russia, but that it nonetheless plays a significant role on the African continent and in particular in the Sub-Saharan region. "The potential is real, and the opportunities are there. Compared to other countries, the uptake and awareness of open access, however, seems still low; open access is still seen as an experimental option. ... A recent survey on open access and journal cancellations observes that South African open access initiatives are in their early stages of development and that academic librarians have not really embraced such initiatives." 


\section{Predatory publishing}

Beshyah, Salem A. "Predatory Publishing: A Wake-up Call for Editors and Authors in the Middle East and Africa." Ibnosina Journal of Medicine and Biomedical Science 9, no. 5 (2017): 123-125. http://www.ijmbs.org/text.asp?2017/9/5/123/213921 [23/10/17]

This short article/editorial considers the concepts and practices of predatory publishing with a particular focus on the challenges in the Middle East and Africa. The concept and practice of open access scholarly publishing, the author says, is being damaged by the activities of the predatory publishers. Predatory journals charge an article processing fee to authors, yet do not provide the hallmarks of legitimate scholarly publishing such as peer review and editing, language enhancement, and support by credible, experienced editorial boards, physical editorial offices, and other editorial standards. In such sham journals, peer review is either cursory or absent. "Consequently, these journals pose some new ethical issues in journal publishing. This new danger threatens the integrity of scholarly publishing. Internetonly OA publishing is a valid way for researchers to reach the public without a paywall separating them. However, of the thousands of OA scientific journals today, perhaps as many as $25 \%$ are considered fake, existing only to generate income by charging authors high-processing fees."

Mouton, Johann, and Astrid Valentine "The Extent of South African Authored Articles in Predatory Journals." South African Journal of Science 113, no.7/8 (2017): 1-9.

http://www.sajs.co.za/sites/default/files/publications/pdf/SAJS-113-7-

8_Mouton_ResearchArticle.pdf [19/10/17]

Another version also at http://postgradenvironments.com/wpcontent/uploads/2017/10/Mouton-2017-Predatory-publishing-in-South-Africa_Scale-andchallenges_June-2017_SU_J....pdf

A critical examination of so-called predatory publishing in academic circles in South Africa, which confirms that predatory publishing is not only present, but also becoming increasingly common. The study highlights the challenges and dangers that arise from predatory publishing, including how this could compromise the careers of young scholars and scientists, as well as posing a threat to peer review. The authors present a first estimate of the extent of predatory publishing amongst South African academics. This estimate is based on an analysis of all South African authored papers that qualified for subsidy over the period 2005 to 2014. The analysis shows that over 4,000 South African papers were published in 48 journals which the authors re-classified (refining Beall's classification, http://beallslist.weebly.com/) as either being probably or possibly predatory. A breakdown of these papers by year shows that the greatest increase in predatory publishing has occurred since 2011. Results are also presented of the distribution of these papers by individual universities and the scientific field.

In the final analysis, the authors state, "it is clear that predatory publishing poses a serious challenge to science in South Africa. If it continues to increase at the rate of growth seen in the past 5 years, predatory publishing may well become accepted practice in some disciplines and at some universities. Not only will it affect the very fabric of the science system (our confidence in the peer-review system), but it will also undermine the trust and confidence of the general public in science and its products." The authors conclude with some suggestions about predatory publishing and its pervasive consequence for our trust in 
science, and how this should be addressed by the major stakeholders in the South African higher education system.

\section{Opara, Jackie Nigeria's Predator Problem.}

http://www.researchresearch.com/news/article/?articleId=1370873 [18/12/17]

Nigeria represented the third-largest author group in a recent survey of nearly 2,000 papers published in predatory journals, after India and the United States. The survey, published in Nature $^{*}$ in September 2017, finds that the scourge of predatory publishing hits developing and developed country scientists alike. But it admits that little is known about why academics opt for this ill-reputed platform for their work. Jackie Opara examines why so many Nigerian researchers publish in predatory journals and fall prey to the predator's jaws, and suggests some ways to beat the scourge.

*See https://www.nature.com/news/stop-this-waste-of-people-animals-and-money-1.22554

Wild, Sarah Guide: How to Spot Predatory Academic Journals in the Wild. https://africacheck.org/factsheets/guide-how-to-spot-predatory-academic-journals-in-thewild/ (Posted 17 October 2017) [07/11/17]

A recent study published the Centre for Research on Evaluation, Science and Technology (CREST) at Stellenbosch University in South Africa (see paper by Johann Mouton and Astrid Valentine in this section) found that between 2005 and 2014 more than 4,200 South African academic articles were published in 47 journals which were classified as "possibly" or "probably" predatory. These 47 journals qualified for the department of higher education and training's subsidies, meaning that universities and sometimes the researchers themselves received money for publishing in them, and which, the author says, could have cost South Africa up to R300 million in subsidies.

This is a useful factsheet from Africa Check https://africacheck.org/ describing the nature and modus operandi of such predatory journals. Although it is not always easy to identify predatory journals, there are certain red flags that move a journal from "potentially" predatory to "not to be trusted", and the author suggests a number of pertinent questions that ought to be asked before work is placed with such questionable academic journals - that can easily dupe researchers, and seriously erode the body of science and scholarship generally - and "how to avoid such junk from polluting your research."

Publishing in African languages (see also $\rightarrow$ Reading culture and reading promotion)

Note: this sub-section lists books, articles, and other documents that deal with various aspects of publishing in African languages, and marketing and distribution of indigenous language books. Articles that deal exclusively with writing and writing systems in indigenous languages, or issues relating to orthographies, etc., are not included.

Dyssou, Nanda An Interview with Ngũgĩ wa Thiong'o.

https://lareviewofbooks.org/article/an-interview-with-ngugi-wa-thiongo/ (Posted 23 April 2017) [05/05/17]

An extensive and hugely insightful interview in the Los Angeles Review of Books with the world-renowned Kenyan writer, scholar, and social activist. Ngũgĩ wa Thiong'o talks about his role in the writing community, his publishing history and successes, his readership, what he considers to be his most important accomplishments, and his strong views on writing and publishing in African languages. "The problem is that, unfortunately, those that write in 
African languages remain invisible, their works are hardly ever reviewed or translated. Publishing venues are limited" he says, and getting published "is one of the most infuriating challenges of writing in African languages. There are hardly any publishing houses devoted to African languages. So writers in African languages are writing against great odds: no publishing houses, no state support, and with national and international forces aligned against them. Prizes are often given to promote African literature but on the condition that the writers don't write in African languages."

In response to a question where he thinks the future of reading and writing is headed, Ngũgĩ says "the new technologies, electronic media, open vast possibilities. In Globalectics, I have argued that orality is coming back. I call it cyberorality. Look at the language of the Internet: chat rooms, Facebook friends, communities, et cetera. Social media is the electronic version of the old rumour mill writ large. We used to call it bush telegraph - that is, before the Internet. Maybe we should now call it 'electronic rumour.' But for Africa, the real frontier is writing and publishing in African languages."

\section{Mila [Anon.] Angie Motshegka Launches Largest Publication Project for Indigenous} Fiction at SABF.

http://bookslive.co.za/blog/2017/09/08/angie-motshegka-launches-largest-publicationproject-for-indigenous-fiction-at-sabf/ (Posted 08 September 2017) [17/10/17]

Reports that South African Basic Education Minister, Angie Motshekga has launched, what is claimed to be the largest publication project for indigenous language fiction in South Africa's history, at the 2017 South African Book Fair. The initiative, called WritePublishRead http://viaafrika.com/writepublishread/ is the brain child of publisher Via Afrika, working in association with the African Language Association of Southern Africa (ALASA) http://www.alasa.org.za/. It aims to give hitherto unpublished local writers of indigenous language fiction the chance to be published in their home language. According to the report, less than $1 \%$ of books in South African libraries are in indigenous languages, despite the fact that these are the home languages of $76 \%$ of the population. This lack of relevant reading materials "contributes to an astounding $60 \%$ of South Africans living in a home without a single book" the report claims. WritePublishRead is open for any language, and any person. Authors can work through the handbook and/or a free self-publish online course, and publish their material. The WritePublishRead initiative enables authors to self-publish their books as e-books only. The online course does, however, provide them with information on how to print their book themselves, if they so choose.

On their Web pages publisher Via Afrika argues that "we need to start with the remotely located individual in the most rural parts of the country to convince the remaining $86 \%$ of people that reading adds value. In providing reading material and motivation that will entice him or her to read, we can start creating a groundswell that will bring about change. For that to happen we need a reading champion in every community to inspire that community to read. A person is most likely to champion reading when they have a personal stake in what is being read. But the barriers to being published in South Africa are onerously high." 
Möller, Jan, and Beth le Roux "Implementing Constitutional Language Provisions Through the Indigenous Language Publishing Programme." South African Journal of African Languages 37, no. 2 (2017): 203-209.

http://www.tandfonline.com/doi/abs/10.1080/02572117.2017.1378274 [08/12/17]

The trade publishing sector in South Africa produces books primarily in English and Afrikaans, which is not representative of the spread of languages spoken in the country. In particular, there are very few books published for general readers in the local African languages. The Indigenous Language Publishing Programme (ILPP) http://sabookcouncil.co.za/indigenous-languages-publishing-programme/ is a government-sponsored initiative that aims to improve the situation. This article assesses the impact and sustainability of the ILPP as an attempt to represent the official languages more equally in the publishing industry. The study, based on an analysis of documents and interviews, found that the national language and book policies have not been well implemented, which is seen as a failure in terms of reaching constitutional ideals. Moreover, the authors say, despite the ILPP being an attempt at creating language equality, the initiative seems not to be sustainable because it is reliant on external funding. The Department of Arts and Culture (DAC) is not apparently willing to fund such a project on an ongoing basis, which puts the programme's longevity at risk. "As a result, the ILPP's influence remains limited. The minority languages remain under-represented and this raises questions about whether there is in fact a viable market for books in all of the South African languages."

Trok, Lorato The Importance of Reviewing Children's Books in African Languages. A Case for Setswana.

https://www.puku.co.za/en/importance-reviewing-childrens-books-african-languages/ (Posted October 2017) [31/10/17]

In South Africa, for many years children's stories have been published in English and Afrikaans, languages mostly spoken by a minority of the population. Even though the publishing industry has changed over the years, publishing children's stories still remains largely dominated by English and Afrikaans. While there has recently been a surge in the number of authors writing children's stories in African languages, including Setswana, unfortunately children's authors in South Africa are not as celebrated as biographers, political writers, poets and the likes. Not a great deal of publicity and credit is given to these authors, nor the translators. It is also a struggle to secure a publishing deal with commercial publishers for books in African languages, the author says, and therefore writers resort to writing in English as it is easier to get their work published. The Puku Children's Literature Foundation https://www.puku.co.za/en/about/ encourages reviewing of children's books written in African languages, and will be facilitating creative writing workshops across the Northern Cape, a province with a large population of the indigenous San people, a people whose languages are at the risk of extinction and whose stories need to be told: "Reviewing children's books in South and Southern Africa will bring to life stories, identities and cultures of people whose stories are not mainstream, through Puku's writing workshops.... Puku does not only review books, but uses reviewers who are experts in the field of early literacy, education and African languages. ... Reviewing children's books creates a robust environment for all sectors of the book chain in the country." 
Reading culture and reading promotion (see also $\rightarrow$ Children's books publishing, $\rightarrow$ Publishing in African languages)

Association for the Development of Education in Africa (ADEA). Working Group on Books and Learning Materials A Comparative Study on the Role of Digital Media and Print Media in Enhancing Literacy and Reading Culture in Africa. A Study Commissioned by ADEA Working Group on Books and Learning Materials (WGBLM). http://www.adeanet.org/en/system/files/resources/report_of_print_vs_digital_study.pdf [24/06/17]

A report commissioned by ADEA's Working Group on Books and Learning Materials http://www.adeanet.org/en/working-groups/books-and-learning-materials to examine the general context of literacy and reading culture in Africa, focusing on the contribution of printed books and digital materials. It explores the challenges of digital media and suggests interventions "that optimize reading of printed books and digital content to improve literacy for a better reading culture in Africa both in international and national languages." The research draws attention to the fact that, as the number of printed books is expanding to reach a variety of audiences - covering a wide range of topics and knowledge - electronic publishing is equally expanding rapidly. "The two options are now available to publishers and the choice of a publisher will depend on a number of factors such as the cost, objectives and the prevailing circumstances." The study notes that "numerous reports indicate that many pupils and students go through primary and secondary school without acquiring sufficient reading skills." It recommends that "since technology will not replace reading in the near future, it is imperative to use the technology to enhance it. Reading on paper will always remain important and enjoyable and this means that the printed book will never lose its value and importance."

\section{Matsinde, Tapiwa Challenging the Statement that Africans Don't Read.}

http://www.shokopress.com/challenging-the-statement-that-africans-dont-read/ (Posted 02 March 2017) [15/05/17]

A spirited rebuttal to the persistent refrain that 'Africans don't read', by Tapiwa Matsinde of Shoko Press http://www.shokopress.com/, an independent publisher of illustrated African art books: "Applying the blanket statement that 'Africans Don't Read', commenting on it and then leaving it at that is not going to help address the situation. And having stated the problem we need to understand why this is so and then work together with all who have a stake to find the appropriate solutions." A reading culture is not alien to Africa, the author says, "much has been said of the continent's rich oral traditions passed down through the generations, but as Saki Mafundikwa's insightful book, Afrikan Alphabets* can attest written traditions existed in Africa for centuries. ... So given this foundation and heritage what went wrong? One reason is that over time many written traditions fell victim to the destructive practices of all-conquering wars, infighting, and colonialism all intent on wiping out what had gone before in a bid to establish the ways of the conquerors and cement their authority." Matsinde acknowledges that recent statistics and research show low levels of reading for pleasure and low volumes of book sales across most of the continent when compared to the developed world. One of the main reasons for low reader numbers across the rest of Africa points towards the expense of buying books, she says, which for a majority can cost more than several months wages, especially if imported, which adds to the costs when local taxes are added. And in some countries book piracy is a serious threat preventing publishers from 
publishing more books, and authors from earning a living from their work. "But putting costs aside for a moment and looking at other factors we feel another reason for a lack of interest can be attributed to the types of reading material available and that the question we should be asking is 'What do Africans want to read?' ... Looking to today and publishing books with regards to Africa maybe it has been the lack of relevant books that African audiences want to read, or the availability of accessible formats that have had an effect. ... In recent years modern African literature has commanded greater global attention bringing forth famous African authors like Chimamanda Ngozi Adichie and Taye Selasi, to name but two, who are creating modern heroes and heroines that African readers can on some level identify with, and stirring interest among an African readership. And their success, coupled with the relative ease and affordability of online publishing, has led to more self-published authors writing the kinds of stories that reflect the realities, hopes, dreams and desires of a modern African readership."

However, to keep this momentum going there is a need to invest in African readership, "and for a more conscious effort to make relevant reading material available; but publishing has traditionally been an expensive and risky business with a high barrier to entry. This creates a sort of catch-22 if you like. Whilst there undoubtedly need to be more books that appeal to a diverse African readership, at the same there also need to be willing buyers to help maintain a viable publishing and book selling industry. It will take a concerted effort and more crucially targeted investment and support by government, public and private sector organisations, into libraries and providing incentives for writers, publishers and booksellers of local literature. But we are not naive enough to think that things can change overnight."

*Note: Saki Mafundikwa Afrikan Alphabets: The Story of Writing in Africa. New York: Mark Batty Publisher, 2004. Second (paperback) edition 2007. http://www.markbattypublisher.com/ (not currently in print?)

Mugambi, Florence "Exploring Reading Habits and Academic Success in Rural Kenya." IFLA Journal 41, no. 4 (2015): 353-363.

http://journals.sagepub.com/doi/abs/10.1177/0340035215610303 [12/04/17]

Explores the relationship between reading habits and reading materials, and academic success of primary school students in the Ontulili community of Kenya. The study revealed high levels of satisfaction among the participants with respect to their perceived reading abilities, educational performance, and overall preparedness for further education. However, the data gathered also pointed to a severe scarcity of learning materials, low reading skills, poor infrastructure, below average educational performance, and low preparedness for further education. The author concludes that lack of exposure to relevant reading materials, educational resources, as well as opportunities "leads to subtle contentment alongside individual inability to excel as manifested by low test scores in the national examinations." In order to realize academic success in the study area and among other comparable communities, well-designed interventions such as promotion of reading across the school curriculum, and establishment of fully equipped libraries, consistent with the rigors of modern academic demands, must be created. 
Rule, Peter, and Sandra Land "Finding the Plot in South African Reading Education." Reading \& Writing - Journal of the Reading Association of South Africa 8, no 1 (2017): 8 pp.

http://www.rw.org.za/index.php/rw/article/view/121 [19/01/18]

Also at

https://www.researchgate.net/publication/319323408_Finding_the_plot_in_South_African _reading_education

The dire state of South African reading performance, indicated by consistently low rankings in both national and international studies, "shows that we have lost the plot in the teaching of reading", the authors argue. "To find it, we need to move beyond the predominant mode of reading as oral performance, where the emphasis is on accuracy and pronunciation, to reading as comprehension of meaning in text. While reading research in South Africa has been conducted mainly in school contexts, this case study is of a school and Adult Basic Education and Training Centre in a rural KwaZulu-Natal community near Pietermaritzburg." The study found that an oratorical approach to reading dominated in both settings, and it suggests that developing the way in which teachers understand the teaching of reading, and transforming the teaching practices of those who teach as they were taught in the education system of the apartheid era, are key to improving the teaching of reading.

Note: For a shorter summary version see also

Rule, Peter South Africa Has a Reading Crisis: Why, and What Can be Done About it.

https://theconversation.com/south-africa-has-a-reading-crisis-why-and-what-can-be-done-about-it-88711

(Posted 8 December 2017) [19/01/18]

Siboto, Charles 'Stories are in our DNA' - Local Publisher, Charles Siboto, on South Africa's Reading Culture.

http://bookslive.co.za/blog/2017/09/29/stories-are-in-our-dna-local-publisher-charlessiboto-on-south-africas-reading-culture/ (Posted 29 September2017) [06/11/17]

Charles Siboto, until recently an editor of children books and youth literature at NB Publishers, writes about South Africa's reading culture, competing with international titles, and reading as tool to raise standards of education. The South African publishing scene, he says, "is a fine balancing act of publishers trying to make books as accessible as possible while making enough money to continue existing so as to publish more books. ... The problem with publishing in English is that people still buy more international titles than local ones in English. ... Competing with international publishers is difficult because as a country we are not yet confident enough in the power of our own stories and this should not be so. South African publishers publish books of a high calibre that can compete with titles from the UK or the US, but they get lost in the crowd." It is also vital to promote children reading in their mother tongues. However, "this is way easier said than done because the resources are scarce. Resources aside, many black households are afraid to focus on children reading in their mother tongue because they might then miss out on learning English. This is not so, children who can read their own language well can better transition into a second language and excel at it. Being a multilingual society is complex, but we gain more when we allow people to read in their own language and learn English in addition." 
South African Book Development Council National Survey into the Reading and Book Reading Behaviour of Adult South Africans 2016. Sanlamhof, South Africa: South African Book Development Council, n.d. [2017?]. 104 pp.

http://sabookcouncil.co.za/wp-content/uploads/Final-Report-NRS-2016.pdf [17/06/17]

A meticulously detailed study - supported by extensive use of charts and demographics that was commissioned and managed by the South African Book Development Council http://sabookcouncil.co.za/ as part of the Growth and Development Strategy for the South African book sector. An introduction sets out the context, describes the study methodology and approach, and stresses why reading is critical to fulfilling individual potential and collective social development. Subsequent chapters examine the role of reading in the South African leisure activity landscape, perceptions about books and reading among various age groups and demographics, book reading attitudes and behaviour, use of libraries and library borrowing patterns, reading initiatives and programmes and their awareness by the public, and more. A concluding Growth Summary provides growth insights about reading and reading habits in the country (including reading in indigenous languages), and makes a number of recommendations how to create a lively reading culture and encourage growth in this area.

Scholarly publishing (General) (see also $\rightarrow$ Journals and magazine publishing, $\rightarrow$ Open access publishing and licensing, $\rightarrow$ Predatory publishing)

Ayitey, Wisdom Kwesi "Scholarly Publishing: The Missing Link in MUCG's Strategic

Plan (2006-2011)." Globus: Interdisciplinary Journal of Methodist University College Ghana 3, no.

1 (2015): 92-107.

http://www.iiste.org/Journals/index.php/GLOBUS/article/view/22970/23507 [16/12/17]

Critically examines the scholarly publishing landscape at Methodist University College Ghana (MUCG), a private university. During its first ten years of existence MUCG has engaged in a variety of scholarly publishing, but only slow progress has been made; very limited visibility has been generated for academic publishing output at the College, and promotion and marketing activities have been negligible or non-existent. This paper seeks to investigate the reasons for these failures, which include the lack of a scholarly publishing policy and the absence of a strategic plan, weak editorial boards, an inadequate peer review process, distribution problems, and no marketing plans for either journals or books published. The author makes a number of recommendations how these issues and challenges could be addressed.

Eyiolorunshe, Toluwani A.; Foluke O. Okocha, and Sunday A. Oguntayo "Perception of Lecturers on the Quality of Scholarly Publications and the Challenges Facing Scholarly Publishing in Nigeria." The Information Technologist 14, no. 1 (2017): 80-89.

https://www.ajol.info/index.php/ict/article/view/159934 [15/10/17] Using a descriptive survey method, this study examines the perception of lecturers of the quality of scholarly publications, and the challenges of scholarly publishing in Nigeria. The study population was comprised of academic staff at Ibadan University, Nigeria. Five out of nine faculties (as at August 2012) were selected using a simple random technique. The findings of the study show, the authors state, "that lecturers in the University of Ibadan attested to the quality of scholarly publications in Nigeria", but "lack of funds and general 
incentives to aid scholarly publishing were identified as challenges to scholarly publishing in Nigeria."

Kitchen, Stephanie The Academic Book in the South: Conference Report (7-8 March 2016,

British Library)

https://ucldigitalpress.co.uk/BOOC/Article/1/23/ [29/06/17]

Video recordings: (of presentations dealing with African book and journal publishing):

Walter Bgoya Panel: Academic Publishing in the South.

https://ucldigitalpress.co.uk/BOOC/Article/1/40/

Akoss Ofori-Mensah Academic Publishing in the South: The Ghanaian Experience.

https://ucldigitalpress.co.uk/BOOC/Article/1/27/

Stephanie Kitchen et al Academic Authorship and Knowledge Production.

https://ucldigitalpress.co.uk/BOOC/Article/1/29/

Other:

Storyfy (Tweets)

https://ucldigitalpress.co.uk/BOOC/Article/1/26/

Final Panel Discussion \& Concluding Comments

https://ucldigitalpress.co.uk/BOOC/Article/1/33/

This two-day conference was organised by the British Library in association with The Academic Book of the Future project https://academicbookfuture.org/. This is the conference report $^{1}$ and includes succinct summaries of papers presented by plenary speakers, including a small number from Africa that offer interesting insights.

Tanzanian publisher Walter Bgoya provides some reflections based on 44 years in African publishing. He stated that African publishing is best understood as a series of contradictions which begin in the quality of education: students' poor performance, a weak book culture, and the weak foundation of primary and secondary education, now going back three or four generations. School leavers are not prepared for work and publishing is starved of competent staff. Then there are the problems facing the African university. The shortage of books may not be the most critical problem here, but it is important. A major issue is the high prices of imported books from the UK and the US. Cheaper Indian editions are widely sold in Africa, costing less than half of US/UK editions, although prices are going up. However, students still prefer Western books. African publishers need to acquire rights to publish local editions. Bookshops should get more substantial discounts. In African universities, focus needs to be placed on developing common curricula and harmonising course book requirements. The fastest way for universities to get books would be for their university academics to write them. African publishers are now penetrating Northern markets, however getting US and UK academics to publish in Africa remains problematic. In the US, lecturers do not get tenure if they publish in Africa; in the UK, the choice of publisher is determined by matters of prestige and citations. Such initiatives demand economic viability for African publishing. The market is small but private universities are growing rapidly. This explosion of the student population provides a challenge to both the African and the Northern publisher - but may act as a disincentive to licenced editions. Piracy is another serious impediment. Moreover, "we need to seek how to exploit copyright practice to benefit African publishing", Bgoya stated. Copyright evokes a gamut of issues: "As a publisher, respect for copyright protects the business. But there are also questions of access and the democratisation of knowledge." 
Akoss Ofori-Mensah from Sub-Saharan Publishers in Ghana was another speaker. Her company has published several academic books for the universities in Ghana, albeit with mixed success in terms of sales, while in Africa generally there is a lack of proper distribution channels, libraries are cash-strapped, and good bookshops are few and far between.

Mary Jay, former CEO of African Books Collective Limited (ABC) http://www.africanbookscollective.com/, spoke about the activities of this international distribution and marketing organization (currently serving 155 publishers from 24 African countries), and about the many challenges facing publishers in Africa. The new digital environment has significantly changed African Books Collective's methodology - through ebooks, print on demand, e-platforms for libraries, and open access. But she also stated that "there isn't one digital panacea for the whole of Africa"; rather there would be utilisation of different routes. She provided some facts and figures about $A B C$, which handles 3,000 titles, of which $63 \%$ are academic books. This mirrors the figure of academic sales to the US, while sales in the UK and the rest of Europe are regrettably low. Twenty per cent go to the 'Rest of the World' category and $20 \%$ to Africa. The latter are generally comprised of donor-funded orders and 'real' sales to South African libraries. Intra-African trade is almost non-existent. E-book sales are still negligible. E-platforms however, notably Project Muse, have been productive.

Other impediments to progress are corruption in textbook tenders, overseas book donation programmes, and lack of co-publishing. US and UK academic regimes of tenure don't help. The non-inclusion of African-published titles in European and US university courses is notable. On local and global access, African Books Collective reported e-book sales of about $80 \%$ to the US, $6 \%$ to Europe, $5.5 \%$ to Africa, and $8 \%$ to Asia. Downloads are mainly in the US, but Canada, Australia, Kenya, South Africa as well as few countries in Europe all show e-book usage. Expanding access in Africa is about libraries having the resources and digital training, about finance and technical capacity, and understanding in the institutions. Overall, there is no evidence that sales on e-platforms have depressed sales of print books; print book sales have in fact gone up.

On future prospects, Jay feels that access to training in the use of online resources is important. On open access, conventional wisdom is that it needs institutional funding, as the publisher is also taking a risk. More broadly, issues that remain include lack of intra-African book trade, the paucity of library budgets, and heavy dependence on Northern book donations, illustrated by a recent study ${ }^{2}$ showing that only small minority of the donations are recipient request-led. Such donated books are rarely in local languages. If libraries become dependent on donations, this negatively impacts on African publishers. African Books Collective's Intra-Africa Book Support Scheme, no longer funded (due to a change in aid priorities), was hugely beneficial to libraries in Africa, and also to the publishers, as it enabled them to distribute books in local domestic markets.

Notes:

${ }^{1}$ For more about this conference, see also Publishing \& the Book in Africa: A Literature Review for 2016, p. 67. https://www.academia.edu/31441110/Publishing_and_the_Book_in_Africa_A_Literature_Review_for_2016 2 See "Book Donation Programmes for Africa: Time for a Reappraisal? Two Perspectives." African Research \& Documentation. Journal of SCOLMA - the UK Libraries and Archives Group on Africa no. 127 (2015) [Published 2017]: 3-130 (part I), 131-220 (part II). 
Pre-print online versions (freely accessible):

Part I: Book Donation Programmes in English-speaking Africa, by Hans M. Zell

https://www.academia.edu/13165497/Book_Donation_Programmes_for_Africa_Time_for_a_Reappraisal_Part_ I

Part II: Le don de livre, mais à quel prix, et en échange de quoi? Un regard sur le don de livre en Afrique francophone, by Raphaël Thierry (in French, with an abstract in English)

https://www.academia.edu/13166294/Le_don_de_livre_mais_\%C3\%A0_quel_prix_et_en_\%C3\%A9change_de_ quoi_Book_donation_programmes_for_Africa_part_2

Kitchen, Stephanie Interview with Francois van Schalkwyk, African Minds. http://www.readafricanbooks.com/opinions/interview-with-francois-van-schalkwykafrican-minds (Posted 19 September 2017) [15/10/17]

Francois van Schalkwyk heads the South African open access, not-for-profit publisher African Minds http://www.africanminds.co.za/, and he is also the co-author of an important new study The African University Press https://www.academia.edu/33799890/The_African_University_Press (see also separate entry in this section). In this interview with Stephanie Kitchen of the International African Institute he sets out the background to this project, describes the case studies of a number of African university presses that formed part of the report, as well as the publishing practices of academics at these institutions. He also talks about the barriers to achieving a higher rate of open access publishing on the continent, and the steps that are needed to address these: "The expectation of universities for their presses to be profitable in nascent markets, and not giving consideration to the reputational benefits that a non-market-oriented publishing model could yield, is certainly one such barrier." Another is academic authors' expectations of receiving royalty payments from the sale of their books, and university presses in Africa "cannot reconcile open access and the perceived loss of sales income with the royalty expectations of their authors", he says. "Beyond these specific barriers, and I am sure there are others, I think there is a general lack of understanding and confidence to experiment when it comes to open access publishing."

On the topic of institutional repositories Van Schalkwyk states "My concern is that repositories are being seen as a silver bullet when in reality they are part of a broader publishing ecosystem; an ecosystem that consists of institutional repositories, libraries, academic authors, indexing agencies, publishers (both university presses and others), and service providers. I think there are many repositories gathering dust because they were seen as a panacea to making a university's research output more visible and accessible." In their findings and conclusion in the African University Press study the authors asserted that, generally speaking, funding is not the main problem facing African university presses, and that there are other problems, such as outdated employment models, procurement systems, a weak research culture, and inappropriate institutional frameworks that are too bureaucratic. Questioned about the resources issue he responds "yes, resources are an issue. But probably not a uniquely African issue. How many university presses outside of Africa wouldn't want to be better endowed? ... Resources are not the only issue. There is a lack of imagination, of innovative thinking about how to use what limited resources are available. ... University presses and other scholarly book publishers in Africa would benefit from being more connected. Exchanging ideas, sharing challenges, mutually formulating solutions to common problems - these could all contribute to a more confident and dynamic scholarly publishing community across Africa." 
Malapela, Thembani "Access to Scholarly Research Information in Sub-Saharan Africa: A Review." Libri. International Journal of Libraries and Information Studies 67, no. 1 (March 2017): $1-14$.

https://www.degruyter.com/view/j/libr.2017.67.issue-1/libri-2016-0060/libri-2016-0060.xml [23/10/17]

In order to fully contribute to the global knowledge economy, African scholars need access to both global information resources as well as locally published scholarship. However, only a few studies have focused on the African knowledge production vis-à-vis access to scholarly research information in Africa. "This paper examines access to scholarly research information in sub-Saharan Africa. The review focuses on available published works on access to scientific literature in Africa and seeks to understand Africa's scholarly publishing scene. In the process, challenges and opportunities regarding access to scholarly research information are explored. Three approaches in addressing these issues emerge in literature namely (i) open access, (ii) donor-funded schemes and (iii) negotiated access schemes for scholarly content." The author argues that "these approaches have leveraged information access to the African researchers who now have almost the same levels of access to scientific literature as their peers in the developed world." However, African governments, institutions, researchers and librarians still need to exploit the potential of open access, and there remain infrastructural issues challenges that need to be addressed.

\section{Mouton, J. Scholarly Publishing in SA: The Qualitative Imperative.}

http://www0.sun.ac.za/scicom/wp-content/uploads/2012/10/Mouton-Scholarly-publishingin-SA-The-qualitative-imperative.pdf [19/10/17]

Johann Mouton, who is director at The Centre for Research on Evaluation, Science and Technology (CREST) http://www0.sun.ac.za/crest/ at Stellenbosch University, reflects on the growth in scholarly publishing in South Africa over the last 25 years, and how this has been influenced by the subsidy system of South Africa's Department of Higher Education and Training (DoHET). In his presentation, focusing on the "qualitative challenge", he acknowledges that concerns over the quality of scientific outputs and unethical publishing practices have emerged and increased. He gives several reasons for concern over the journals where South African academics publish most frequently, including the persistence of questionable publication practices and predatory journals. However, while agreeing that there are problems that could and should be addressed, the author feels strongly that it would be irresponsible to consider a total scrapping of the scientific publishing system in South Africa, since the funding from this system is a lifeline for science in South Africa.

Mouton says "it is important to emphasize that the digitization of publishing and the advent of OA journals and books are in and by themselves progressive forces. These 'movements' have greatly increased access to knowledge, improved participation in and even the democratization of publishing through more transparent peer-review processes. However, as is often the case, they also contain(ed) in themselves the potential for misuse and abuse by unscrupulous publishers, editors and other actors who are intent only on profiting from these through whatever means of deception and misrepresentation." 
Onyancha, Omwoyo Bosire "Altmetrics of South African Journals: Implications for Scholarly Impact of South African Research." Publishing Research Quarterly 33, no.1 (March 2017): 71-91.

https:/link.springer.com/article/10.1007/s12109-016-9485-0 [15/05/17]

The purpose of this study was to investigate and compare the social media impact of 273 South African post-secondary education accredited journals, which are recognised by the Department of Higher Education and Training of South Africa for purposes of financial support. The author used multiple sources to extract data for the study, namely, Altmetric.com, Google Scholar (GS), Scopus (through SCImago), and the Thomson Reuters (TR) Journal Citation Reports (JCR). Data was analysed to determine South African journals' presence in and impact on social media as well as to contrast social visibility and impact with the citation impact in GS, JCR and Scopus. The results revealed that 2,923 articles published in 122 of the 273 South African journals received at least one mention in social media, and the most commonly used platforms were Twitter and Facebook. The journals indexed in the TR's citation indexes and Scopus performed much better, in terms of their average altmetrics, than non-TR and non-Scopus indexed journals; and there were weak to moderate relationships among different types of altmetrics and citation-based measures, thereby implying different kinds of journal impacts on SM when compared to the scholarly impact reflected in citation databases. In his conclusion the author states that South African journals' impact on social media, just as is the case with countries with similar economies, is minimal but has shown signs of growth.

Onyancha, Omwoyo Bosire "Open Research Data in Sub-Saharan Africa: A Bibliometric Study Using the Data Citation Index." Publishing Research Quarterly 32, no.3 (September 2016): 227-246.

\section{https://link.springer.com/article/10.1007/s12109-016-9463-6 [15/05/17]}

Explores and documents the status of research data sharing among researchers in subSaharan Africa (SSA) and internationally. Relevant data was extracted from the Data Citation Index (DCI) using an advanced search strategy, which was limited to the publication years between 2009 and 2014. Data was analysed to obtain the number of data records by country, institution, subject category, year of publication, and document type as well as the number of citations. The author's findings indicate that only 20 (out of 50) countries in sub-Saharan Africa produced at least one data record in the DCI, with South Africa leading the pack with 539 (61.39\%) records followed by Kenya, Cameroon and Ghana. SSA contributes a mere $0.03 \%$ of the world's research data as compared to $1.4 \%$ of the world's research articles. Research institutions and universities are the major contributors of research data, which largely focuses on genetics and heredity $(61.3 \%)$, biochemistry and molecular biology $(61.3 \%)$, agriculture $(29.2 \%)$ and forestry $(27.3 \%)$. The author states that, citation-wise, the research data has attracted fewer average citations than the articles, and that a correlational analysis of the data reveals that there is a significant correlation between the publication of data and research articles.

University World News Special Reports "African Scholarly Publishing - Network Aims to Strengthen African Scholarly Publishing." University World News 22 September 2017 Issue no. 475

http://www.universityworldnews.com/specialreports/index.php?action=view\&report=134 (Posted 16 October 2017) [23/10/17] 
Reports about a meeting hosted by Witwatersrand University Press, held in Johannesburg on 30 August 2017, that brought together a number of African scholarly publishers to discuss a wide-ranging study undertaken by François van Schalkwyk and Thierry Luescher entitled the The African University Press https://zenodo.org/record/889744\#.Wcdyr7J96pp (the database that is part of this project can be found at http://code4sa.org/african-universitypresses/\#all). One of the report's recommendations was to set up a network of university presses, as well as other scholarly publishers, to be called African Monograph Publishers Network/AMPNet, intended as a network for collaboration, experience-sharing, and advocacy. This UWN Special Report includes a general round-up of the meeting, accompanied by a series of articles and commentary contributed by some of the participants, as follows:

\section{MacGregor, Karen Network Aims to Strengthen African Scholarly Publishing.} [Introduction/Round-up] [23/10/17]

http://www.universityworldnews.com/article.php?story=20170921154031974 [23/10/17]

A small group of African scholarly publishers has launched a network for collaboration, experience-sharing and advocacy - and they have invited other publishers of scholarly monographs across Africa to join. Work has already begun on initial projects including building a shared database of peer reviewers and developing peer review standards. One of the participants at the meeting, Dr Divine Fuh, head of the publications and dissemination programme at CODESRIA http://www.codesria.org/ in Dakar, was reported as saying such a network could also be useful in terms of scholarly book distribution and dissemination, similarly as African Books Collective does outside Africa. Fuh also said CODESRIA was planning a conference in 2018 on 'Rethinking Publishing.' "It is important to invest in research into publishing, not just technical activities. ... We need more publications on publishing - we spend so much time publishing about everything else."

\section{Cox, Justin ABC - Taking African Scholarly Books to the World.}

http://www.universityworldnews.com/article.php?story=20170919142042644 [23/10/17]

African-published books are now as easily available as any book published anywhere and the international market for African scholarship is healthy. However, while African books are now much more easily available outside Africa than they are within; access to these books, and in turn African scholarship, is actually deteriorating. Through the African Books Collective (ABC) http://www.africanbookscollective.com/, African publishers worked together to successfully sell their books to the North - now they must seek operate in the same way in Africa. The article describes the history and development of the not-for profit $\mathrm{ABC}$, its strategies in a rapidly changing publishing environment, its move to a largely digital platform, and the many challenges it - and its participating African publishers - face in the market place.

\section{Klipp, Veronica The Costs of Losing Local Research to Global Publishers.}

http://www.universityworldnews.com/article.php?story=20170920151825375 [23/10/17] Another version also at http://witspress.bookslive.co.za/blog/2017/09/28/wits-universitypress-publisher-veronica-klipp-on-the-costs-of-losing-local-research-to-globalpublishers/ [23/10/17] 
The overwhelming proportion of South African research is placed largely with international publishers, and the academy in Africa in turn is forced to buy back its own knowledge, often at exorbitant prices. As Africa's research output grows, university presses will have to radically improve capacity to have any chance of controlling research outputs in the global knowledge economy. The presses "need to demonstrate their ability to disseminate and create impact in the global knowledge economy. In this way they can contribute to the prestige of the local academy, which must have been a key reason for establishing the first university press in the early 20th century."

Luescher, Thierry, and François van Schalkwyk Universities Need Imaginative, ICTenhanced Presses.

http://www.universityworldnews.com/article.php?story=20170919095942307 [23/10/17] How are African university presses faring under the current 'market' conditions and the contradictory developments of 'robber capitalism' and hyper-marketisation on the one hand, and the emergence of 'social capitalism' and open access knowledge sharing on the other hand? What do African university presses make of the challenges and opportunities presented in the scholarly publishing realm within their contexts? Are they deploying the technological changes in production, distribution and marketing made possible by digitisation and network effects of the internet? Have they adjusted their production processes, gone digital, and bought into the latest technologies to be able to produce ebooks, enhance their visibility and marketing strategies by including social media, and drastically reduce print-runs? Based on a baseline survey of university presses in Africa, in-depth case studies of selected university presses, and an analysis of the publishing choices made by African academics, the authors of The African University Press study https://zenodo.org/record/889744\#.Wcdyr7J96pp examined the opportunities and constraints faced by university presses in Africa. It includes a set of recommendations to university presses and their host institutions as well as to funders interested in supporting scholarly publishing in Africa.

MacGregor, Karen Research Offers Ways Forward for University Presses. http://www.universityworldnews.com/article.php?story=2017092408065766 [23/10/17] Research undertaken to provide an empirically-based overview of African university presses reveals a bleak landscape, but also a group of active presses that are deploying technology to reduce production costs, enhance visibility and widen their reach. It offers ways forward for universities and presses keen to respond to the remarkable growth of research in Africa.

Nyamnjoh, Francis, and Kathryn Toure Desire for Knowledge - Langaa and Publishing in Africa.

http://www.universityworldnews.com/article.php?story=20170919101008762 [23/10/17]

Can enhanced circulation of African worldviews help shape the evolution of humanity?

This is the vision at the not-for-profit Langaa Research and Publishing Common Initiative Group in Cameroon which, along with other African publishers, "seeks to stir the imagination and contributes to cultural development and renaissance." The Group has thus far published more than 500 books in a diverse range of topics and genres. "One of Langaa's most important challenges is making its publications more available in Africa 
where, ironically, African canons and concepts have been repressed and are languishing in hiding and neglect, and textbook publishers predominate."

Zell, Hans The African University Press - A Gloomy Picture. [Commentary] http://www.universityworldnews.com/article.php?story=20170922175606239 [23/10/17] Another version (with Appendix added, "Pan-African and regional book professional organizations, groups, and networks in sub-Saharan Africa: An inventory") also at https://www.academia.edu/34690740/The_African_University_Press_-

\section{_A_Gloomy_Picture}

While the university press is a non-commercial enterprise, it must be run with strictly commercial and business-like efficiency. Evidence from many dormant African university presses - their frequently low profile and visibility, and meagre publishing output paints a gloomy picture and suggests this is not always the case. This is a slightly edited version of a commentary/discussion document submitted to the African Minds The African University Press meeting, with an appendix added, "Pan-African and regional book professional organizations, groups, and networks in sub-Saharan Africa: An inventory".

Note: see also van Schalkwyk, François, and Thierry M. Luescher The African University Press in this section, below.

van Schalkwyk, François, and Thierry M. Luescher The African University Press. Cape Town: African Minds, 2017. 62 pp.

https://www.academia.edu/33799890/The_African_University_Press [05/09/17]

Funded by the Carnegie Corporation of New York, this an impressive new study providing an overview of the current African university press landscape, and examining the opportunities and constraints faced by university presses in Africa. While there are new and enabling conditions and opportunities for university presses to increase production and to widen distribution, the authors ask: How can African university presses make the most of these opportunities? Most likely, they believe, in deploying the technological changes in production, distribution and marketing made possible by digitisation and network effects of the Internet. The study is based on a baseline survey of university presses in Africa, in-depth case studies of selected university presses, and an analysis of the publishing choices made by African academics.

The authors found that "university presses in Africa are not yet making use of technological advances to reconfigure their production, distribution and marketing processes, nor are they experimenting with new publishing models such as open access. While case studies of selected university presses surfaced unsurprising challenges (such as scarce resources and limited capacity), they also show that university presses in Africa are constrained by institutional logics that are holding them back from experimenting with new ways of doing things." The authors' research also revealed that an alarmingly high number of academic authors at one flagship research university in Africa are choosing to publish monographs with predatory publishers. The report concludes with a set of pragmatic recommendations: "recommendations that are simultaneously attuned to the opportunities and to the realities of African university presses as revealed by the research conducted."

Notes: Another presentation of The African University Press project can be found at http://www0.sun.ac.za/scicom/wp-content/uploads/2012/10/Van-Schalkwyk-African-University-Presses.pdf. 
As part of this project, African Minds have also created an interactive map of university presses in Africa that is continuously being updated. Users can either view the map by applying any of a number of filters, or download the full dataset at

https://docs.google.com/spreadsheets/d/1URiTsMVkeM12D1ZT7IfxqcYgVEt0hohIi4xIy983FI8/edit\#gid=0.

Veldsman, Susan Raising the Bar in Scholarly Publishing. The Role of the Academy of Science of South Africa.

http://www0.sun.ac.za/scicom/wp-content/uploads/2012/10/Veldsman-Raising-the-bar-inscholarly-publishing.pdf [19/10/17]

A PowerPoint presentation that provides an overview of several strategic studies on scholarly publishing commissioned by the Academy of Science of South Africa (ASSAf) https://www.assaf.org.za/ in recent years, including its 2006 Report on a Strategic Approach Strategic Approach to Research Publishing in South Africa. ${ }^{*}$ The author elaborates on how the implementation of recommendations from these reports have impacted on scholarly journals and books in South Africa.

${ }^{*}$ Note: freely accessible at http://www.assaf.co.za/wp-

content/uploads/reports/evidence_based/assaf_strategic_research_publishing.pdf

\section{Women in African publishing/Publishing by and for women}

Abrams, Dennis South Africa's Feminist Press Modjaji Books Turns 10: 'Needs and Issues'.

https://publishingperspectives.com/2017/05/colleen-higgs-modjaji-south-africaanniversary/ (Posted 26 May 2017) [24/06/17]

The independent feminist publishing house Modjaji Books in Cape Town http://www.modjajibooks.co.za/ celebrated its 10th anniversary in 2017. Its list includes writing by Southern African women, including fiction, poetry, and biography. This is an interview with its founder, Colleen Higgs, who says the launch of Modjaji a decade ago answered a series of needs and issues: "Modjaji fills a gap by providing an outlet for writing by women that takes itself and its readers seriously. For a small press, Modjaji Books is visible and vibrant and has offered a good platform for the writers we've published." There have been many small moments of joy, she says, but also many challenges, and constant worries about money and cash flow. The book market in South Africa is small, as are the margins, and several bookstores have been forced to close down. There are only a handful of South African writers who can make a living as a writer. "This is very frustrating for authors, and sometimes they take their frustrations out on us, their publishers." On the positive side, there have been some notable rights sales and translations with publishers in other countries. Higgs says "the self- esteem and sense of self-worth that our authors gain from being published fills my heart and makes me proud and happy."

Bookwitty In Conversation with Nigerian Independent Publisher Cassava Republic. https://www.bookwitty.com/text/in-conversation-with-nigerianindependent/5887871f50cef72305af248d (Posted 15 February 2017) [27/02/17] Bookwitty South African Modjaji Books on the Work of Finding Female Voices. https://www.bookwitty.com/text/south-african-modjaji-books-on-the-work-offinding/5885d66c50cef72305aef42d (Posted 15 February 2017) [27/02/17] Bookwitty https://www.bookwitty.com is a new platform "where people can discover, create and share content about books or a variety of topics." It has recently published the 
first two in a series of interviews with African publishers, "part of an ongoing Bookwitty project that celebrates the importance of independent publishers." The interviews cover questions such as 'What is your editorial line?, 'What makes you stand out?', 'What is the most rewarding aspect of being an independent publisher?', to questions about the most significant challenges, how do these publishers interact with their readers, and more.

\section{BOOK INDUSTRY TRAINING/SELF-PUBLISHING}

\section{Publishing education/Training manuals and resources}

Dawson, Colleen Where to Study Publishing in South Africa.

https://www.myebook.co.za/where-to-study-publishing-in-south-africa (Posted 15

November) [18/01/18]

A useful inventory and directory of publishing training institutions in South Africa, both for university degrees as well as short courses offered by private institutions or by book professional organizations. For degree courses it provides full contact details (of programme leaders, etc.) telephone number and email address, website, brief details of the courses/modules offered, level (NQF), admission requirements. For others it gives a short description of the nature and duration of the courses.

\section{Handbooks for authors and self-publishing}

Anon. [David Henderson] How to Apply for an ISBN Number from Zimbabwe and other African Countries.

http://www.myebook.co.za/how-to-apply-for-an-isbn-number-from-zimbabwe-and-otherafrican-countries (Posted 28 May 2017) [05/05/17]

Offers some useful advice and step-by step instructions for self-publishers in Africa that shed light on the tortuous road of obtaining that elusive ISBN, and dealing with slowgrinding national ISBN agencies.

Anon. [David Henderson] The Top 5 Mistakes South African Authors Make When Selfpublishing a Book. (Posted 22 July 2016) [05/05/17]

This helpful article takes an "honest look" at the top five mistakes made by South African authors who self-publish their book, namely poor cover designs, overpricing their e-books, placing the e-book in poor category choices, avoiding editing costs, and "being afraid of selling". 